\title{
What makes good climbing rock? A petrographic, structural, and mechanical investigation of the lower Nuttall Sandstone in the New River Gorge, West Virginia
}

Katelyn A. Huffman Olcott

West Virginia University

Follow this and additional works at: https://researchrepository.wvu.edu/etd

\section{Recommended Citation}

Olcott, Katelyn A. Huffman, "What makes good climbing rock? A petrographic, structural, and mechanical investigation of the lower Nuttall Sandstone in the New River Gorge, West Virginia" (2011). Graduate Theses, Dissertations, and Problem Reports. 3434.

https://researchrepository.wvu.edu/etd/3434

This Thesis is protected by copyright and/or related rights. It has been brought to you by the The Research Repository @WVU with permission from the rights-holder(s). You are free to use this Thesis in any way that is permitted by the copyright and related rights legislation that applies to your use. For other uses you must obtain permission from the rights-holder(s) directly, unless additional rights are indicated by a Creative Commons license in the record and/ or on the work itself. This Thesis has been accepted for inclusion in WVU Graduate Theses, Dissertations, and Problem Reports collection by an authorized administrator of The Research Repository @ WVU. For more information, please contact researchrepository@mail.wvu.edu. 


\title{
What makes good climbing rock? A petrographic, structural, and mechanical investigation of the lower Nuttall Sandstone in the New River Gorge, West Virginia
}

\author{
Katelyn A. Huffman Olcott \\ Thesis submitted to the \\ College of Arts and Sciences \\ at West Virginia University \\ in partial fulfillment of the requirements \\ for the degree of \\ Master of Science \\ in \\ Geology \\ J. Steven Kite, Ph.D., Chair \\ Kathy Bruner, Ph.D. \\ Amy Hessl, Ph.D.
}

Department of Geology and Geography

Morgantown, WV

2011

Keywords: New River Gorge, Nuttall Sandstone, Pottsville Group, Pennsylvanian Sandstone, Rock Climbing 


\begin{abstract}
What makes good climbing rock? A petrographic, structural, and mechanical investigation of the lower Nuttall Sandstone in the New River Gorge, West Virginia
\end{abstract}

\author{
Katelyn A. Huffman Olcott
}

The New River Gorge National River (NERI) consists of $300 \mathrm{~km}^{2}$ of public land including an $85 \mathrm{~km}$ length of the New River, covering parts of Summers, Raleigh, and Fayette counties in West Virginia (National Park Service, 2006). NERI is known for world class rock climbing because the Pennsylvanian lower Nuttall Sandstone of the Pottsville Group forms 15 to $30 \mathrm{~m}$ high cliffs along the gorge walls, containing more than 1500 documented climbing routes. This project investigates why the lower Nuttall Sandstone in NERI creates one of the premiere climbing areas in the Eastern United States, and why the lower Nuttall Sandstone is climbed instead of other cliff-forming sandstones in the gorge. Outcrop investigations on climbed routes, including rebound hammer determinations, show the lower Nuttall Sandstone's competence, level of surface features, jointing, and bedding are controlling variables acting on climbing desirability. Ranked level of surface features assigned based on field observations is correlated with climbing grade and popularity. Thin sections sampled from the lower Nuttall Sandstone and other sandstones document petrology as it affects rock competence.

The most desirable stratigraphic interval for expert climbers is a 15 to $20 \mathrm{~m}$ interval in the lower Nuttall Sandstone composed of homogenous quartz arenite that lacks partings along bedding planes. Throughout NERI, a basal conglomerate in the lower Nuttall Sandstone and an underlying shale unit are less mechanically strong and less resistant to weathering than the massively bedded quartz arenite layers above. Differential erosion, combined with widely spaced vertical tectonic joints, leads to large blocks of overlying lower Nuttall Sandstone failing in a predictable pattern, creating planar cliff faces and opening joints that provide climbing appeal. Lower Nuttall Sandstone cliffs and blocks contain goethite as a secondary cement along tectonic joints, which add to the rock's resistant nature. The competence of the rock appeals to climbers because the lower Nuttall Sandstone is relatively safe for climbing. Differential weathering of sandstone behind areas with goethite cement, and weathering along bedding and other sedimentary structures have created surface features that increase climbing desirability. Other cliff-forming New River Group sandstones in NERI have not been widely developed for expert climbing because they exhibit more heterogeneity and are more thinly bedded, making them less challenging for expert climbers. 


\section{ACKNOWLEDGEMENTS}

I owe so many my sincere thanks and gratitude for contributing to my thesis. It truly takes a village to raise a grad student. First and foremost, thanks to all of the folks at the National Park Service for funding my GRA and summer research and for dreaming up this project in the first place. Thanks to the Graduate Student Research Fund for helping me buy equipment and thin sections. Thanks to the Roy Sites Memorial Scholarship for funding my research and trip to G.S.A.

Thanks you, Dr. Kite, for being my fearless advisor, for all the fun days in the field, and for all of the guidance on my project. Thank you to my committee, specifically to Dr. Bruner for helping me with my thin sections and being so supportive, and to Dr. Hessl for bringing climbing expertise and scientific perspective to my project. Thank you Dr. Blake at the West Virginia Geologic and Economic Survey for helping me brainstorm about the Nuttall Sandstone's origin and for providing me thin sections. Thank you Chris Howard and Dan Harris for helping me with my point counts. Thank you John Moore, Dr. Lang, and Dr. Weislogel for helping me identify minerals. Thank you Dr. Vesper for letting me use chemicals. Thank you Dr. Kammer for helping me with my statistical methods and for helping me get funding through the Graduate Student Research Fund. Many thanks to Tom Medvick and Terracon for first of all, knowing what a Schmidt Hammer is, and second of all, letting me borrow one! Thanks, Travis Warner, for letting me borrow thin section stains and thanks to Dr. Smosna for teaching me how to use the rock saw and letting me use your microscope. Thanks to Terry Ryan for running my XRD samples at the National Energy and Technology Lab. Thanks to Dr. Sharma for helping me with isotope work. Thanks Dr. Knapp from Washington and Lee for helping me brainstorm about goethite. Thanks to Dr. Carroll of the chemistry department for working with me on the 
SEM/EDX. Thanks to my whole family for supporting my husband Kyle and me while we are back in school. Thank you Kyle (and Flash and Gonzo and Opie) for being my support system! I love you all dearly. 


\section{Table of Contents}

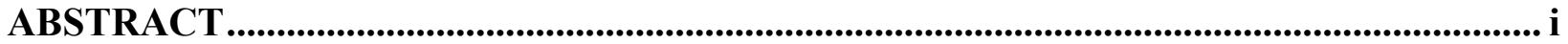

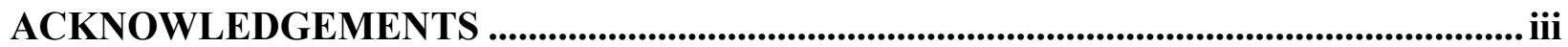

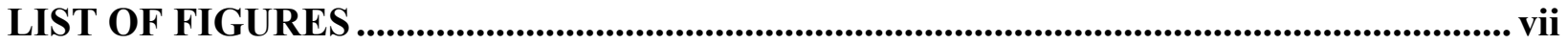

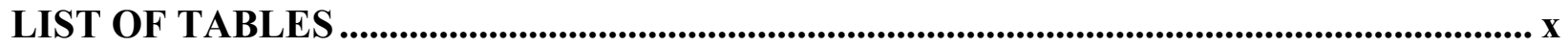

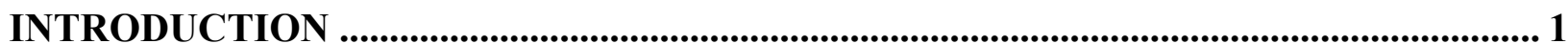

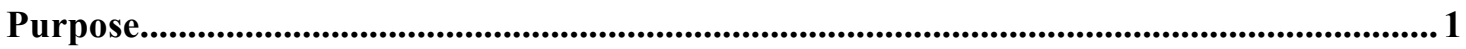

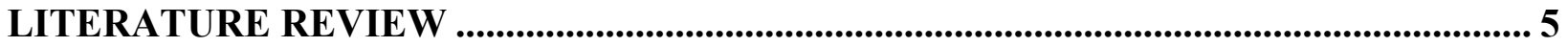

Evaluation of Rock Qualities Desirable for Climbing ......................................................5

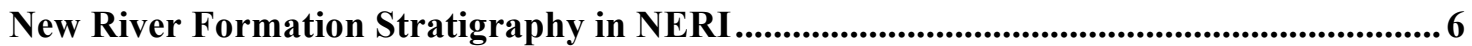

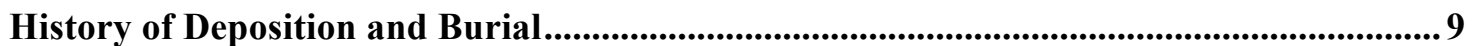

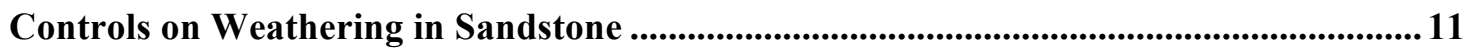

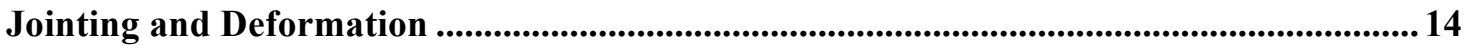

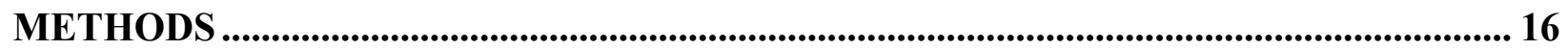

Outcrop Investigations of the Lower Nuttall Sandstone and other New River Formation

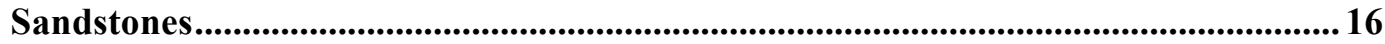

Statistical Analysis of Observed Data ......................................................................................... 24

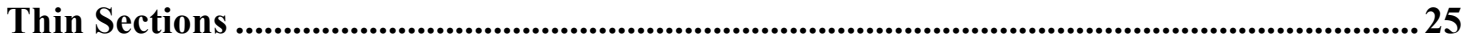

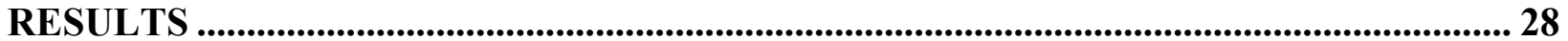

General Description of Lower Nuttall Sandstone in NERI................................................28

Outcrop Investigations of Lower Nuttall and Other New River Formation Sandstones.. 35

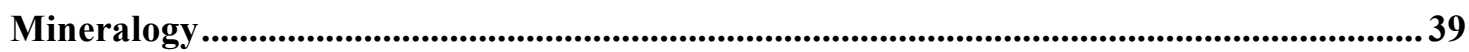

Statistical Analysis of Observed Data ............................................................................................. 48 
DISCUSSION

Interpretation of Outcrop Investigations of Lower Nuttall Sandstone and New River Formation Sandstones and Comparison to Climbing Literature ....................................................51

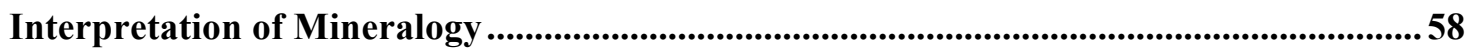

Origin of Minerals in Lower Nuttall Sandstone 58

Analysis of Primary and Secondary Cement in Lower Nuttall Sandstone and Comparison of

Goethite to Case Hardening and Concretions .......

Analysis and Comparison of Minerology and Properties of Sandstones from Thin Sections

Analysis of Statistical Results 65

CONCLUSIONS 68

Why the Lower Nuttall Sandstone is More Desirable for Climbing than other New River Sandstones 68

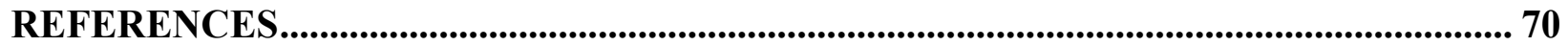

Appendix 1: Project Collaborator Clark's (2010) Methodology for Site Selection ............... 78

Appendix 2: Summary of Data Collected in Field with Outcrop Checklist and Schmidt

Hammer 83

Appendix 3: Method for Schmidt Hammer, used with permission from ASTM. 85 


\section{LIST OF FIGURES}

Figure 1: Diamond Point area and lower Nuttall Sandstone cliffs as seen from Kaymoor

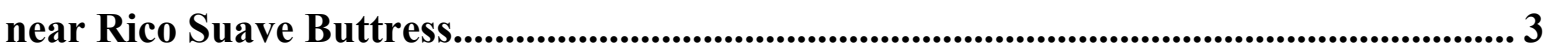

Figure 2: Map of study area highlighting climbed areas, used with permission from Clark (2010).

Figure 3: Generalized stratigraphic column, used with permission from Korus (2002)........ 9

Figure 4: Compressive strength charts for Schmidt hammer, used with permission from Forney Inc. 19

Figure 5: Map of study area showing sampling locations for thin sections in green, locations for Schmidt hammer readings in red, and studied climbed sites in blue. Fayetteville labeled for reference.

Figure 6: Stratigraphic column of lower Nuttall Sandstone interval and bounding units with thickness in meters and width indicating relative weathering profile of rock..... 31

Figure 7: Cross section view of area with goethite in secondary pores coating sandstone block at Junkyard Wall.

Figure 8: Basal conglomerate and shale at Endless Wall.

Figure 9: 2 m section of lower Nuttall Sandstone above basal conglomerate that is often crossbedded and contains obvious bedding partings.

Figure 10: Climbed outcrop on Endless Wall that lacks pronounced bedding partings and has goethite in secondary pores on face.

Figure 11: Weathering of conglomeratic lenses creating "Huecos" in Bridge Area. 34

Figure 12: Massively bedded middle unit of lower Nuttall Sandstone with overhang in thinly bedded top unit at Endless Wall. 
Figure 13: Pete Clark examining a tectonic joint that is popular for climbing at Fern

Buttress.

Figure 14: Variable bedding in the upper Raleigh Sandstone leading to small block failure.

Figure 15: Thinly bedded Guyandot sandstone at climbed location below Bridge Buttress.

Figure 16: SEM/EDX spectrum of secondary pore lacking goethite of Thin Section 1 showing elements present as different colors with standard element abbreviations.... 41

Figure 17: SEM/EDX element mapping of secondary pore without goethite of Thin Section 1 showing location of elements present in area mapped. Each element is mapped separately and labeled using standard abbreviations.

Figure 18: A. Photograph showing transect of Thin Section 1 in area without goethite analyzed for abundant elements present using SEM/EDX. B. Relative abundance of oxygen in transect. C. Relative abundance of silicon in transect. D. Graph summarizing relative abundance of elements in transect. E. Relative abundance of neodymium in transect. F. Relative abundance of arsenic in transect. 44

Figure 19: Images of element mapping using SEM/EDX on area of Thin Section 1 with goethite in secondary pore. The first image is the area mapped, and the rest of the image show specific element maps with elements abbreviated using standard abbreviation. 45

Figure 20: Large block on right is separated from bedrock outcrop by an expanded joint at Kaymoor. 56 
Figure 21: Weathering has caused partial flaking of are with goethite in secondary pores, creating climbing holds. Notice quarter for scale.

Figure 22: Differential failure of blocks below thinly bedded top section at Bridge Buttress. 


\section{LIST OF TABLES}

Table 1: Interpretation of petrology of thin sections of upper and lower Nuttall Sandstone members from $70 \mathrm{~km}$ north of Fayetteville at intersection of I-79 and US-19, used with

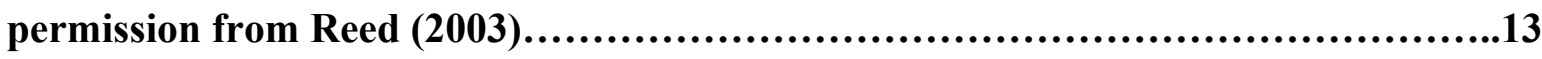

Table 2: Field data collection checklist.......................................................21

Table 3: Summary of number of measured cliff face and joint orientations compared to known joint orientations in the area of the New River Gorge...........................22

Table 4: Corrected average Schmidt hammer readings at places of interest................23

Table 5: NAD 1983 UTM Zone 17N coordinates of thin section sampling locations........27

Table 6: Thin section point-count results from New River Group sandstones in and around NERI..........................................................................................46

Table 7: XRD/XRF results with \% weight of minerals in Thin Section......................47

Table 8: Statistical results of variable correlation with $p$-values $>0.3$ reported as such and $p$ values $<0.03$ reported as actual values. Significant values or $p$-values $<0.05$

bolded. .50 


\section{INTRODUCTION}

\section{Purpose}

Bruce Burgin (1986), writing in Climbing Magazine, described the New River Gorge as an area that was nearly virgin, as it had seen very few climbers. Since then, the New River Gorge National River (NERI) (Figure 1), which is managed by the National Park Service (NPS), has developed into one of the premiere climbing areas in the Eastern United States (Williams 2010). This climbing popularity speaks to the unique climbing resources in the gorge, but as in many popular natural areas, concern of potential overuse and resulting degradation of resources and the need for sound management practices are salient issues. Previously, the unique geological aspects of the area that have led to its popularity, such as the lower Nuttall Sandstone cliffs that line its walls, have never been examined in detail, although these aspects should be considered as NPS management practices are developed for major climbing areas in NERI (Figure 2).

This project provides a geological framework for a larger project that seeks to investigate the impacts of visitor use on cliff-face ecology in the New River Gorge, specifically related to biodiversity, so that a cliff management plan can be developed. The project is a collaborative effort between the West Virginia University (WVU) Department of Geography and Geology, the WVU Recreation, Parks and Tourism Resources Program in the Division of Forestry, and the National Park Service (NPS). The overall project is based on a similar investigation in Shenandoah National Park (National Park Service 2004). The Shenandoah project sought to develop and implement a cliff management plan for an area in which the National Park Service was concerned about overuse by hikers and climbers and the resulting degradation of soils and rare plant and animal species. The Shenandoah project mapped bedrock geology and considered soils, but did not document specific qualities of rocks that affect their use in recreation. In the 
New River Gorge, the National Park Service is concerned with over use from climbing, and for this reason it is particularly important to examine why the rocks are desirable for climbing. From this information, the NPS may be able to predict areas that have not been developed for climbing but are at risk because they may become attractive to climbers. This type of analysis of a rock unit to assess its recreation value has not been widespread.

Specifically, this research project investigates the properties of the lower Nuttall Sandstone, the most commonly climbed bedrock unit in the New River Gorge, that make it desirable for climbing. According to Filer and Kleinschmidt (1987), properties of climbing rock that contribute to climbing popularity are mainly related to competence, which is affected by mineralogical composition, weathering, cementation, secondary cementation, jointing, and block stability. Climbing popularity is also related to rock features such as bedding thickness, sedimentary structures, and joints, which are products of deposition or deformation, and affect the ease or difficulty of a climb (Filer and Kleinschmidt 1987). By documenting such features in the lower Nuttall Sandstone and other cliff forming sandstones in NERI, it is possible to determine the controlling factors on why certain outcrops are climbed, as well as climber's preferences. 


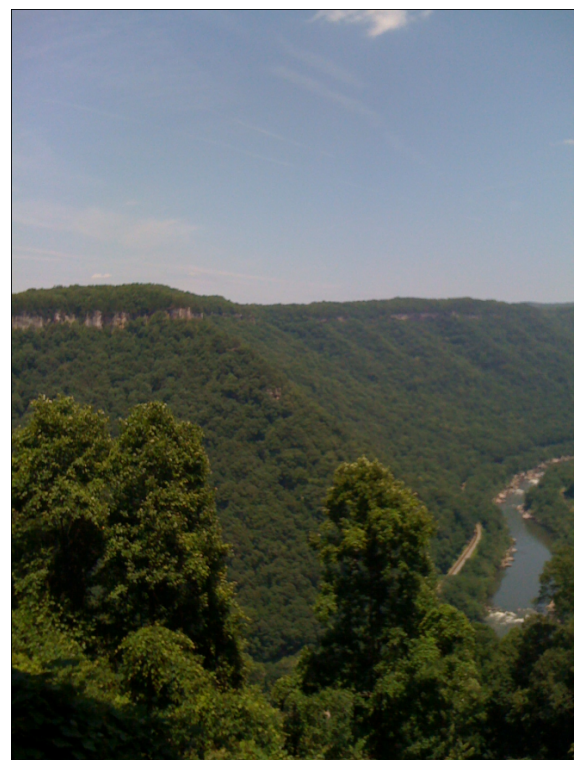

Figure 1: Diamond Point area and lower Nuttall Sandstone cliffs as seen from Kaymoor near Rico Suave Buttress. 


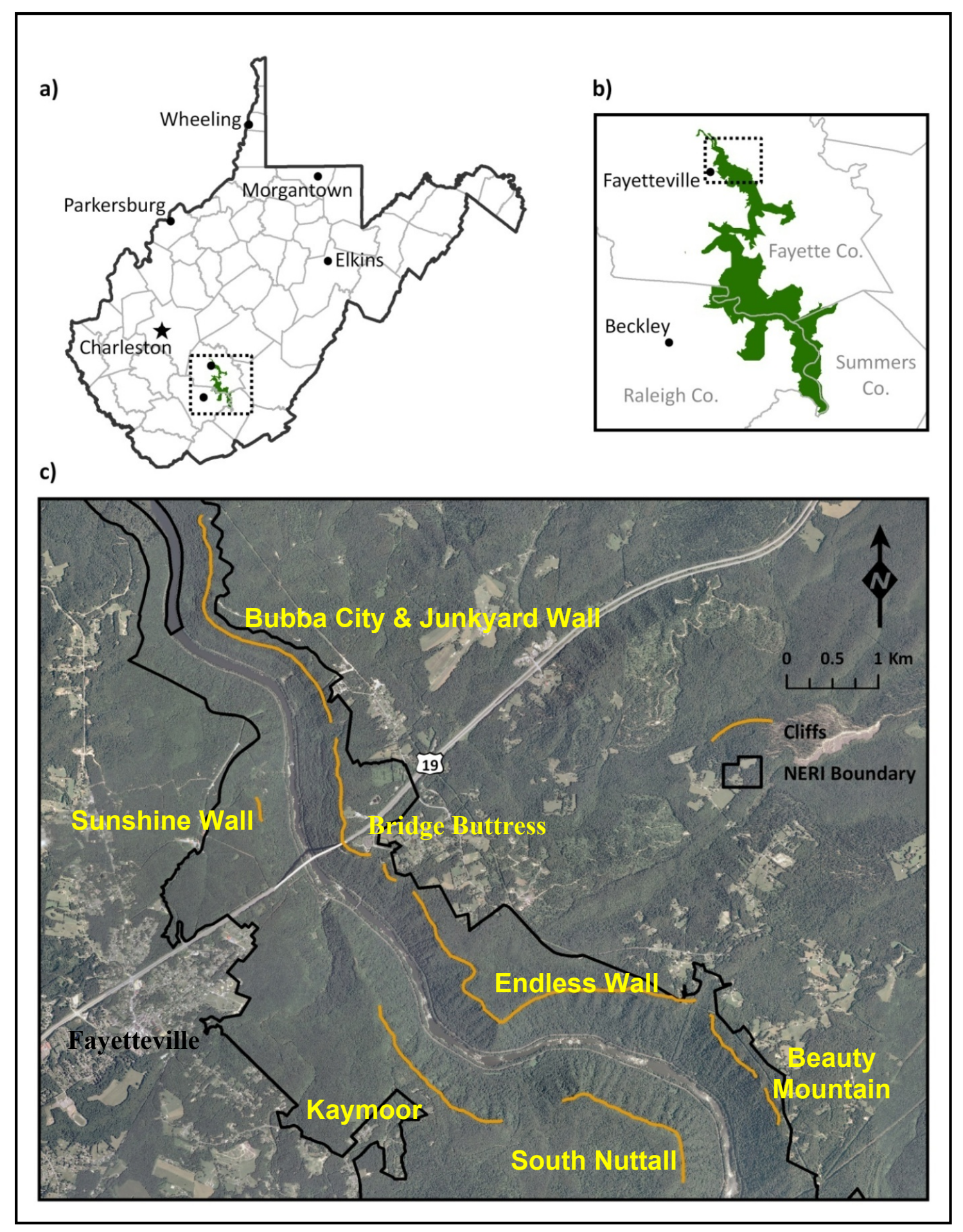

Figure 2: Map of study area highlighting climbed areas, used with permission from Clark (2010). 


\section{LITERATURE REVIEW}

\section{Evaluation of Rock Qualities Desirable for Climbing}

Several properties of frequently climbed rocks make them desirable for climbing. The most obvious quality is the ability to form a cliff, so all attributes necessary for a cliff to develop must be present, such as incision, presence of a competent and thick interval of rock, scarcity of vegetation, et cetera. Filer and Kleinschmidt (1987) state that rock composition and type are important factors when considering the geology of a climbed formation. They establish rock competence and unique surface features as the two most important bedrock qualities controlled by deposition and composition, but these are also controlled by diagenesis, deformation, and weathering. They also note granite and well-cemented sandstone are two commonly climbed rock types. Filer and Kleinschmidt (1987) identify specific qualities that affect rock competence; for example, resistant layers present desirable climbing opportunities by providing such features as corners, ledges, and roofs. Weathering can lead to surface cavities that are great hand and foot holds, so long as weathering is not to the point of affecting competence, and primary features, such as crossbedding, or secondary weathering patterns, can either provide desirable hand and foot holds or undermine overall rock competence (Filer and Kleinschmidt 1987). Cementation, recrystallization, and rock texture control how bedrock breaks and weathers, and lead to different surface features that may affect climbing suitability, and bedding surfaces can also be used in climbing techniques as space between beds provides hand and foot holds as long as partings do not compromise rock stability (Filer and Kleinschmidt 1987). Fractures and how the rock adjacent to fractures weathers are climbing considerations; fractures can open or enlarge due to 
weathering or pressure release related to valley incision, thereby providing hand and foot holds (Filer and Kleinschmidt 1987). Two other factors are important to consider as well; presence of groundwater seeps, as wet rock is not good for climbing, and ease of accessibility of climbs. Using the general qualities Filer and Kleinschmidt (1987) outlined, the processes affecting a rock's value to climbing are related to three general and interrelated categories: deposition and burial, composition and weathering, and jointing and deformation. Using these categories and their related qualities, rock can be evaluated to determine its value to climbing.

\section{New River Formation Stratigraphy in NERI}

There are seven rock formations in the New River Gorge (Lessing 1986). In NERI specifically, there are two formations exposed on the gorge walls; the Pocahontas Formation and the New River Formation, both of which are in the Pottsville Group of the Pennsylvanian Period (Figure 3) (Lessing 1986). The walls of NERI are dominated by the New River Formation, as the older Pocahontas Formation is just beginning to be exposed by the New River as it cuts down. Thus, the New Formation is of particular interest. The New River Formation is part of a sequence of coal-bearing strata that record transitions from paludal to fluvial depositional environments. It is in an interval of rocks that has been described as orthoquartzites interbedded with shales, siltstones, and coal (Horne and Ferm 1978). These orthoquartzite units do not tend to be widespread in the whole basin, but age-equivalent units of similar lithology occur in other areas, such as the Lee Formation in Eastern Kentucky (Horne and Ferm 1978).

The Nuttall Sandstone is the uppermost member of the New River Formation in the NERI and nearby areas (Figure 3). The upper member is the cap rock and the lower member is the most commonly climbed rock formation in NERI. In the most commonly used stratigraphic interpretation, which is based on lithostratigraphy, the lower Nuttall Sandstone's contact with the 
overlying Kanawha Formation represents the boundary between the Lower and Middle Pennsylvanian (Blake 2009). This remains the standard definition of the boundary in the geologic community (Blake 2009). Blake et al. (1998) used biostratigraphy to determine the boundary between the lower and middle Pennsylvanian occurs above the Nuttall Sandstone. Korus (2002) used biostratigraphy to determine an interval of shale and sandstone which lies above the Nuttall Sandstone is the chronostratigraphic boundary of the Lower and Middle Pennsylvanian (Figure 3).

The Nuttall Sandstone contains an upper and lower member in some areas, as is the case in NERI. The upper member is not a dominant cliff former in NERI, but the lower Nuttall Sandstone is. In the Fayette County geologic report, Hennen (1919) states the upper and lower members of the Nuttall Sandstone coalesce at Hawks Nest, West Virginia into a 53 to $61 \mathrm{~m}$ cliff, although upriver from Hawks Nest in modern day NERI, the Nuttall Sandstone has an upper and lower member, separated by 2 to $6 \mathrm{~m}$ of thinly bedded shale and 0.2 to $0.5 \mathrm{~m}$ of the Iaeger B coal bed. Hennen (1919) states the upper Nuttall Sandstone is the upper unit of the New River Formation, an interpretation that, as mentioned previously, is based largely on lithostratigraphy. Although descriptions of the Nuttall Sandstone exist in several other county reports written around the same time as Hennen (1919), they commonly differ from the descriptions in the Fayette County geological report.

Hennen (1919) states the upper Nuttall Sandstone is "heavy to current-bedded, grayishwhite, reddish-gray to brown, seldom pebbly, and forms great cliffs along the valley walls of the Kanawha, New, and Gauley Rivers, ranging from 40 to $100 \mathrm{ft}$. in height." He also states the lower Nuttall is the more prominent cliff former and describes it as being: 
“... massive to current-bedded, medium- to coarse-grained, highly siliceous, pebbly to conglomeratic, grayish-white to grayish-brown, ranging in thickness from 75 to $100 \mathrm{ft}$. in height, especially along the valley walls of the Gauley River between Swiss and Carnifex Ferry; Meadow River between latter Ferry and Miller; and New River between Gauley Bridge and Keeney Creek.”

Both the upper and lower Nuttall Sandstones have been quarried for building stone because they are very resistant (Hennen 1919). Hennen (1919) also noted Kanawha Falls, which are waterfalls near Glen Ferris in Fayette County, WV, exist as a result of the Kanawha River eroding into the coalesced upper and lower Nuttall Sandstone. Though the Nuttall is a fluvial sandstone, it is not merely a channel sandstone; it is laterally extensive as it represents a valley fill deposit (Korus et al. 2008), but its exact extent has never been mapped in detail. According to Lessing (1986), rock units in the New River Gorge were deposited horizontally in streams and swamps, and as a result of subsequent mountain building, now dip northwest at a rate of approximately $11 \mathrm{~m} / \mathrm{km}(60 \mathrm{ft} / \mathrm{mile})$. This gentle dip, although important to the overall stability of the lower Nuttall Sandstone outcrops, is negligible on an outcrop scale.

Other important cliff forming fluvial sandstones of the New River Formation in NERI are the Guyandot sandstone and the Raleigh Sandstone (Figure 3). The Guyandot Sandstone occurs between the lower Nuttall Sandstone and the Sewell Coal and is described as "more-or-less lenticular, massive to current-bedded, medium- to coarse-grained and pebbly, gray to grayishwhite" (Hennen 1919). It ranges from 15-30 meters in thickness and is a dominant cliff former in the New River Gorge, although not elsewhere (Hennen 1919). The older and stratigraphically lower Raleigh Sandstone is divided into two members. The upper and lower Raleigh are described as being similar in the area of NERI. Each member is 27-34 m thick and are described 
as being "heavy- to current-bedded, medium- to coarse-grained, micaceous to quartzitic, usually conglomeratic, grayish-white to grayish-brown" (Hennen 1919).

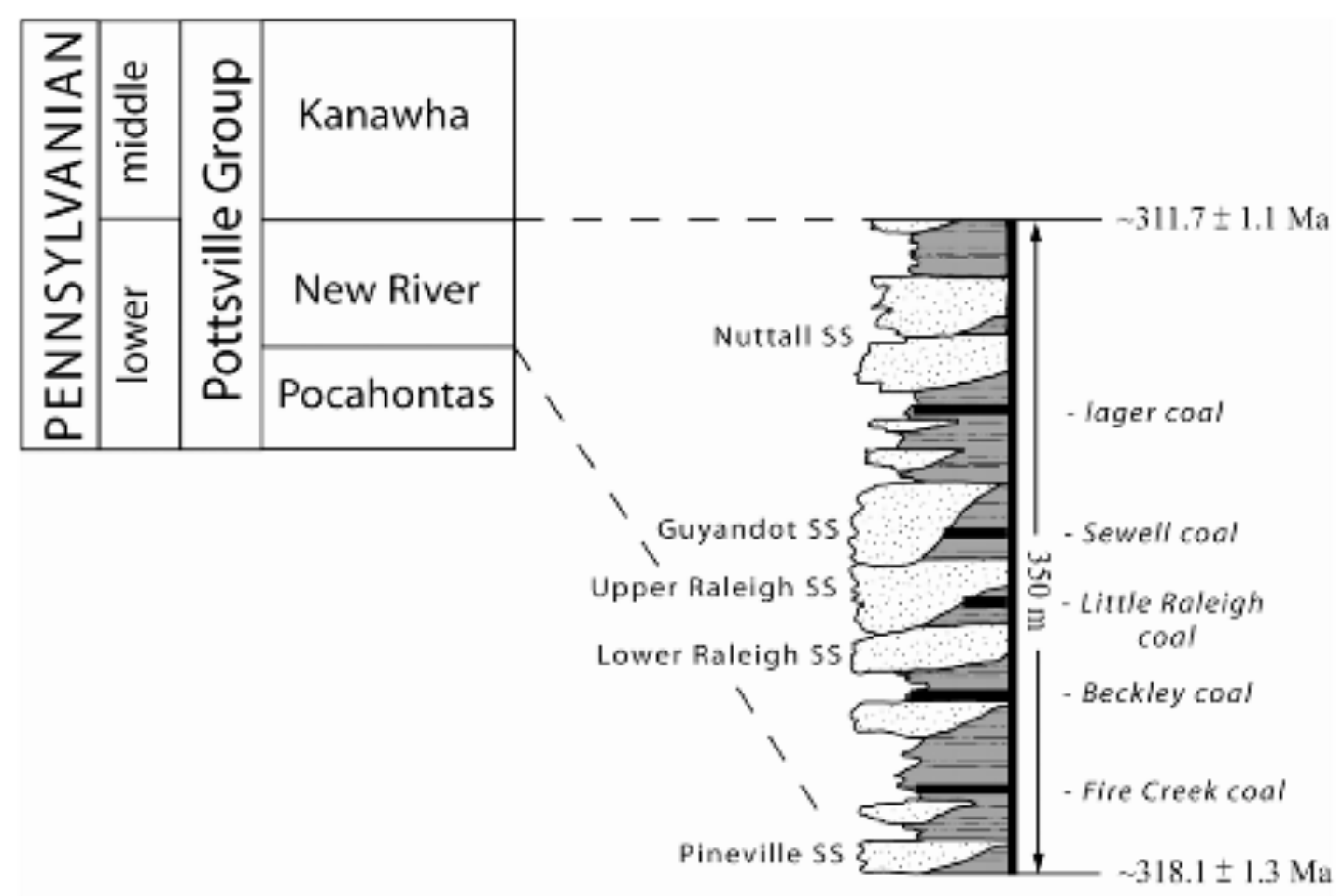

Figure 3: Generalized stratigraphic column, used with permission from Korus (2002).

\section{History of Deposition and Burial}

The depositional environment of the Nuttall Sandstone and other lower Pennsylvanian strata in the Appalachian basin has been highly contested through the years. Early on, marine interpretations dominated literature. For example, a beach-barrier model was proposed for their deposition (Horne and Ferm 1978). Cecil and Englund (1979) proposed a barrier-bar origin. More recently, interpretations of the lower Pennsylvanian orthoquartzites suggest terrestrial fluvial deposition (Greb and Chesnut 1996, Beuthin 1994, Korus et al. 2002, Wizevich 1992, Rice 1985). The interpretation of depositional environment has been used to interpret the magnitude of Pennsylvanian and Mississippian cyclothems, as well as to determine whether 
relative sea level was an effect of changing climate, glacial eustacy, or tectonic response to the Alleghenian Orogeny. Although many researchers have examined depositional environments of the Carboniferous in the Appalachians, little specific attention has been directed to the Nuttall Sandstone, which is the most commonly climbed bedrock in the New River Gorge.

The Nuttall Sandstone formed within the Pocahontas basin, part of the larger Appalachian basin, which is a structure with a complicated history affected by three separate orogenies. The Pocahontas basin is a Paleozoic foreland basin associated with the Alleghenian Orogeny (Reed et al. 2005a). It is thought to have formed as basement faults from the Grenville Orogeny were reactived as a flexural response to the rising Appalachians and to the weight of sedimentation in the basin (Donaldson and Schumacher 1982). The extent of subsidence driven by tectonic flexure or sediment loading is debated (Reed et al 2005a). After examining regional cross sections, Horne and Ferm (1978) concluded sedimentation in the Pocahontas basin occurred at the same time basement faults were active, so they cite sedimentation as the primary driver of regional subsidence during the time. Due to these changes in relative elevation of the Pocahontas basin over time and the resulting sediment accommodation space, the Nuttall Sandstone was deposited when the dominate flow direction of the fluvial system was south to southwest (Blake 2009). The climate of the time was tropical, and therefore, the Nuttall Sandstone was deposited under humid conditions (Donaldson et al. 1985). The basin is bounded by the Cincinnati arch on the west and by the Appalachian Mountains on the east (Horne and Ferm 1978). To the north, it is bounded by the Paint Creek fault; to the south, by the Warrior basin, which developed separately due to variations in direction of tectonic plate motion (Horne and Ferm 1978). Because of differences in movement along the Paint Creek fault, progradation of sedimentary layers in the Pocahontas basin occurred more rapidly in southern areas, due to 
faster subsidence (Horne and Ferm 1978). North of the basin, there was a stable platform, whereas to the south, regional subsidence proceeded southeast to northwest, causing an asymmetric pattern of sedimentation. The source of the sediments in the lower Nuttall Sandstone is debated; Rice et al. (1988) suggested the sediments were sourced from the northern highland, yet Arkle (1974) suggested its primary source was the Appalachians. The New River Formation that contains the Nuttall Sandstone was deposited over three million years (Korus 2002). It was subsequently buried by $4.4 \mathrm{~km}$ of deposits and eventually exhumed at a rate of $100 \mathrm{~m} / \mathrm{my}$ (Reed et al. 2005a).

\section{Controls on Weathering in Sandstone}

There are many controls on weathering and competence in sandstone, such as amount and type of clay mineralogy, framework grain size and composition, quartz content, and cement. For example, smectite is a shrink-swell clay; therefore, if a sandstone contains clay laminae with smectite, then the laminae will weather more readily than laminae composed of kaolinite or other clay minerals (Young et al. 2009). Young (2009) noted that, in general, the more weathered the bedrock, the weaker the bedrock; thus, amount of weathering is an important variable to consider when examining rock competence. Grain size is also important because fine-grained sandstones tend to be less mechanically strong as they weather, as does sandstone with shale interbeds and siderite cement (Young et al. 2009). Young et al. (2009) state diagenetic related quartz regrowth can also increase rock strength.

Reed et al. (2005b) suggest quartz cement in the New River Formation is a result of clay alteration; the formation was exposed to temperatures that altered smectite to illite, which releases silica that can precipitate as cement. In addition, cementation may have occurred as a result of the infusion of fluid rich with silica sourced from the hinterland or from low-grade 
metamorphism elsewhere. Reed (2003) studied basic petrology on the Nuttall Sandstone in his dissertation (Table 1), but he did not examine changes in the unit from location to location. His thin sections were from samples collected $70 \mathrm{~km}$ north of NERI near exit 57 on Interstate 79 in West Virginia. He also did not separate the upper and lower members in his analysis, although the two members can be different in grain size as well as in mineralogy. Lateral changes in the Nuttall Sandstone composition, such as changes in quartz content, have not been quantified, other than by Englund's (1979) statement that the unit to the southeast of the New River Gorge becomes "less conspicuous as a result of lateral gradation to nonresistant, micacous, and feldspathic sandstone with a relatively low quartz content of 50 to $60 \%$." 


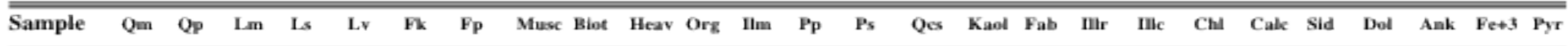

\section{Lower Pennsylvanian Sandstones}

\begin{tabular}{lllllllllllllllllllllllllllllllllll}
\hline DDS-80 & 288 & 10 & 22 & 2 & 0 & 13 & 0 & 8 & 1 & 1 & 0 & 0 & 0 & 2 & 0 & 25 & 0 & 19 & 0 & 2 & 0 & 1 & 0 & 0 & 6 & 0 \\
DDS-81 & 294 & 13 & 6 & 1 & 0 & 16 & 0 & 7 & 0 & 0 & 0 & 0 & 0 & 6 & 1 & 32 & 0 & 10 & 1 & 3 & 1 & 5 & 1 & 2 & 1 & 0 \\
DDS-82 & 327 & 21 & 2 & 0 & 0 & 9 & 0 & 6 & 1 & 0 & 0 & 0 & 0 & 2 & 3 & 21 & 0 & 2 & 0 & 0 & 1 & 0 & 0 & 1 & 4 & 0 \\
DDS-83 & 324 & 19 & 2 & 0 & 0 & 11 & 0 & 2 & 0 & 0 & 0 & 0 & 4 & 7 & 2 & 18 & 0 & 5 & 0 & 1 & 0 & 4 & 0 & 0 & 1 & 0 \\
DDS-84 & 279 & 12 & 9 & 1 & 0 & 4 & 0 & 2 & 0 & 0 & 0 & 0 & 2 & 9 & 1 & 18 & 0 & 1 & 0 & 0 & 10 & 45 & 6 & 0 & 1 & 0 \\
DDS-85 & 230 & 18 & 37 & 2 & 0 & 12 & 0 & 23 & 2 & 0 & 2 & 0 & 0 & 0 & 1 & 0 & 0 & 25 & 0 & 4 & 20 & 8 & 2 & 0 & 14 & 0 \\
DDS-87 & 269 & 16 & 28 & 0 & 0 & 11 & 0 & 16 & 2 & 0 & 0 & 0 & 0 & 0 & 0 & 0 & 0 & 24 & 0 & 3 & 15 & 6 & 0 & 0 & 10 & 0 \\
DDS-89 & 168 & 9 & 12 & 1 & 0 & 11 & 0 & 9 & 0 & 0 & 1 & 0 & 0 & 0 & 0 & 0 & 1 & 8 & 0 & 2 & 161 & 1 & 12 & 3 & 1 & 0 \\
DDS-90 & 259 & 16 & 32 & 1 & 0 & 6 & & 21 & 3 & 1 & 2 & 0 & 0 & 0 & 0 & 3 & 0 & 36 & 1 & 8 & 0 & 1 & 5 & 0 & 4 & 1 \\
DDS-91 & 257 & 20 & 27 & 2 & 0 & 8 & 0 & 18 & 1 & 0 & 0 & 0 & 0 & 0 & 0 & 10 & 0 & 29 & 0 & 3 & 1 & 3 & 10 & 2 & 9 & 0 \\
DDS-92 & 254 & 27 & 17 & 0 & 0 & 11 & 0 & 13 & 1 & 0 & 15 & 0 & 0 & 1 & 0 & 16 & 0 & 24 & 0 & 1 & 2 & 5 & 6 & 0 & 7 & 0
\end{tabular}

Qm-monocrystalline quartz; Qp-polycrystalline quartz; Lm-metamorphic rock fragments; Ls-sedimentary rock fragments; Lv-volcanic rock fragments; Fk-Kfeldspar (detrital); Fp-plagioclase feldspar (detrital); Musc-muscovite; Biot-biotite; Heav-heavy mineral; Org-organic; Ilm-ilmenite (detrital); Pp-primary porosity; Ps-secondary porosity; Qcs-authigenic quartz; Kaol-kaolinite; Fab-authigenic albite; Illr-replacement illite; Illc-illite cement; Chl-authigenic chlorite; Calc-calcite; Sid-siderite; Dol-dolomite; Ank-ankerite; Fe+3-Iron-oxide/oxyhydroxide; Pyr-pyrite

Table 1: Interpretation of petrology of thin sections of upper and lower Nuttall Sandstone members from $70 \mathrm{~km}$ north of

Fayetteville at intersection of I-79 and US-19, used with permission from Reed (2003). 


\section{Jointing and Deformation}

Fractures are important to consider in the lower Nuttall Sandstone because fractures and related features can be as important as rock strength when determining outcrop rock mass strength. Specifically, the presence of joints and fractures decrease block stability (Young 2009). As the lower Nuttall Sandstone forms cliffs at the top of a steep gorge, fracture presence and spacing are important variables to consider as they are planes of weakness that cause block failure. Joint spacing in sedimentary rocks is dependent on four specific parameters, which are bedding thickness, rock stiffness, rock tensile strength, and strain (Davis and Reynolds 1996), thus these properties are also important to consider in the lower Nuttall Sandstone. Joint spacing follows the trend of being closer together in thinner beds, and wider in thicker beds. Joints are longer in a direction perpendicular to bedding in thicker beds and therefore have larger joint shadow areas where no joints will propagate (Davis and Reynolds 1996).

Stiffness is a rock's resistance to elastic deformation. It is the elastic value represented by E in Young's Modulus and is strongly related to lithology. A stiffer lithology leads to closer joint spacing (Davis and Reynolds 1996). Sedimentary rocks, including sandstone, are not stiff lithologies, so joint spacing tends to be relatively wide. With sedimentary rocks such as shale and sandstone, joint spacing is controlled less by stiffness and more by bedding thickness. Thickbedded rock yields more widely spaced joints. Tensile strength is an even more important control on jointing than bedding thickness (Davis and Reynolds 1996). If a rock has lower tensile strength than an interbedded rock with high tensile strength, the rock with lower tensile strength could fracture first, leading to prominent joints. The relationship of strain magnitude and joint spacing is such that a rock that has undergone more stretching will have more joints that are 
more closely spaced than a rock that has undergone less stretching (Davis and Reynolds 1996). Rapid heat gain and heat loss, freeze thaw processes, and plants, can all create fractures in the rock and enlarge existing joints.

Known joint orientations obtained from outcrops in the area surrounding the New River Gorge are reported as $005^{\circ}, 010^{\circ}, 025^{\circ}, 030^{\circ}, 060^{\circ}, 070^{\circ}, 075^{\circ}, 285^{\circ}, 330^{\circ}, 340^{\circ}$, and $345^{\circ}$ (Colton et al. 1976). Known coal cleat and face cleat orientations obtained from outcrops, cores, and mines in the area of the New River Gorge indicate joint trends of $010^{\circ}$ to $020^{\circ}, 070^{\circ}$ to $090^{\circ}$, $305^{\circ}$ to $315^{\circ}$, and $310^{\circ}$ to $325^{\circ}$ (Kulander and Dean 1976). Remo (1999) found a significant correlation between the general trend of the river valley in NERI in its straight sections, as well as in meanders, to tectonic joints and other lineaments, including coal cleats. If cliffs of the lower Nuttall Sandstone are oriented with the known joint orientations they would therefore be oriented with the river and gorge, which could control the pattern of block failure. 


\section{METHODS}

\section{Outcrop Investigations of the Lower Nuttall Sandstone and other New River Formation}

\section{Sandstones}

Outcrop investigations were performed in June and July 2010 at climbed routes throughout major climbing areas in NERI to document features related to climbing. Coordinates are based on NAD 1983 and are from Clark (2010). A data sheet that included a checklist (Table 2) was developed for use at each site based on the description of geologic features important to climbing by Filer and Kleinschmidt (1987) and initial outcrop investigations. Sites were chosen based on a method developed in Clark (2010) that highlights differences in amount of use and popularity of climbing routes (Appendix 1). Clark's (2010) method is largely based on climber assigned ratings of difficulty and quality referred to as stars (Appendix 1). Whether a climb, or climbing route, was bolted, not bolted, or only a bolted anchor was noted; the type and degree of bolting indicates the dominant style of climbing used on a route. Bolted climbs contain a varied number of metal bolts used by climbers to clip gear to in a style referred to as "sport climbing." Non-bolted climbs contain no bolts and typically are climbed by placing removable gear into natural features on the rock in a style called "trad" or "traditional climbing." Climbs with anchor bolts contain two metal bolts at the top of the route that are used for a style of climbing called "top-roping" or for rappelling. Trees at the top of routes, where accessible, may also be used as anchors in top-roping.

Each climb examined was photographed using an Olympus SP-600UZ 12 megapixel wide angle digital camera with $15 \mathrm{x}$ optical zoom. Cliff orientation and crossbed orientation were measured using a Silva Ranger CL Compass. Compressive material strength of each site (Figure 4) was measured with a W-M 250 Type N Manual Rebound Hammer using the method outlined 
in ASTM D 5873-05, Standard Test Method for Determination of Rock Hardness (Appendix 3), which includes a method for obtaining a corrected average reading. It is important to note that although the method includes the word "hardness," the word is not used in the common geologic sense of the word, and therefore should be thought of as meaning "mechanical strength". The hammer was calibrated by the manufacturer prior to use, so ASTM D 5873-05 was modified because correcting for calibration was unnecessary. The lower Nuttall Sandstone is commonly mechanically stronger than the acceptable limits on the hammer, so readings were only able to be used as relative indicators of strength. Readings on the scale of the hammer have corresponding pounds per square inch and $\mathrm{kg} / \mathrm{m}^{2}$ (Figure 4). All hammer readings were taken at 0 degrees which is defined as horizontal in ASTM D 5873-05. South Nuttall climbing routes were not hammered because the hammer was not available during the initial visit and returning with tool was not undertaken due to safety concerns and difficult access. Hammer readings were taken at locations representative of the lower Nuttall Sandstone that were not part of studied climbed routes (Figure 5 and Table 4). The basal conglomerate was hammered at three locations. Areas containing goethite as a secondary cement along fractures were hammered at four locations and compared to sandstone without goethite as a secondary cement at three of those locations. An area was hammered that did have not goethite as a secondary cement at another location. The top of Diamond Point overlook, in the more thinly bedded top portion of the lower Nuttall Sandstone, was hammered, and an outcrop that had more bedding partings and rocks failing as small blocks was hammered. The Guyandot sandstone, where it is climbed below Bridge Buttress, was also hammered.

Weathering features were documented in the lower Nuttall Sandstone, and these, combined with number of significant bedding partings, presence of vertical and horizontal 
partings, leisegangen, joints, flakes, crossbedds, and other macro surface features were used to assign a climb as having a low (1), medium (2), or high (3) level of macro surface features. The underlying upper Raleigh Sandstone and Guyandot sandstone (Figure 3) were examined as well. The upper Raleigh Sandstone was examined at Grandview, West Virginia, where it is a cliff former, and bedding, surface features, and competence of rock were compared and contrasted to the lower Nuttall Sandstone elsewhere. The Guyandot sandstone outcrop was examined below the climbing area "Bridge Buttress" (Figure 2) and notes were taken comparing and contrasting bedding, surface features, and competence of the rock to the lower Nuttall Sandstone. Joint orientations measured in the field were compared to joint orientations measured from outcrops and cores reported in Colton et al. (1976) and measured from coal cleats reported in Kulander and Dean (1993). Small variation in joint orientation is expected due to the irregular nature of joints, thus a measurement within 10 degrees of a known orientation was considered significant (Table 3). Joint measurements from this study were classified as either being exactly the same as a previously reported known orientation, within 1 degree of a reported orientation, within 5 degrees of a reported orientation, or within 10 degrees of a reported orientation. 

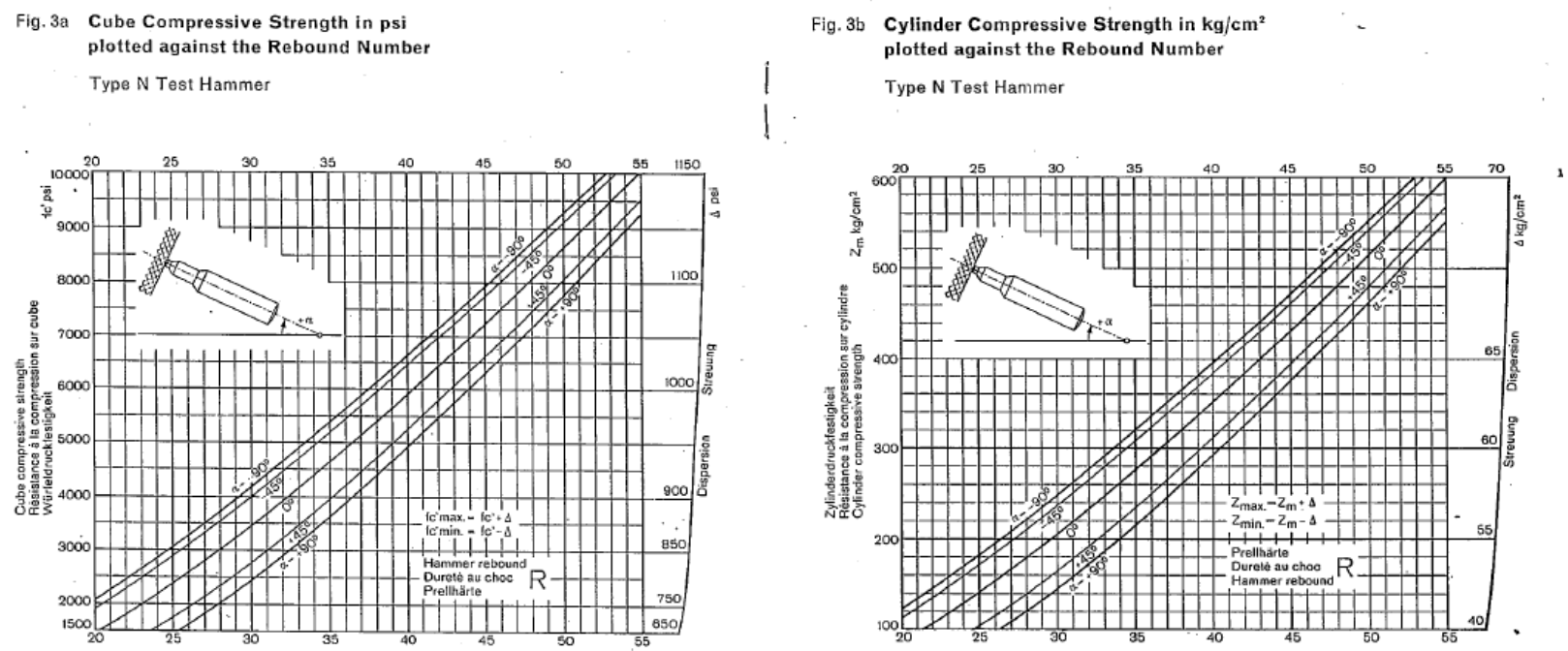

Figure 4: Compressive strength charts for Schmidt hammer, used with permission from

Forney Inc. 


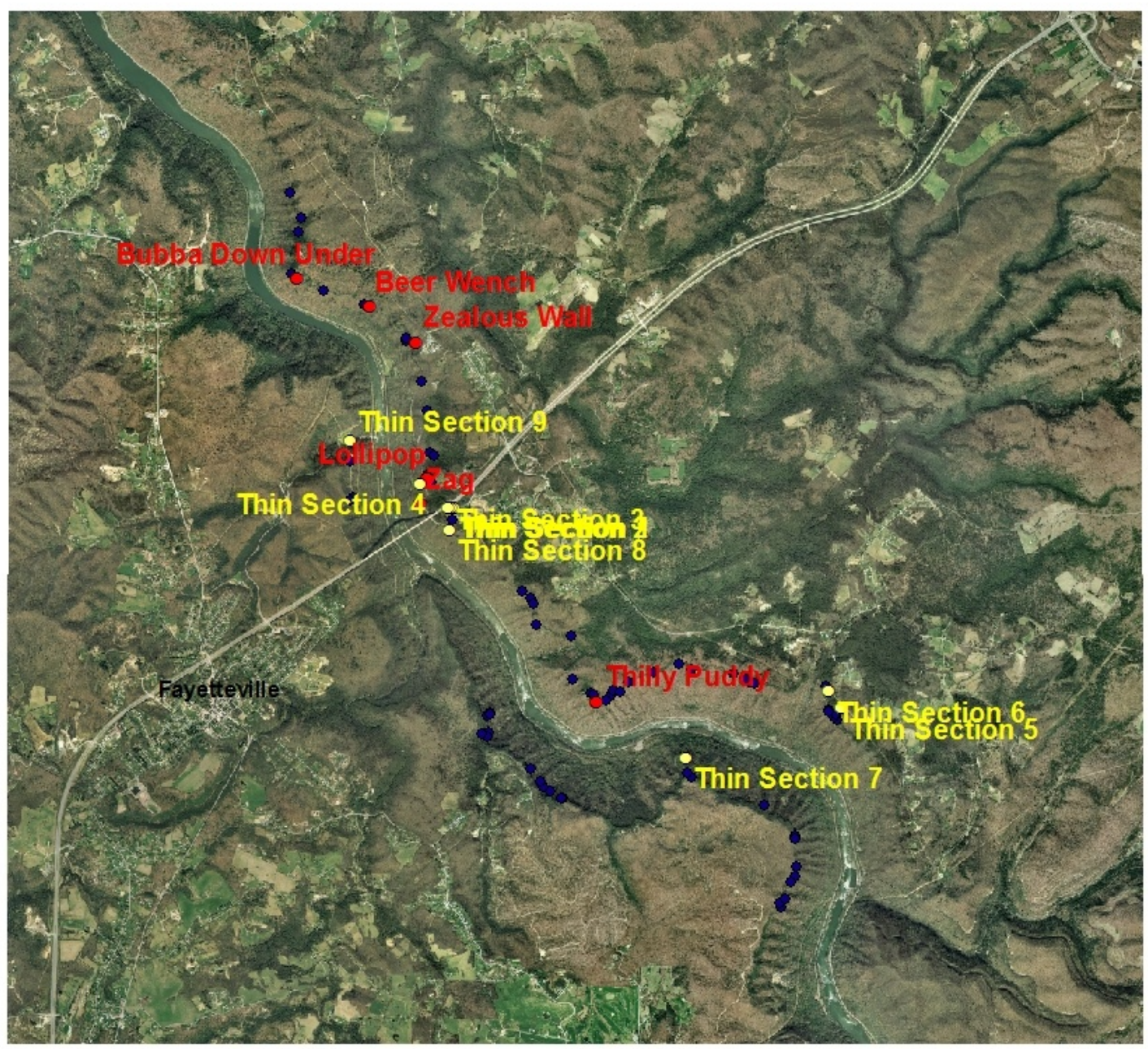

Hammered Locations Not Sampled Otherwise - Climbed Sites Inve stigated

Thin Section Locations

Figure 5: Map of study area showing sampling locations for thin sections in green, locations for Schmidt hammer readings in red, and studied climbed sites in blue. Fayetteville labeled for reference. 


\begin{tabular}{|c|c|c|c|}
\hline \multicolumn{4}{|l|}{ Field Data } \\
\hline \multicolumn{4}{|l|}{ Date: } \\
\hline \multicolumn{4}{|l|}{ Weather: } \\
\hline \multicolumn{4}{|l|}{ Photography Number: } \\
\hline \multicolumn{4}{|l|}{ Location Description/Ease of Access: } \\
\hline \multicolumn{4}{|l|}{ Cliff Face Orientation: } \\
\hline \multicolumn{4}{|l|}{ Orientation if at Corner: } \\
\hline \multicolumn{4}{|l|}{ Schmidt Hammer Reading: } \\
\hline \multicolumn{4}{|l|}{ Number of Beds: } \\
\hline \multicolumn{4}{|l|}{ Bedding Thicknesses from Bottom to Top: } \\
\hline \multicolumn{4}{|l|}{ Number of Samples Collected: } \\
\hline \multicolumn{4}{|l|}{ Grain Size: } \\
\hline \multicolumn{4}{|l|}{ Sorting: } \\
\hline \multicolumn{4}{|l|}{ Roundedness: } \\
\hline \multicolumn{4}{|l|}{$\%$ Quartz: } \\
\hline \multicolumn{4}{|l|}{ Cement: } \\
\hline Weathering Features & yes & no & \\
\hline \multicolumn{4}{|l|}{ Description: } \\
\hline Crossbedding, Imbrication, Ripples, et cetera: & yes & no & \\
\hline \multicolumn{4}{|l|}{ Description: } \\
\hline Goethite Presence and Description: & yes & no & \\
\hline \multicolumn{4}{|l|}{ Description: } \\
\hline Fossils: & yes & no & \\
\hline \multicolumn{4}{|l|}{ Description: } \\
\hline Load or Slump Structures: & yes & no & \\
\hline \multicolumn{4}{|l|}{ Description: } \\
\hline Graded Bedding: & yes & no & \\
\hline \multicolumn{4}{|l|}{ Description: } \\
\hline Erosional Surfaces: & yes & no & \\
\hline \multicolumn{4}{|l|}{ Description: } \\
\hline Clay Laminae, Flaser Bedding, et cetera: & yes & no & \\
\hline \multicolumn{4}{|l|}{ Description: } \\
\hline \multicolumn{4}{|l|}{ Block Description (Overhangs, et cetera): } \\
\hline Other Features of Note: & & & \\
\hline
\end{tabular}

\section{Table 2: Field data collection checklist.}


Measured Cliff Face and Joint Orientations Compared to Known Orientations from Bedrock and Coal Cleats

\begin{tabular}{|c|c|c|c|c|}
\hline$\#$ ex & $\#$ within $1^{\circ}$ & $\#$ within $5^{\circ}$ & $\#$ within $10^{\circ}$ & $\#>10^{\circ}$ \\
\hline 29 & 37 & 79 & 94 & \\
\hline
\end{tabular}

Table 3: Summary of number of measured cliff face and joint orientations compared to known joint orientations in the area of the New River Gorge. 


\begin{tabular}{|c|c|c|c|}
\hline $\begin{array}{l}\text { Route and/or } \\
\text { Climbing } \\
\text { Area }\end{array}$ & Lithologic Unit & $\begin{array}{l}\text { NAD } 1983 \text { UTM } \\
\text { Z17N Coordinates }\end{array}$ & $\begin{array}{l}\text { Corrected } \\
\text { Average }\end{array}$ \\
\hline $\begin{array}{l}\text { Zag at Bridge } \\
\text { Buttress }\end{array}$ & $\begin{array}{l}\text { Basal Conglomerate of } \\
\text { Lower Nuttall } \\
\text { Sandstone }\end{array}$ & $\begin{array}{l}4215166 \mathrm{~m} \mathrm{~N}, \\
492961 \mathrm{~m} \mathrm{E}\end{array}$ & 39.3 \\
\hline $\begin{array}{l}\text { Lollipop at } \\
\text { Bridge Buttress }\end{array}$ & $\begin{array}{l}\text { Geothite in Lower } \\
\text { Nuttall Sandstone }\end{array}$ & $\begin{array}{l}4213837 \mathrm{~m} \mathrm{~N}, \\
492956 \mathrm{~m} \mathrm{E} \\
\end{array}$ & 60.6 \\
\hline $\begin{array}{l}\text { Lollipop at } \\
\text { Bridge Buttress }\end{array}$ & $\begin{array}{l}\text { Lower Nuttall } \\
\text { Sandstone } \\
\end{array}$ & $\begin{array}{l}4213837 \mathrm{~m} \mathrm{~N}, \\
492956 \mathrm{~m} \mathrm{E}\end{array}$ & $\mathbf{5 7 . 0}$ \\
\hline $\begin{array}{l}\text { Beer Wench at } \\
\text { Bubba City }\end{array}$ & $\begin{array}{l}\text { Basal Conglomerate of } \\
\text { Lower Nuttall } \\
\text { Sandstone } \\
\end{array}$ & $\begin{array}{l}4215565 \mathrm{~m} \mathrm{~N}, \\
492368 \mathrm{~m} \mathrm{E}\end{array}$ & 29.4 \\
\hline $\begin{array}{l}\text { Beer Wench at } \\
\text { Bubba City }\end{array}$ & $\begin{array}{l}\text { Goethite Cement in } \\
\text { Basal Conglomerate of } \\
\text { Lower Nuttall } \\
\text { Sandstone }\end{array}$ & $\begin{array}{l}4215565 \mathrm{~m} \mathrm{~N}, \\
492368 \mathrm{~m} \mathrm{E}\end{array}$ & 50.3 \\
\hline $\begin{array}{l}\text { Bubba Down } \\
\text { Under at } \\
\text { Bubba City }\end{array}$ & $\begin{array}{l}\text { Weathered Lower } \\
\text { Nuttall Sandstone }\end{array}$ & $\begin{array}{l}4215869 \mathrm{~m} \mathrm{~N}, \\
491646 \mathrm{~m} \mathrm{E}\end{array}$ & 44.1 \\
\hline Zealous Wall & $\begin{array}{l}\text { Basal Conglomerate of } \\
\text { Lower Nuttall } \\
\text { Sandstone } \\
\end{array}$ & $\begin{array}{l}4216166 \mathrm{~m} \mathrm{~N}, \\
492861 \mathrm{~m} \mathrm{E}\end{array}$ & 33.0 \\
\hline Zealous Wall & $\begin{array}{l}\text { Goethite in Lower } \\
\text { Nuttall Sandstone }\end{array}$ & $\begin{array}{l}4216166 \mathrm{~m} \mathrm{~N}, \\
492861 \mathrm{~m} \mathrm{E}\end{array}$ & 57.4 \\
\hline Zealous Wall & $\begin{array}{l}\text { "Chossy" Lower Nuttall } \\
\text { Sandstone }\end{array}$ & $\begin{array}{l}4216166 \mathrm{~m} \mathrm{~N}, \\
492861 \mathrm{~m} \mathrm{E}\end{array}$ & 38.2 \\
\hline $\begin{array}{l}\text { Below Bridge } \\
\text { Buttress, Same } \\
\text { as Thin Section } \\
3\end{array}$ & Guyandot sandstone & $\begin{array}{l}4213525 \mathrm{~m} \mathrm{~N}, \\
493204 \mathrm{~m} \mathrm{E}\end{array}$ & 60.0 \\
\hline $\begin{array}{l}\text { Top of } \\
\text { Diamond } \\
\text { Point, Above } \\
\text { Thilly Puddy }\end{array}$ & $\begin{array}{l}\text { Thin Lower Nuttall } \\
\text { Beds at Top of Section }\end{array}$ & $\begin{array}{l}4211539 \mathrm{~m} \mathrm{~N}, \\
494656 \mathrm{~m} \mathrm{E}\end{array}$ & 54.8 \\
\hline
\end{tabular}

Table 4: Corrected average Schmidt hammer readings at places of interest. 


\section{Statistical Analysis of Observed Data}

Three statistical classes of variables were collected in this study: binary, measured, and ranked. Binary variables included joints, liesegangen, and crossbeds, and were recorded as present (1) or absent (0). Values obtained by direct measurement included cliff face orientation, Schmidt hammer material strength measurement, and height of climb. Ranked variables included star value of climb from 1 to 4 , grade/difficulty of climb from 6 to 13 , grade/difficulty of climb from 1 to 4, use of climb from 1 to 4 , and extent of surface features from 1 to 3 . As a rule, ranked data should only be correlated with ranked data. This rule presented a problem when comparing measured data that had a wide range, such as orientation. For example, a 5 degree difference in reality may be negligible, yet statistically, its influence can be large. Therefore, orientation was converted to a ranked class, where 0-10 degrees was classified as 1,11 to 20 degrees as 2,21 to 30 degrees as 3 , and so on and so forth up to 180 degrees. Since measured material strength ranged from 47 to 61 , it was not rescaled, but instead was used like a ranked variable by using $1=47,2=48$, and so on through 61 . Converting measured data to ordinal data for analysis is a common statistical method (personal communication with Dr. T Kammer April 2011, Davis 2002). It is most useful in situations where an examination of relationships of variables is desired, but a Pearsonian product-moment correlation coefficient is inappropriate (Davis 2002).

All ranked and rank-converted data were analyzed in Paleontological Statistical Software (PAST) in July 2010, using the correlation tool and the Spearman's rank coefficient, which is a non-parametric coefficient that indicates associates between ranked variables that are not necessarily linear (Spearman 1904, Davis 2002). Performing correlation using the Spearman's rank coefficient is a commonly used method for analyzing ranked data (Davis 2002, personal communication with Dr. T. Kammer April 2011). The method involves considering variables as 
paired $\mathrm{x}$ and $\mathrm{y}$ values and ranking each measurement by magnitude from 1 to $\mathrm{n}$, where $\mathrm{n}$ is the sample size (Davis 2002). Then, the following equation is evaluated for the comparison of the two variables: $\mathrm{rs}=1-\left(\left(6\left(\sum_{\mathrm{i}=1}^{\mathrm{n}}\left(\mathrm{R}\left(\mathrm{x}_{\mathrm{i}}\right)-\mathrm{R}\left(\mathrm{y}_{\mathrm{i}}\right)\right)^{2}\right)\right) /\left(\mathrm{n}\left(\mathrm{n}^{2}-1\right)\right)\right)$, where $\mathrm{x}_{\mathrm{i}}$ and $\mathrm{y}_{\mathrm{i}}$ are each observation of variables and $\mathrm{n}$ is sample size (Davis 2002). Rs values vary from 1 to -1 , where 1 indicates a perfect positive correlation between variables and -1 represents a perfect negative correlation between variables, and 0 implies no correlation between variables (Davis 2002). The null hypothesis is that $r s=0$, or that there is no correlation between variables (Davis 2002). Corresponding p-values can be looked up in a reference table (Davis 2002). A p-value represents the probability that a relationship exists by chance (Davis 2002). A common value that is considered statistically significant is $p<0.05$, which was used in this study (Davis 2002). When $\mathrm{p}<0.05$, the null hypothesis is rejected in favor of the alternative hypothesis that the variables are correlated (Davis 2002).

Correlation was performed on all climbs measured, but also on sub-groups of the data set separated by type of bolting present to reflect differences between groups. For example, a correlation of surface features and stars was done on all climbs, on bolted climbs, on non-bolted climbs, on anchor bolted climbs, on bolted and non-bolted climbs, on bolted and anchor bolted climbs, and on non-bolted and anchor bolted climbs. To be statistically valid, binary data were only compared to binary data in PAST, using the Jaccard coefficient, but were not found to be significantly correlated and are not included in discussion.

\section{Thin Sections}

A total of nine oriented samples were collected for thin sections in July 2010 (Table 5). A rock hammer was used to break off the surface of cliff faces so unexposed rock could be collected. Originally, samples were to be collected at climbed sites of various types throughout 
the study area, but it became apparent that samples could not be collected at climbed areas without negatively affecting climbing routes, so five samples were taken adjacent to climbed routes. Based on hand sample analyses, there does not appear to be large scale changes in the mineralogy of the massively bedded section of the lower Nuttall Sandstone that receives so much climbing attention, so the five samples taken should reflect the mineralogy of the lower Nuttall Sandstone in the field area. To be sure that samples accurately reflected any variation in mineralogy, the samples taken were on opposites sides of the river and at opposite ends of the study area: two from the northwest end of the study area on opposites sides of the river, two on the southeast end of the study area on opposite sides of the river, and one in the middle of the study area with goethite as a secondary cement along a fracture (Figure 5 and Table 5). Four other samples were taken: one in the basal conglomerate, one in the top and more thinly bedded interval of the lower Nuttall Sandstone, one in the upper Raleigh Sandstone, and one in the Guyandot sandstone (Figure 5 and Table 5). The orientation of each sample was marked before removal from the outcrop, and that orientation was carefully transferred to each thin section.

Thin sections were prepared in August 2010 by the University of Iowa Petrographic Facilities on 1x2 inch standard glass slides stained with blue epoxy to indicate porosity and left uncovered. A feldspar stain was attempted on Thin Section 1 by the University of Iowa Petrographic Facilities, but showed no feldspars. Hence, Thin Sections 2 to 9 were not stained for feldspars. Thin Sections 10 and 11 are from the upper and lower Nuttall Sandstone members, respectively, and were donated from the West Virginia Economic and Geologic Survey and are the very same thin sections Reed (2003) examined (Table 1) from $70 \mathrm{~km}$ north of NERI (Table 5). Carbonate staining on the bottom half of each of the eleven thin sections was performed at WVU using the standard alzarin red and potassium ferrocyanide staining method in September 
2010. Thin sections were analyzed for mineralogy using 300 point counts of randomly selected grains using a Nikon Labaphot polarizing microscope at the WVU Department of Geology and Geography in October 2010. Minerals present and whether pores were primary or secondary were identified by their distinguishing characteristics, using Pettijohn et al. (1987) as a reference. Scanning Electron Microscope/Energy Dispersive using X-Ray (SEM-EDX) analysis was performed on Thin Section 1 in the WVU shared Environmental SEM facility in October 2010. A sample of lower Nuttall Sandstone containing goethite as a secondary cement along a fracture was powdered and analyzed by $\mathrm{x}$-ray diffraction (XRD) combined with $\mathrm{x}$-ray florescence (XRF) at the Department of Energy's National Energy Technology Lab in Morgantown during October 2010. A sample each of overlying and underlying shales, as well as a sample of lower Nuttall Sandstone without goethite as a secondary cement, were powdered in the WVU Department of Geology and Geography and analyzed by XRD in the WVU Department of Physics during November 2010.

\begin{tabular}{|l|l|l|}
\hline Sample Number & Northing & Easting \\
\hline Thin Section 1 & $4213528 \mathrm{~m}$ & $493266 \mathrm{~m}$ \\
\hline Thin Section 2 & $4213528 \mathrm{~m}$ & $493240 \mathrm{~m}$ \\
\hline Thin Section 3 & $4213525 \mathrm{~m}$ & $493204 \mathrm{~m}$ \\
\hline Thin Section 4 & $4213769 \mathrm{~m}$ & $492920 \mathrm{~m}$ \\
\hline Thin Section 5 & $4211476 \mathrm{~m}$ & $497216 \mathrm{~m}$ \\
\hline Thin Section 6 & $4211646 \mathrm{~m}$ & $497084 \mathrm{~m}$ \\
\hline Thin Section 7 & $4210972 \mathrm{~m}$ & $495627 \mathrm{~m}$ \\
\hline Thin Section 8 & $4213294 \mathrm{~m}$ & $493224 \mathrm{~m}$ \\
\hline Thin Section 9 & $4214209 \mathrm{~m}$ & $492210 \mathrm{~m}$ \\
\hline Thin Section 10 & $4274550 \mathrm{~m}$ & $521344 \mathrm{~m}$ \\
\hline Thin Section 11 & $4274550 \mathrm{~m}$ & $521344 \mathrm{~m}$ \\
\hline
\end{tabular}

Table 5: NAD 1983 UTM Zone 17N coordinates of thin section sampling locations. 


\section{RESULTS}

\section{General Description of Lower Nuttall Sandstone in NERI}

The walls of the New River Gorge in NERI have $>250 \mathrm{~m}$ of relief above the river and include many linear km of Pennsylvanian sandstone cliffs (NPS 2006). The cap rock in NERI near Fayetteville is generally the variable upper Nuttall Sandstone, which is exposed in many natural outcrops and roadcuts near the gorge; however, the more uniformly resistant lower Nuttall Sandstone is the dominant cliff former. Climbing is concentrated in the northwest corner of the New River Gorge and because of the dip of the rock, to the southwest stratigraphically lower sandstones line the gorge walls and the lower Nuttall Sandstone has been eroded away. Notable cliff formers in the southwest area of NERI are the underlying upper Raleigh Sandstone, Guyandot sandstone, and Pineville Sandstone, none of which are extensively climbed. The landscape in NERI was extensively timbered and mined in the past, so a network of roads runs along its walls. These roads present an interesting variable; many were not maintained and are difficult to detect now, making it difficult to determine if some outcrops in the gorge are natural or manmade. The roads provide access to and reveal many of the sandstones that would otherwise be hidden by trees and vegetation. The extent that mining activity affected the cliffs by blasting or other practices is largely unknown and may remain so due to lack of written records.

The lower Nuttall Sandstone in NERI is 24 to $30 \mathrm{~m}$ thick, may contain a basal conglomerate of 0.2 to $1.2 \mathrm{~m}$, and is underlain by a variable amount of shale (Figure 6). Goethite occurs as a secondary cement in host rock adjacent to joint surfaces (Figure 7). The coarsegrained basal conglomerate, which contains very coarse sand, granules, and pebbles up to $20 \mathrm{~mm}$ in diameter, is pinkish white (5YR 8/1), with framework grains that are sub-rounded and medium 
sorted, and is 80 to $90 \%$ quartz. In rare locations, it has shaley interbeds or local coal lenses (Figure 8). Above the conglomerate, pebbles become rarer, although pebbles may occur in crossbeds or in 0.01 to $0.1 \mathrm{~m}$ thick conglomeratic lenses. A $2 \mathrm{~m}$ thick section above the basal conglomerate is comprised of 0.1 to $0.4 \mathrm{~m}$ thick beds that are typically crossbedded (Figure 9). Beds in this section are typically composed of medium grained sandstone that is moderately to well sorted, sub-angular to sub-rounded, and $>90 \%$ quartz. The sandstone is normally light grey $(7 / \mathrm{N} 7)$ to white $(8 / \mathrm{N} 8)$ and pinkish white $(5 \mathrm{YR} 8 / 1)$ but varies depending on the presence or absence of yellowish brown (10R 4/4) to reddish black (10R 2.5/1) goethite as a secondary cement. Partings between bedding are not extremely pronounced.

A 15 to $22 \mathrm{~m}$ section of massively bedded medium grained sandstone that lacks continuous bedding partings or obvious sedimentary structures occurs above the crossbedded layers (Figure 10). It is light grey (7/N7) to white (8/N8) and pinkish white (5YR 8/1) in color. Framework grains are well sorted, sub-angular to sub-rounded, and are $>90 \%$ quartz. In general, this thick stratigraphic interval is competent and lacks many large primary features, although in places horizontal partings are present and may be related to mud drapes or noncontinuous bedding. Near the base of this interval, features climbers refer to as "heucos" (Figure 11) may occur. In many cases huecos appear to be local conglomeratic channels that have eroded faster than surrounding rock. Above this massively bedded interval, a 2 to $5 \mathrm{~m}$ section of medium grained sandstone with 0.2 to $1 \mathrm{~m}$ beds with significant bedding partings forms the top of the lower Nuttall Sandstone and is light grey $(7 / \mathrm{N} 7)$ to white $(8 / \mathrm{N} 8)$ and pinkish white $(5 \mathrm{YR}$ 8/1) in color (Figure 12). The interval is moderately to well sorted, has framework grains that are sub-angular to sub-rounded, and is $>90 \%$ quartz. 
The general trend of the river in NERI is southeast to northwest, therefore, lower Nuttall Sandstone cliff orientation or aspect varies with block failure and as the river meanders, but in general, cliffs located on the north side of the river face southwest and cliffs on the south side of the river face northeast. This changing orientation has an effect on solar radiation received, which can affect weathering. The northeast facing cliffs receive more effective moisture. 


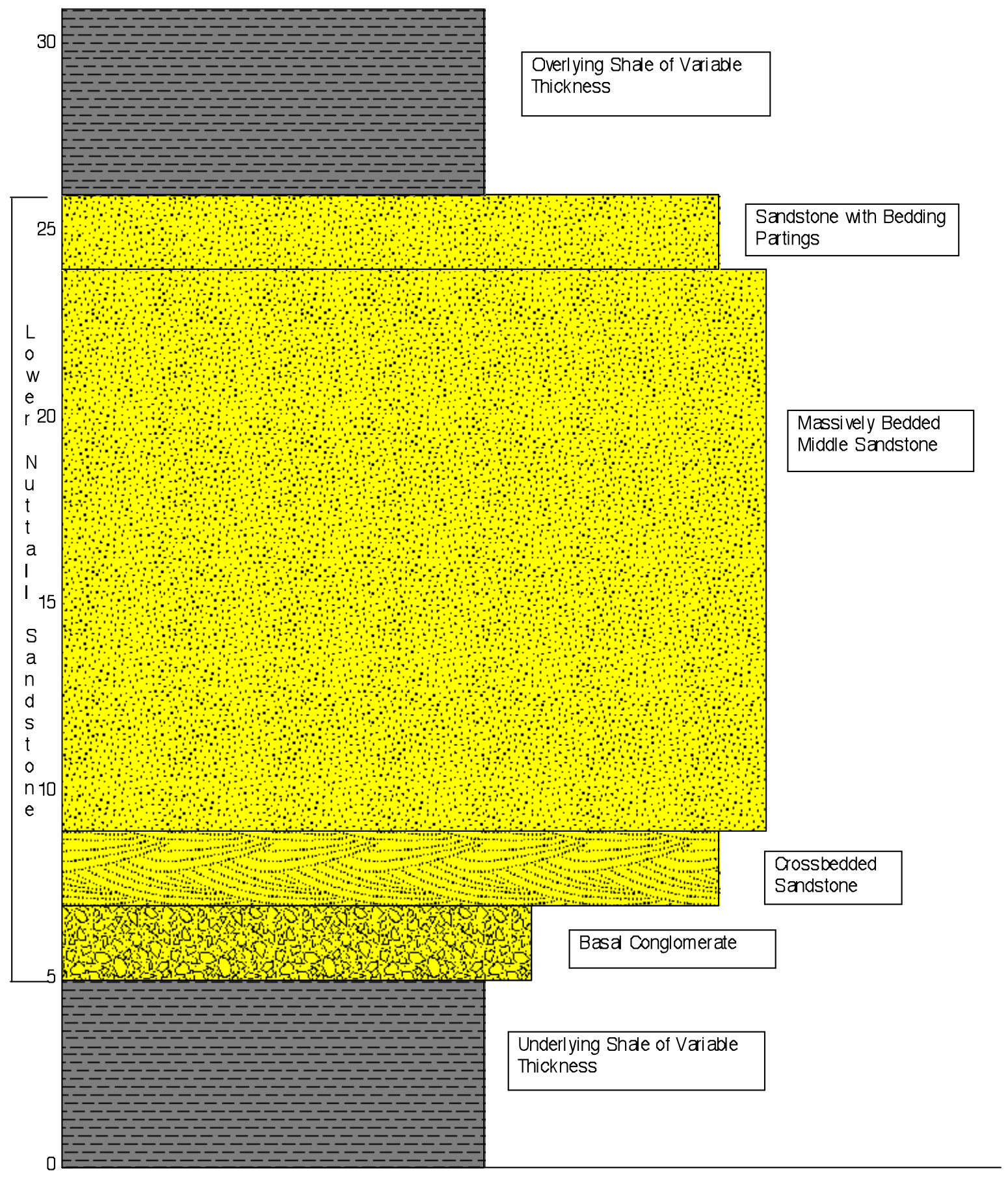

Figure 6: Stratigraphic column of lower Nuttall Sandstone interval and bounding units with thickness in meters and width indicating relative weathering profile of rock. 


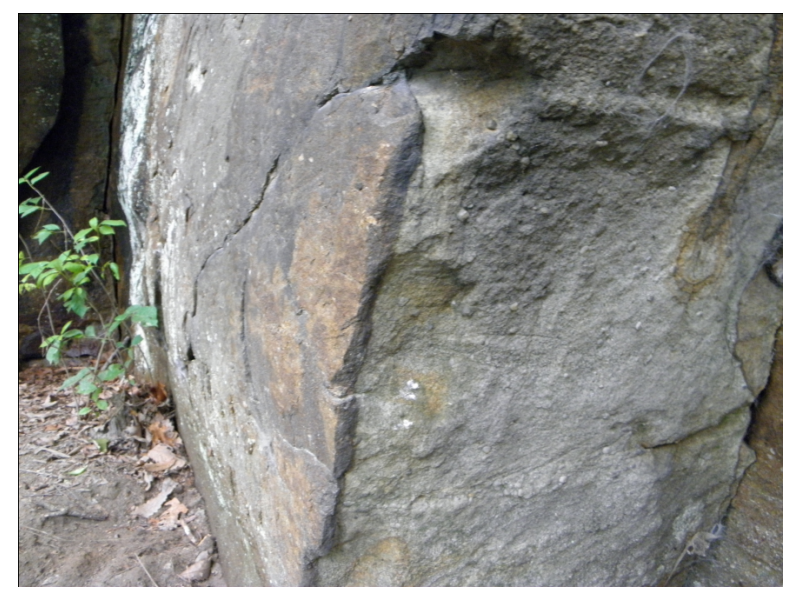

Figure 7: Cross section view of area with goethite in secondary pores coating sandstone block at Junkyard Wall.

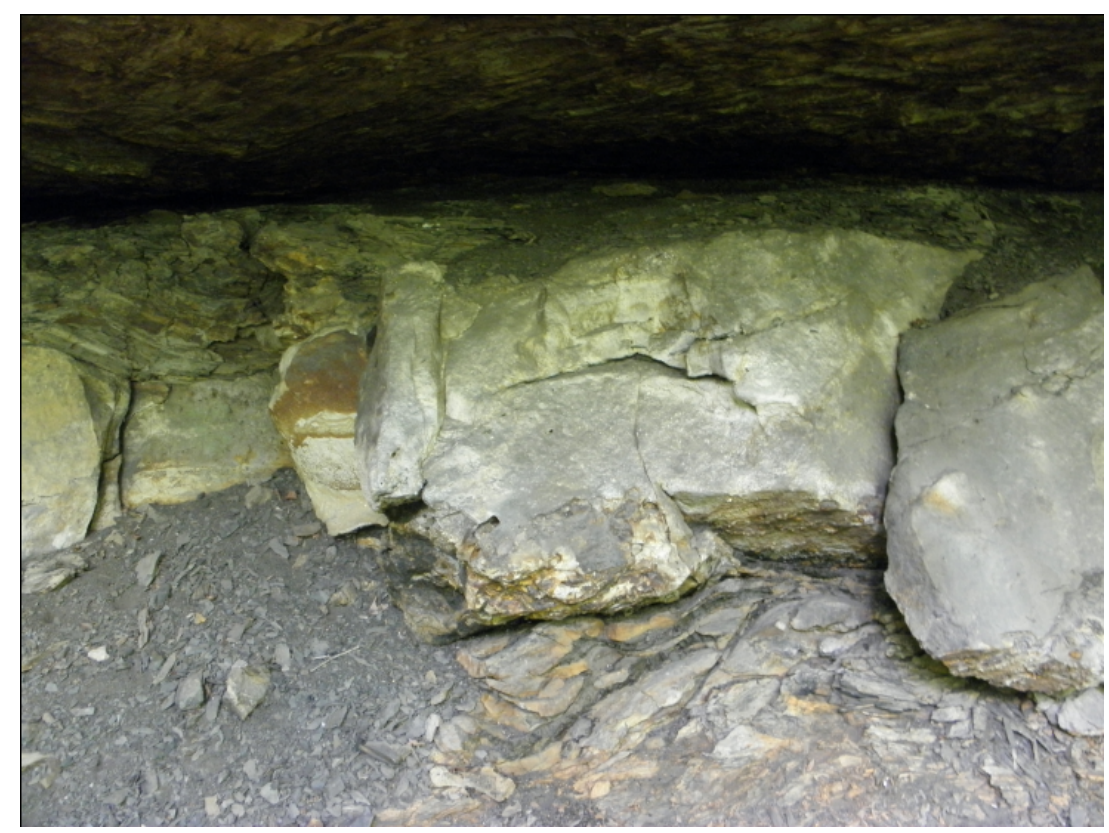

Figure 8: Basal conglomerate and shale at Endless Wall. 


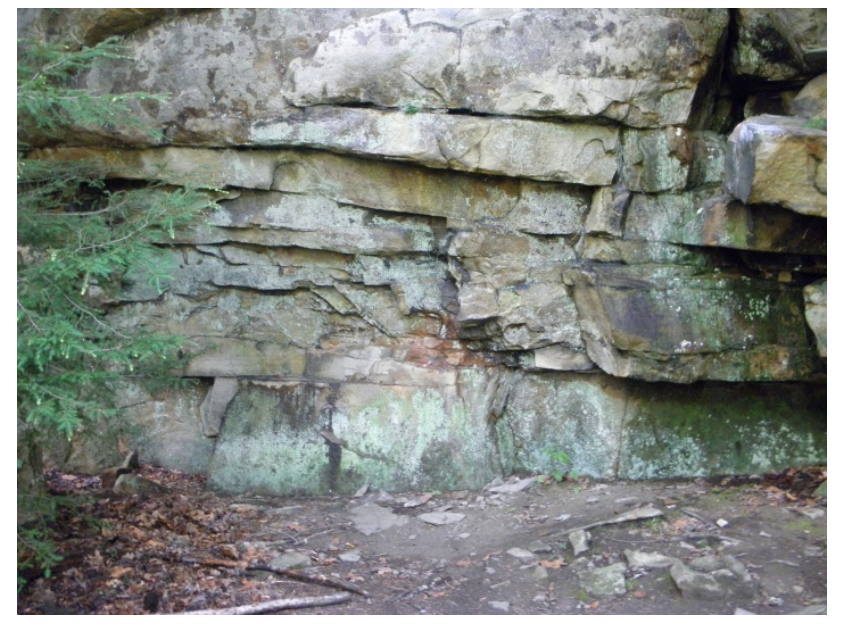

Figure 9: 2 m section of lower Nuttall Sandstone above basal conglomerate that is often crossbedded and contains obvious bedding partings. 


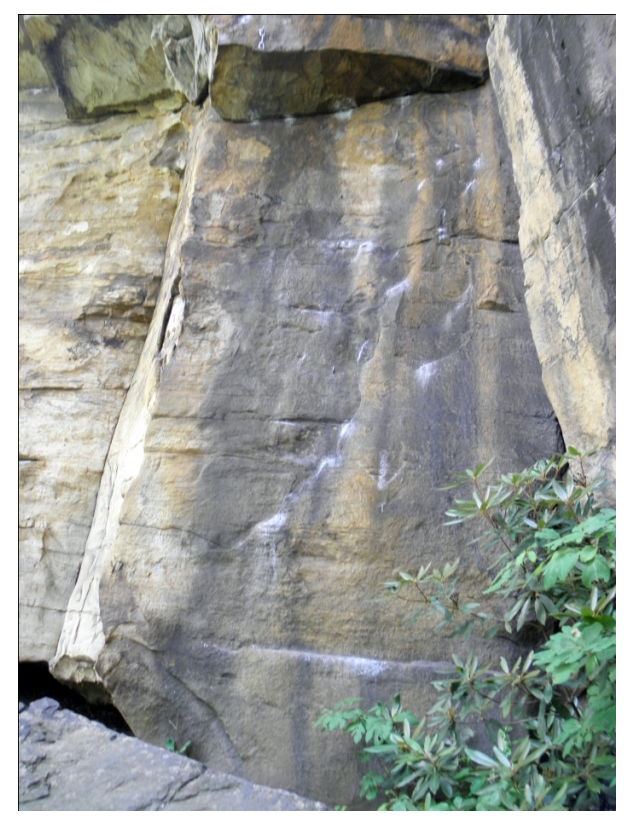

Figure 10: Climbed outcrop on Endless Wall that lacks pronounced bedding partings and has goethite in secondary pores on face.

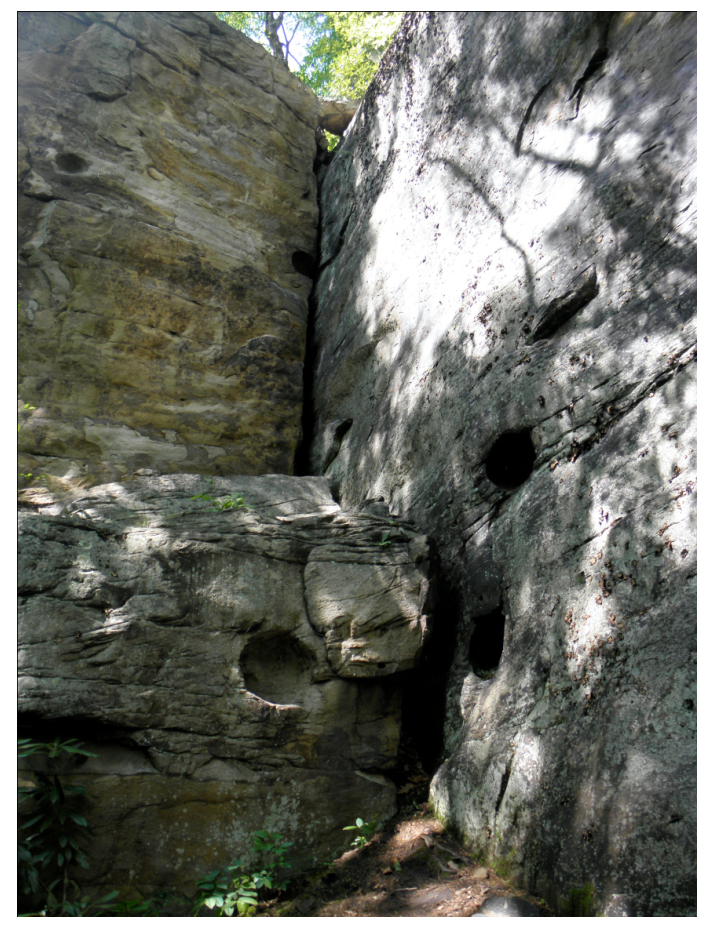

Figure 11: Weathering of conglomeratic lenses creating "Huecos" in Bridge Area. 


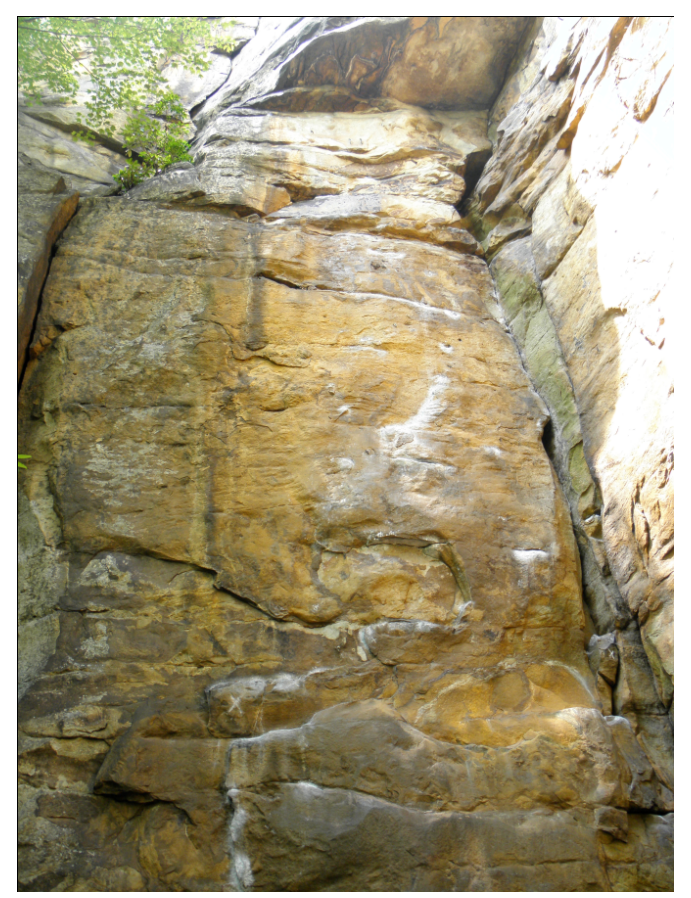

Figure 12: Massively bedded middle unit of lower Nuttall Sandstone with overhang in thinly bedded top unit at Endless Wall.

\section{Outcrop Investigations of Lower Nuttall and Other New River Formation Sandstones}

Outcrop investigation on the lower Nuttall Sandstone and other cliff forming sandstone in the New River Gorge area provided data for statistical analysis and comparison (Appendix 2). All measured cliff face orientations were found to be within $10^{\circ}$ of a known orientation (Table 3). Joints in the Nuttall Sandstone could be related to large scale tectonic processes, as their spacing and relative orientations are typical of joints of such an origin (Figure 13) (Davis and Reynolds 1996).

Schmidt hammer measurements performed at locations representative of the lower Nuttall Sandstone, but not necessarily on climbed routes (Figure 5 and Table 4), indicate the basal conglomerate is less mechanically strong (39.3) than the rest of the lower Nuttall 
Sandstone, and areas with goethite as a secondary cement along fractures (57.4 and 60.6) are on average mechanically stronger than sandstone lacking goethite (54.0-54.4). The Guyandot sandstone (60.0) is typically mechanically stronger than the massively bedded middle portion of the lower Nuttall Sandstone (54.4). The top, thinner bedded section of the lower Nuttall Sandstone (54.8) is similar in mechanical strength to the massively bedded middle section (54.4).

The lower Nuttall Sandstone was observed at two locations outside NERI: one along a railroad cut in the Gauley River National Recreation Area (GARI) and one at a railroad cut at Kanawha Falls, where the two members of the Nuttall Sandstone have coalesced to make one massive unit (Hennen 1919). Along the Gauley River, bedding is much thinner at 0.15 to $1.2 \mathrm{~m}$, and there is no basal conglomerate, although an unidentified coal occurs at the base. The thickness of the lower Nuttall Sandstone is only $15 \mathrm{~m}$. At Kanawha Falls, there are abundant erosional channels and, ranging from 0.15 to $0.3 \mathrm{~m}$ thick, bedding is thinner than in NERI with a middle unit of the massively bedded interval of only $9 \mathrm{~m}$. Thin sandy-shale intervals exist at the base and cross beds are abundant throughout, even in the massive middle unit, which is not the case in NERI. There is no apparent goethite cement at Kanawha Falls.

Observations of the upper Raleigh Sandstone were performed at two locations: one along a railroad grade in (GARI) and the other a natural cliff along the New River Gorge at Grandview State Park. Although the upper Raleigh Sandstone can be a cliff former, its 0.08 to $1 \mathrm{~m}$ thick bedding is much thinner than in the lower Nuttall Sandstone, with lenses of shale and obvious 0.01 to $0.05 \mathrm{~m}$ partings between bedding. Due to its bedding partings, the upper Raleigh Sandstone generally fails in smaller blocks parallel to bedding, contrary to larger blocks that form from the lower Nuttall Sandstone. Some localized areas of massive 10 to $12 \mathrm{~m}$ beds were observed in the upper Raleigh Sandstone at both locations, but they are underlain and overlain by 
thinly bedded rock that readily fails (Figure 14). The upper Raleigh Sandstone also has up to 1 $\mathrm{m}$ thick lenses of conglomerate that are laterally widespread, leading to an area in the middle of the unit that weathers preferentially, undercutting rock above and causing it to fail in a manner unsuitable for climbing.

The Guyandot sandstone was observed below Bridge Buttress along an abandoned road. The outcrop is likely man made due to road creation. The Guyandot sandstone has thinner beds of $0.15 \mathrm{~m}$ to $0.30 \mathrm{~m}$ with significant bedding partings, although not to the point of causing failure, that make for unchallenging climbing (Figure 15). Two bolted climbs were observed at the location, but are not frequently climbed except by novices visiting the location with climbing guides. The Guyandot sandstone exhibited a Schmidt hammer strength of 60.0, which is as mechanically strong or stronger than most measured values for the lower Nuttall Sandstone, with an average of 54.4 (Appendix 2).

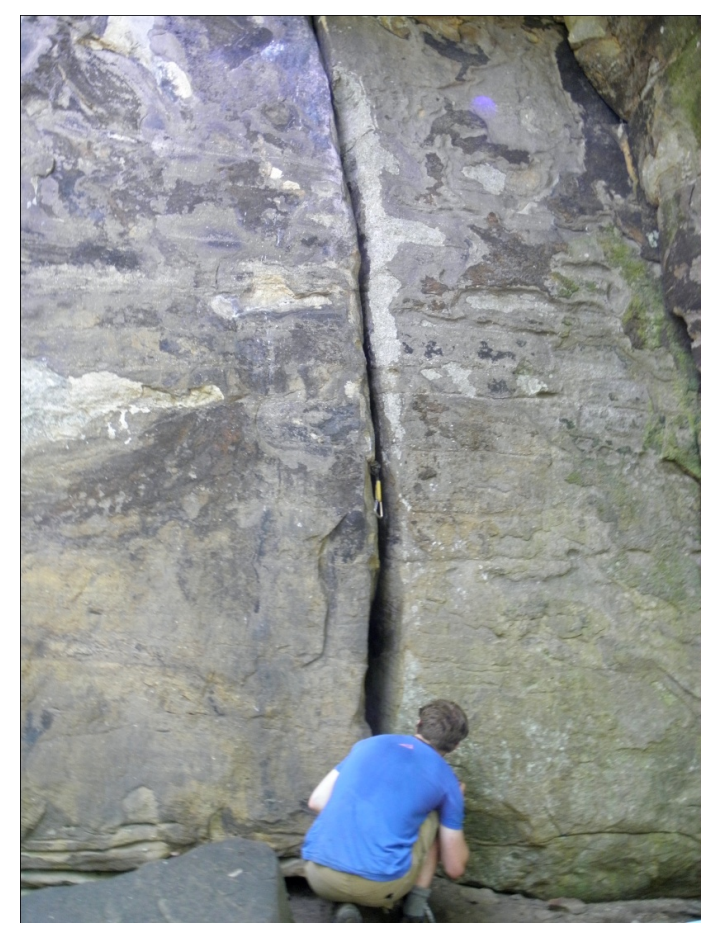

Figure 13: Pete Clark examining a tectonic joint that is popular for climbing at Fern

\section{Buttress.}




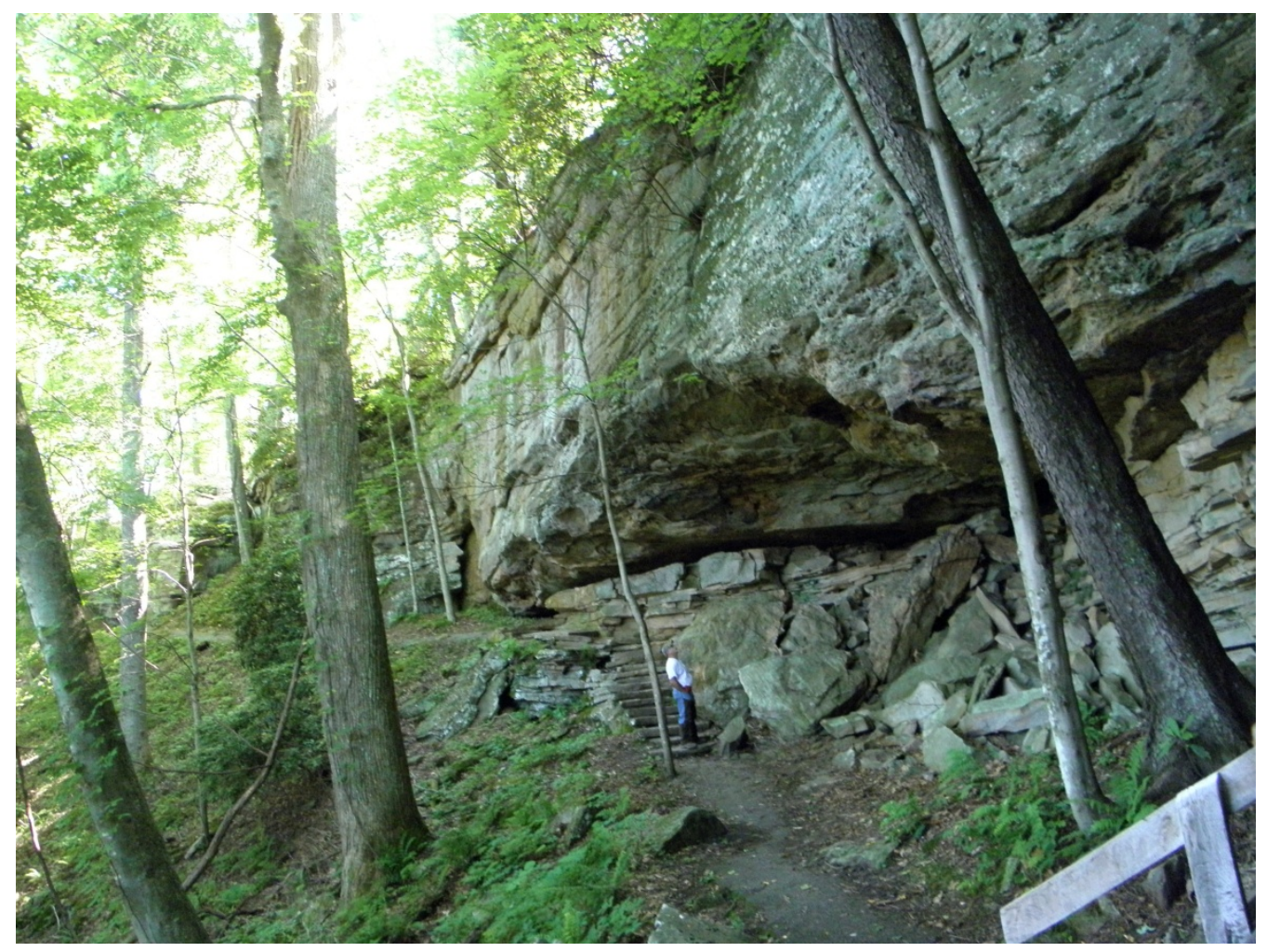

Figure 14: Variable bedding in the upper Raleigh Sandstone leading to small block failure.

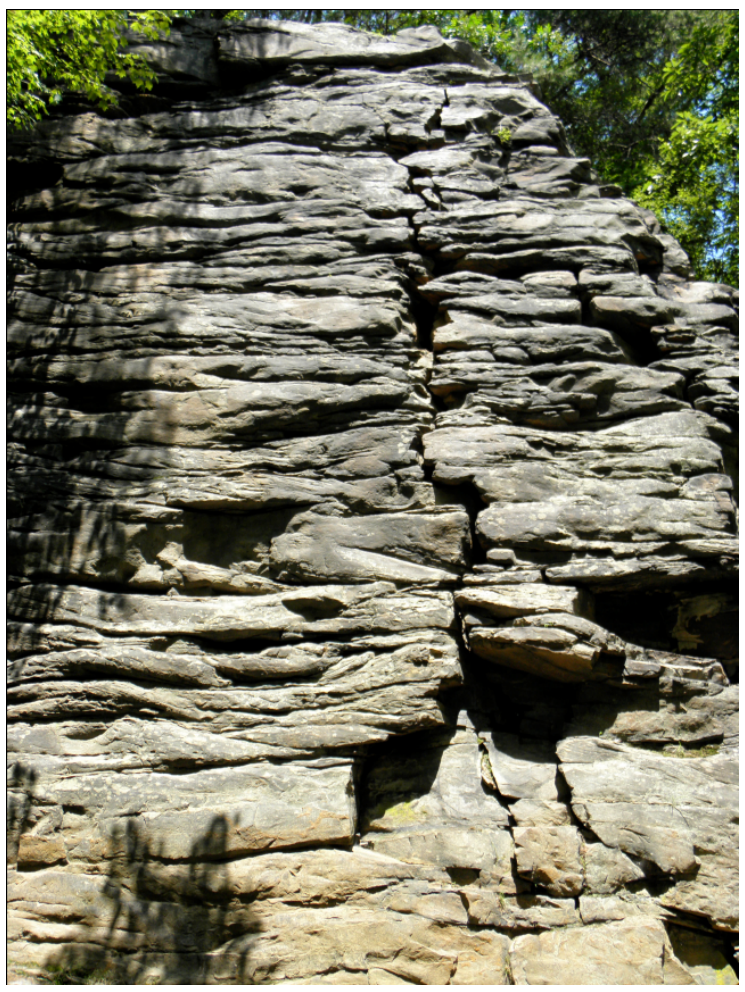

Figure 15: Thinly bedded Guyandot sandstone at climbed location below Bridge Buttress. 


\section{Mineralogy}

Thin section analyses of the lower Nuttall Sandstone indicates little to no primary porosity and goethite in the secondary pore space along fractures. No dust rims were apparent to differentiate cement from framework grains (Pettijohn et al. 1987). Thin Section 5 contained a stylolite horizontal to bedding. Point counts (Table 6) indicate the lower Nuttall Sandstone is composed primarily of monocrystalline quartz with a range of 65 to $90 \%$ in the lower portion and 87 to $90 \%$ in the massively bedded middle section in NERI. Polycrystalline quartz is also a significant component with a range of 3 to $22 \%$ in the lower section and 3 to $9 \%$ in the massively bedded middle section. Muscovite-containing rock fragments in various states of illite replacement range from 0 to $11 \%$ in the entire lower member and 0 to $3 \%$ in the massively bedded middle section. Accessory minerals include pyrite, tourmaline, and muscovite fragments. The massively bedded middle section shows 0 to $4 \%$ secondary porosity, which is filled with goethite in half of Thin Section 1 as it was sampled from a boundary with goethite as a secondary cement adjacent to a joint.

$\mathrm{XRD/XRF}$ results (Table 7) identify specific accessory minerals are ulvöspinel, arsenopyrite, and dravite. XRD/XRF results identify goethite, which based on thin section analysis, is present as cement in secondary pore space along joints. $\mathrm{XRD} / \mathrm{XRF}$ results indicate arsenopyrite as a minor component in the area with goethite in secondary pores along a joint.

The basal conglomerate of the lower Nuttall Sandstone has higher secondary porosity at $7.67 \%$ and a higher amount of rock fragments at $5.00 \%$. The top section of the lower Nuttall Sandstone has a higher amount of rock fragments at $10.67 \%$ and smaller grains. XRD analysis of a shale sample taken directly above the lower Nuttall Sandstone and of a shale sample taken directly below the lower Nuttall Sandstone detected no measurable arsenopyrite, goethite, or 
their polymorphs, meaning the shale is an unlikely source of the arsenopyrite in the lower Nuttall Sandstone. XRD on a sample of lower Nuttall Sandstone lacking goethite from the interior of a lower Nuttall Sandstone block indicated no arsenopyrite, goethite, or their polymorphs, which may indicate arsenopyrite and goethite are not sourced from the sandstone itself or that if they were present at some point in time, they have been removed.

One thin section each of upper Raleigh Sandstone and Guyandot sandstone were analyzed with point counts and are similar mineralogically to the lower Nuttall Sandstone, however they vary in the amount of rock fragments they contain. The upper Raleigh Sandstone is finer grained, not as well sorted, and has more rock fragments $(6 \%)$ than the lower Nuttall Sandstone. The Guyandot sandstone has a higher amount of rock fragments (11\%) than the lower Nuttall Sandstone and is finer grained.

Thin sections of the upper Nuttall Sandstone and lower Nuttall Sandstone from NAD 1983 UTM Zone 17N 4274550 m Northing, 521344 m Easting, or approximately 70 km north of the Fayetteville, West Virginia, and the New River Gorge near exit 57 on Interstate 79 (I-79) in West Virginia, were also analyzed. The upper Nuttall Sandstone has a high amount of rock fragments (23\%) and is coarser grained than the lower Nuttall Sandstone. At the northern I-79 location, the lower Nuttall Sandstone is similar to the bedrock unit in the gorge, although it contains a higher percentage $(8 \%)$ of rock fragments.

SEM/EDX/XRF performed on Thin Section 1, which is from the massively bedded middle portion of the lower Nuttall Sandstone, indicate silica and oxygen throughout the sample, as well as arsenic (Figures 16 to 19). The presence of other elements varies between the area with goethite in secondary pores and parts of the sample lacking goethite in secondary pores. Specifically, iron is present in the area with goethite in a secondary pore (Figure 19), whereas 
europium and neodymium were identified elsewhere in the sample (Figures 17 and 18) but not in the area with goethite in secondary pores.

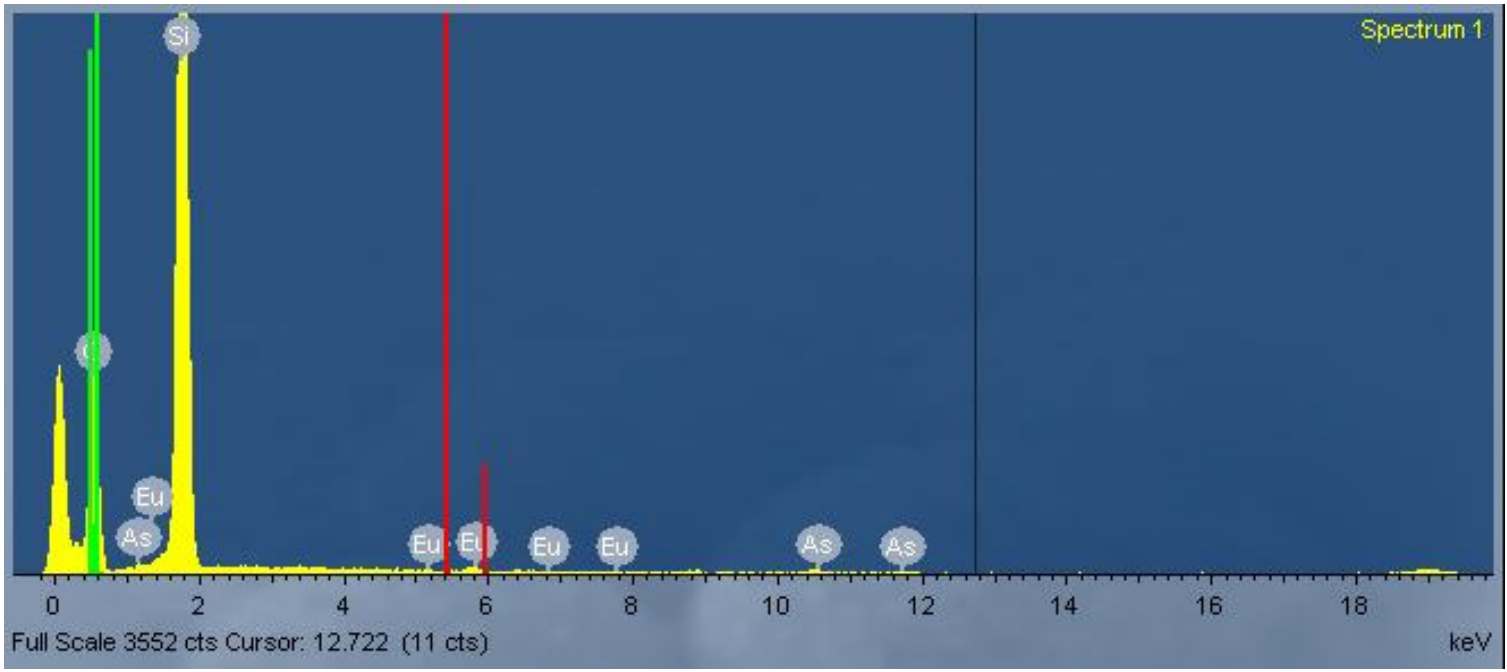

Figure 16: SEM/EDX spectrum of secondary pore lacking goethite of Thin Section 1 showing elements present as different colors with standard element abbreviations. 


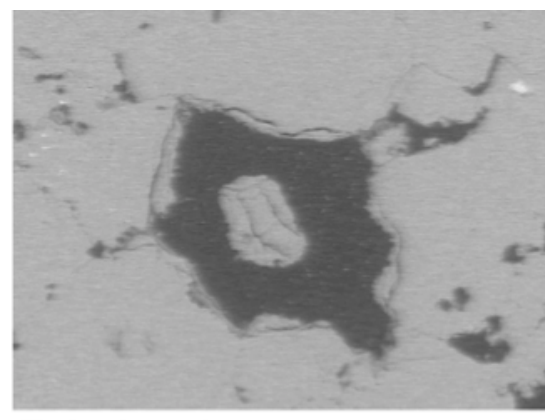

Electron Image 1

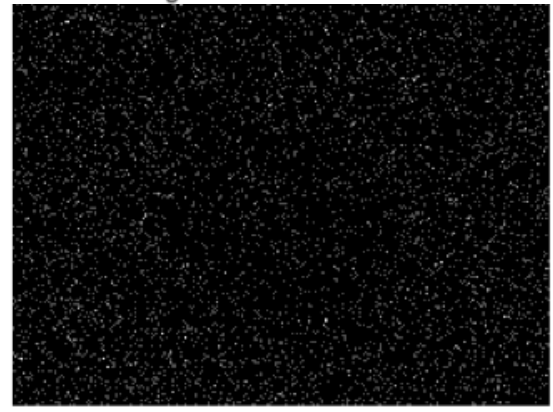

Nd La1

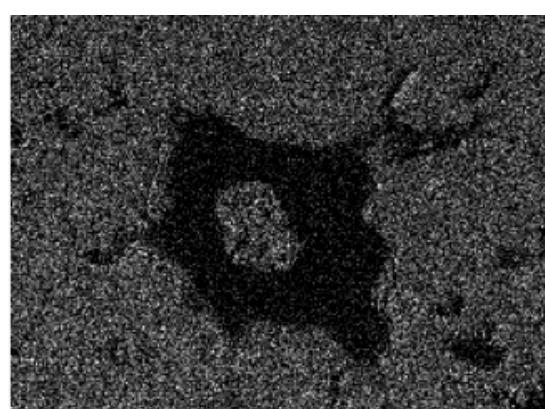

o Ka1

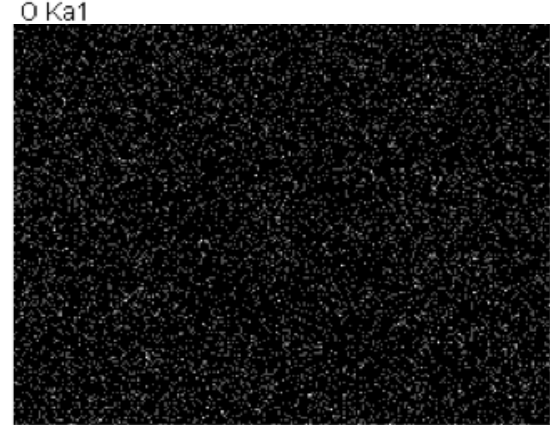

Eu La1

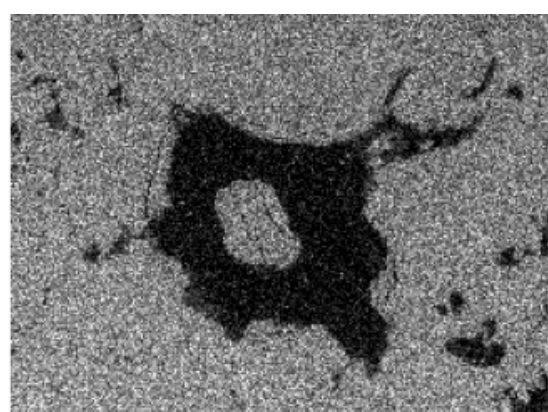

SiKa1

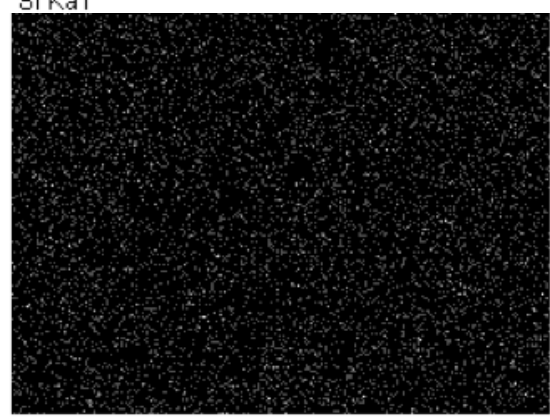

As Ka1

Figure 17: SEM/EDX element mapping of secondary pore without goethite of Thin Section

1 showing location of elements present in area mapped. Each element is mapped separately and labeled using standard abbreviations. 
A.
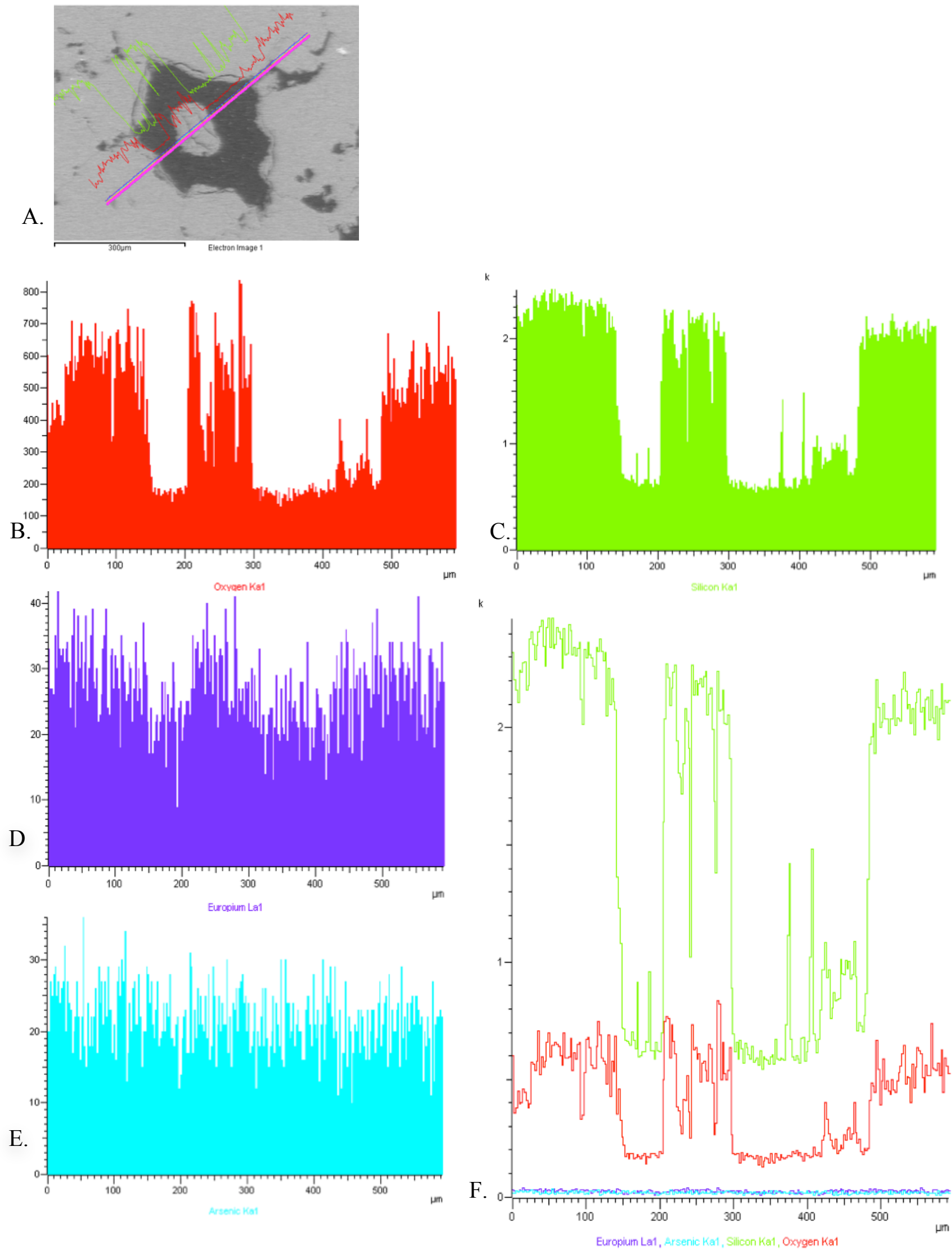
Figure 18: A. Photograph showing transect of Thin Section 1 in area without goethite analyzed for abundant elements present using SEM/EDX. B. Relative abundance of oxygen in transect. C. Relative abundance of silicon in transect. D. Graph summarizing relative abundance of elements in transect. E. Relative abundance of neodymium in transect. F. Relative abundance of arsenic in transect. 

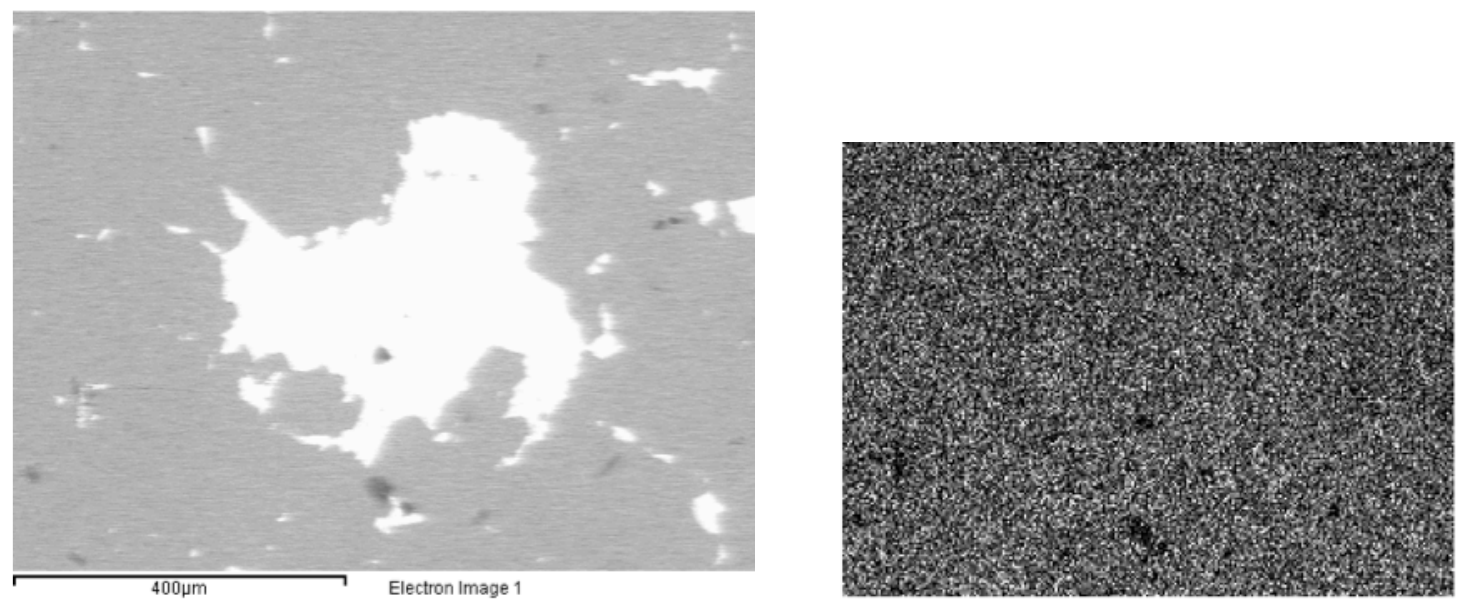

OKa1

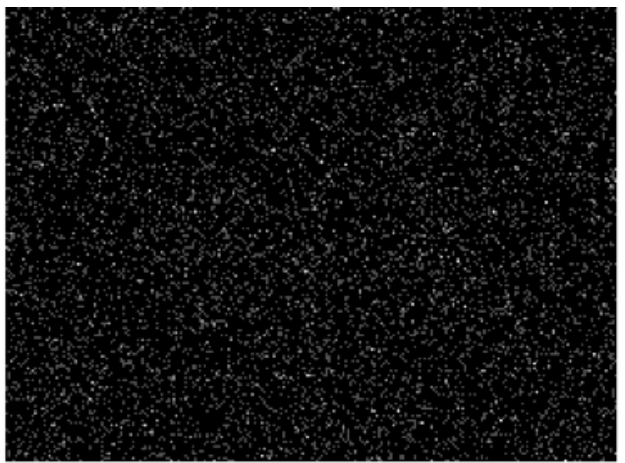

As Ka1

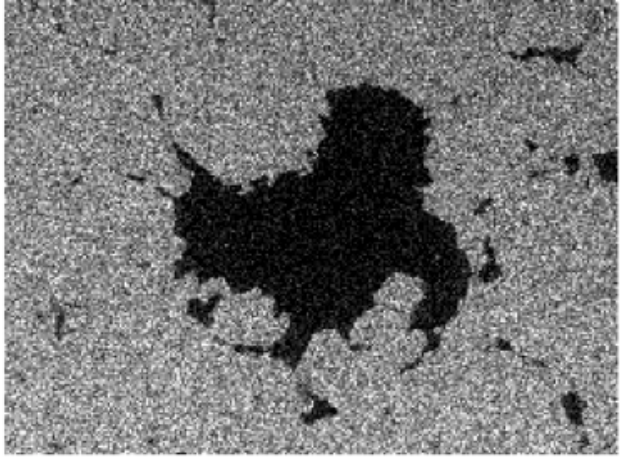

Si Ka1

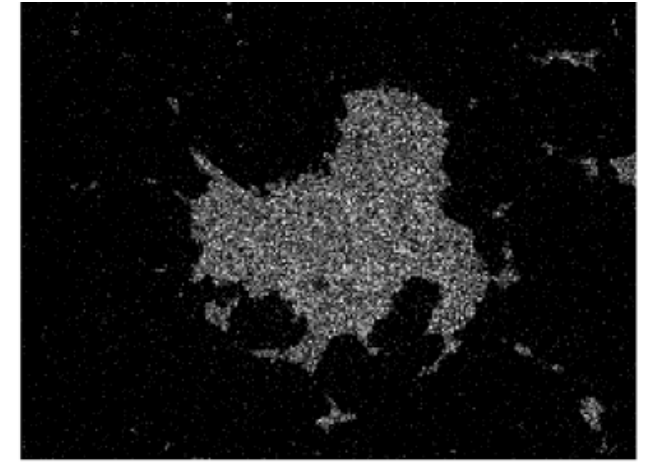

Fe Ka1

Figure 19: Images of element mapping using SEM/EDX on area of Thin Section 1 with goethite in secondary pore. The first image is the area mapped, and the rest of the image show specific element maps with elements abbreviated using standard abbreviation. 


\begin{tabular}{|c|c|c|c|c|c|c|c|}
\hline $\begin{array}{l}\text { Thin Section Location } \\
\text { Description }\end{array}$ & Number & $\begin{array}{l}\text { Monocrystalline } \\
\text { Quartz }\end{array}$ & $\begin{array}{l}\text { Polycrystalline } \\
\text { Quartz }\end{array}$ & $\begin{array}{l}\text { Secondary } \\
\text { Porosity }\end{array}$ & $\begin{array}{l}\text { Rock } \\
\text { Fragment } \\
\text { with } \\
\text { Micas } \\
\end{array}$ & $\begin{array}{l}\text { Accessory } \\
\text { Minerals }\end{array}$ & Notes \\
\hline \multicolumn{8}{|l|}{ Lower Nuttall Sandstone } \\
\hline Top Nuttall, Bridge Area & 2 & 76.33 & 11 & 2 & 10.67 & pyrite & $\begin{array}{l}\text { finer grained than middle, more } \\
\text { lithic }\end{array}$ \\
\hline $\begin{array}{l}\text { Middle Nuttall with } \\
\text { goethite, Bridge Area }\end{array}$ & 1 & 84.67 & 7.33 & 5.34 & 2.67 & tourmaline & has goethite \\
\hline $\begin{array}{l}\text { Middle Nuttall, Water } \\
\text { Seep, Beauty Mtn. }\end{array}$ & 5 & 90.33 & 4 & 1.33 & 4.33 & clay & Styolite, location was wet \\
\hline $\begin{array}{l}\text { Middle Nuttall, Beauty } \\
\text { Mtn. }\end{array}$ & 6 & 89.67 & 5 & 2.33 & 2.67 & pyrite & \\
\hline $\begin{array}{l}\text { Middle Nuttall, Domino } \\
\text { Point }\end{array}$ & 7 & 84.67 & 9.33 & 3 & 2.67 & $\begin{array}{l}\text { authigenic } \\
\text { quartz }\end{array}$ & largest grains \\
\hline $\begin{array}{l}\text { Middle Section, Sunshine } \\
\text { Buttress }\end{array}$ & 9 & 87.67 & 7 & 0.33 & 0.33 & pyrite & \\
\hline $\begin{array}{l}\text { Lower Nuttall from } \\
\text { WVGES, Exit 57, I-79 in } \\
\text { W.V. }\end{array}$ & 11 & 89.67 & 2.67 & 0 & 23 & 7.67 & \\
\hline Basal Conglomerate & 4 & 65.33 & 21.67 & 7.67 & 5 & biotite & \\
\hline \multicolumn{8}{|l|}{ Other Sandstones } \\
\hline $\begin{array}{l}\text { Upper Nuttall from } \\
\text { WVGES, Exit 57, I-79 in } \\
\text { W.V. }\end{array}$ & 10 & 62 & 14.67 & 0.33 & 22.67 & $\begin{array}{l}\text { degraded } \\
\text { feldspar }\end{array}$ & $\begin{array}{l}\text { coarse grained, not well sorted, more } \\
\text { lithic }\end{array}$ \\
\hline $\begin{array}{l}\text { Guyandot Sandstone } \\
\text { below Bridge }\end{array}$ & 3 & 88.67 & 4.33 & 1.34 & 5.67 & & fine grained \\
\hline $\begin{array}{l}\text { Upper Raleigh Sandstone, } \\
\text { below Bridge }\end{array}$ & 8 & 82 & 10.67 & 1 & 6.33 & & fine grained, not well sorted \\
\hline
\end{tabular}

Table 6: Thin section point-count results from New River Group sandstones in and around NERI. 


\begin{tabular}{|c|c|c|c|c|c|c|c|c|c|}
\hline \multicolumn{8}{|c|}{ [New_River_Gorge_Sandstone-ka.mdi] F Terra.157 axisX $=$} & \multicolumn{2}{|c|}{ PDF Overlay List } \\
\hline \multicolumn{10}{|c|}{ SCAN: $5.0 / 54.9 / 0.05 / 1(\mathrm{sec}), \mathrm{Co}, \mathrm{I}(\mathrm{p})=1389384,09 / 01 / 1010: 46 a$} \\
\hline \# & Phase ID & File ID & $1 \%$ & $2 \mathrm{~T}(0)$ & $d / d(0)$ & RIR & $\mathrm{Wt} \%$ & Tag & $\mathrm{XS}(\AA)$ \\
\hline 1 & Quartz - $\mathrm{SiO}_{2}$ & $98-000-0369$ & 100.0 & 0.000 & 1.0000 & 4.22 & 81.6 & Major & 334 \\
\hline 2 & Iron - Fe & $98-000-0259$ & 0.0 & 0.240 & 1.0000 & 11.91 & 0.0 & Absnt & $>1000$ \\
\hline 3 & Anorthite - $\mathrm{Ca}\left(\mathrm{Al}_{2} \mathrm{Si}_{2} \mathrm{O}_{8}\right)$ & $98-000-0093$ & 0.0 & -0.100 & 1.0000 & 0.56 & 0.0 & Absnt & $>1000$ \\
\hline 4 & Chalcopyrite - CuFeS 2 & $98-000-0156$ & 0.0 & -0.180 & 1.0000 & 7.90 & 0.0 & Absnt & $>1000$ \\
\hline 5 & Goethite - $\mathrm{FeO}(\mathrm{OH})$ & $98-000-0229$ & 8.2 & -0.160 & 1.0000 & 2.63 & 3.1 & Minor & $>1000$ \\
\hline 6 & Orthoclase - $\mathrm{KAISi}_{3} \mathrm{O}_{8}$ & $98-000-0338$ & 0.0 & -0.400 & 1.0000 & 0.68 & 0.0 & Absnt & 334 \\
\hline 7 & Ulvospinel - $\mathrm{Fe}_{2}\left(\mathrm{TiO}_{4}\right)$ & $98-000-0445$ & 2.2 & -0.080 & 1.0000 & 4.73 & 1.2 & Trace & 496 \\
\hline 8 & Kaolinite - $\mathrm{Al}_{4}(\mathrm{OH})_{8}\left(\mathrm{Si}_{4} \mathrm{O}_{10}\right)$ & $98-000-0261$ & 0.0 & 0.140 & 1.0000 & 0.86 & 0.0 & Absnt & $>1000$ \\
\hline 9 & Albite - $\mathrm{Na}\left(\mathrm{AlSi}_{3} \mathrm{O}_{8}\right)$ & $98-000-0041$ & 0.0 & 0.200 & 1.0000 & 0.65 & 0.0 & Absnt & $>1000$ \\
\hline 10 & Hastingsite $-\mathrm{NaCa}_{2}\left(\mathrm{Fe}^{+2}, \mathrm{Mg}\right)_{4} \mathrm{Fe}^{+3}\left(\mathrm{Si}_{6} \mathrm{Al}_{2}\right)$ & $.99-000-1480$ & 0.0 & -0.240 & 1.0000 & $?$ & 0.0 & Absnt & $>1000$ \\
\hline 11 & Manganite - $\mathrm{MnO}(\mathrm{OH})$ & $98-000-0296$ & 0.0 & 0.200 & 1.0000 & 4.27 & 0.0 & Absnt & $>1000$ \\
\hline 12 & Magnesium - $(\mathrm{MgCa}) \mathrm{CO}_{3}$ & $98-000-0293$ & 0.0 & 0.200 & 1.0000 & 2.86 & 0.0 & Absnt & $>1000$ \\
\hline 13 & Muscovite - $\mathrm{K}\left(\mathrm{Al}_{1.91} \mathrm{Fe}_{.09}\right)\left(\mathrm{Si}_{3} \mathrm{Al}\right) \mathrm{O}_{10}(\mathrm{OH})_{2}$ & $98-000-0322$ & 0.0 & -0.040 & 1.0000 & 0.63 & 0.0 & Absnt & 496 \\
\hline 14 & Arsenopyrite - AsFeS & $98-000-0101$ & 4.1 & -0.200 & 1.0000 & 2.09 & 5.3 & Minor & 477 \\
\hline 15 & Muscovite $\left.-\mathrm{KAl}_{2}\left[\mathrm{Si}_{3} \mathrm{~B}\right] \mathrm{O}_{10}\right](\mathrm{OH})_{2}$ & $98-000-0320$ & 1.8 & -0.080 & 1.0000 & 0.86 & 4.4 & Minor & 658 \\
\hline 16 & Chlorite - MgFeSiAlOOH & $98-000-0159$ & 0.0 & -0.060 & 1.0000 & 1.50 & 0.0 & Absnt & $>1000$ \\
\hline 17 & Staurolite - $\mathrm{Zn}_{0.04} \mathrm{Fe}_{3.4} \mathrm{Si}_{7.8} \mathrm{Al}_{18.72} \mathrm{Mgg}_{0.8} \mathrm{O}_{48}$ & $98-000-0410$ & 0.0 & -0.120 & 1.0000 & 0.44 & 0.0 & Absnt & $>1000$ \\
\hline 18 & Dravite - $\mathrm{NaMg}_{3} \mathrm{Al}_{6}\left(\mathrm{BO}_{3}\right)_{3}\left(\mathrm{Si}_{6} \mathrm{O}_{18}\right)(\mathrm{OH})_{4}$ & $98-000-0201$ & 3.5 & -0.140 & 1.0000 & 0.89 & 3.9 & Minor & $>1000$ \\
\hline 19 & Magnetite - $\mathrm{Fe}_{3} \mathrm{O}_{4}$ & $98-000-0294$ & 0.0 & 0.000 & 1.0000 & 5.22 & 0.0 & Absnt & $>1000$ \\
\hline 20 & Microcline - $\mathrm{K}\left(\mathrm{AlSi}_{3} \mathrm{O}_{8}\right)$ & $98-000-0305$ & 0.0 & 0.200 & 1.0000 & 0.62 & 0.0 & Absnt & $>1000$ \\
\hline 21 & Magnesite - $\mathrm{MgCO}_{3}$ & $98-000-0292$ & 0.0 & 0.060 & 1.0000 & 1.91 & 0.0 & Absnt & $>1000$ \\
\hline 22 & Rutile - $\mathrm{TiO}_{2}$ & $98-000-0375$ & 0.0 & -0.020 & 1.0000 & 3.40 & 0.0 & Absnt & $>1000$ \\
\hline 23 & Perovskite - $\mathrm{Ca}\left(\mathrm{TiO}_{3}\right)$ & $98-000-0350$ & 0.0 & 0.100 & 1.0000 & 2.64 & 0.0 & Absnt & $>1000$ \\
\hline 24 & Muscovite - $\mathrm{Kal}_{2}\left[\mathrm{Si}_{3} \mathrm{All}\right] \mathrm{O}_{10}(\mathrm{OH})_{2}$ & $98-000-0321$ & 0.0 & -0.040 & 1.0000 & 0.40 & 0.0 & Absnt & $>1000$ \\
\hline 25 & Fayalite $-\mathrm{Fe}_{2}\left(\mathrm{SiO}_{4}\right)$ & $98-000-0212$ & 0.0 & 0.020 & 1.0000 & 1.53 & 0.0 & Absnt & $>1000$ \\
\hline 26 & Marcasite - $\mathrm{FeS}_{2}$ & $98-000-0298$ & 0.0 & 0.060 & 1.0000 & 2.50 & 0.0 & Absnt & $>1000$ \\
\hline 27 & Ilmenite - $\mathrm{FeTiO}_{3}$ & $98-000-0255$ & 1.3 & -0.120 & 1.0000 & 2.95 & 0.4 & Trace & $>1000$ \\
\hline 28 & Kutnohorite - $\mathrm{CaMn}\left(\mathrm{CO}_{3}\right)_{2}$ & $98-000-0269$ & 0.0 & -0.180 & 1.0000 & 3.02 & 0.0 & Absnt & $>1000$ \\
\hline 29 & Brookite $-\mathrm{TiO}_{2}$ & $98-000-0128$ & 0.0 & 0.200 & 1.0000 & 1.53 & 0.0 & Absnt & $>1000$ \\
\hline 30 & Hematite - $\mathrm{Fe}_{2} \mathrm{O}_{3}$ & $98-000-0240$ & 0.0 & 0.040 & 1.0000 & 3.18 & 0.0 & Absnt & $>1000$ \\
\hline 31 & Aegirine - $\mathrm{NaFeSi}_{2} \mathrm{O}_{6}$ & $98-000-0015$ & 0.0 & 0.200 & 1.0000 & 1.54 & 0.0 & Absnt & $>1000$ \\
\hline 32 & Elbaite - $\mathrm{Na}(\mathrm{Al}, \mathrm{Li})_{3} \mathrm{Al}_{6}\left(\mathrm{BO}_{3}\right)_{3} \mathrm{Si}_{6} \mathrm{O}_{18}(\mathrm{OH})_{4}$ & $98-000-0204$ & 0.0 & 0.060 & 1.0000 & 0.70 & 0.0 & Absnt & $>1000$ \\
\hline 33 & Almandine - $\mathrm{Fe}_{3} \mathrm{Al}_{2}\left(\mathrm{SiO}_{4}\right)_{3}$ & $98-000-0053$ & 0.0 & -0.020 & 1.0000 & 2.86 & 0.0 & Absnt & $>1000$ \\
\hline 34 & Augite - $\mathrm{FeCa}_{4} \mathrm{Si}_{8} \mathrm{Mg}_{2.86} \mathrm{O}_{24}$ & $98-000-0102$ & 0.0 & 0.000 & 1.0000 & 1.17 & 0.0 & Absnt & $>1000$ \\
\hline 35 & Pyrrhotite $-\mathrm{Fe}_{7} \mathrm{~S}_{8}$ & $98-000-0368$ & 0.0 & 0.200 & 1.0000 & 3.89 & 0.0 & Absnt & $>1000$ \\
\hline 36 & Pyrite - FeS 2 & $98-000-0363$ & 0.0 & 0.140 & 1.0000 & 3.07 & 0.0 & Absnt & $>1000$ \\
\hline 37 & Siderite - $\mathrm{FeCO}_{3}$ & $98-000-0391$ & 0.0 & 0.060 & 1.0000 & 3.32 & 0.0 & Absnt & $>1000$ \\
\hline 38 & Rhodochrosite - $\mathrm{MnCO}_{3}$ & $98-000-0372$ & 0.0 & -0.080 & 1.0000 & 3.30 & 0.0 & Absnt & $>1000$ \\
\hline 39 & Zircon - $\mathrm{ZrSiO}_{4}$ & $98-000-0490$ & 0.0 & -0.200 & 1.0000 & 5.01 & 0.0 & Absnt & $>1000$ \\
\hline 40 & Biotite - $\mathrm{K}(\mathrm{Mg}, \mathrm{Fe})_{3} \mathrm{Al}\left[\mathrm{Si}_{3} \mathrm{O}_{10}\right] \mathrm{F}_{2}$ & $98-000-0117$ & 0.0 & 0.120 & 1.0000 & 1.26 & 0.0 & Absnt & $>1000$ \\
\hline 41 & Swinefordite - $\mathrm{Ca}_{0.2}(\mathrm{Li}, \mathrm{Al}, \mathrm{Mg}, \mathrm{Fe})_{3}(\mathrm{Si}, \mathrm{Al})_{4} \mathrm{O}$ & $.99-000-3597$ & 0.0 & 0.200 & 1.0000 & $?$ & 0.0 & Absnt & $>1000$ \\
\hline 42 & Ferrihydrite $-\left(\mathrm{Fe}^{+3}\right)_{4-5}(\mathrm{OH}, \mathrm{O})_{12}$ & $99-000-1132$ & 0.0 & 0.000 & 1.0000 & $?$ & 0.0 & Absnt & $>1000$ \\
\hline 43 & Volkonskoite - $\mathrm{Ca}_{0.3}(\mathrm{Cr}, \mathrm{Mg})_{2}(\mathrm{Si}, \mathrm{Al})_{4} \mathrm{O}_{10}(\mathrm{O}$. & $99-000-4220$ & 0.0 & -0.040 & 1.0000 & $?$ & 0.0 & Absnt & $>1000$ \\
\hline 44 & Beidellite - $(\mathrm{Na}, \mathrm{Ca})_{0.3} \mathrm{Al}_{2}(\mathrm{Si}, \mathrm{Al})_{4} \mathrm{O}_{10}(\mathrm{OH})_{2} \mathrm{~N}$ & $.99-000-0306$ & 0.0 & 0.020 & 1.0000 & $?$ & 0.0 & Absnt & $>1000$ \\
\hline 45 & Illite- $1 \mathrm{M}-\left(\mathrm{K}, \mathrm{H}_{3} \mathrm{O}\right) \mathrm{Al}_{2}\left(\mathrm{Si}_{3} \mathrm{Al}\right) \mathrm{O}_{10}\left(\mathrm{H}_{2} \mathrm{O}, \mathrm{OH}\right)_{2}$ & $99-000-1661$ & 0.0 & -0.200 & 1.0000 & $?$ & 0.0 & Absnt & $>1000$ \\
\hline 46 & Hectorite - $\mathrm{Na}_{0.3}(\mathrm{Mg}, \mathrm{Li})_{3} \mathrm{Si}_{4} \mathrm{O}_{10}(\mathrm{~F}, \mathrm{OH})_{2} \cdot{ }_{\mathrm{N}} \mathrm{H}$. & $.99-000-1497$ & 0.0 & 0.200 & 1.0000 & $?$ & 0.0 & Absnt & $>1000$ \\
\hline 47 & Akhtenskite - $\mathrm{MnO}_{2}$ & $99-000-0036$ & 0.0 & -0.020 & 1.0000 & $?$ & 0.0 & Absnt & $>1000$ \\
\hline 48 & Saponite - $(\mathrm{Ca}, \mathrm{Na})_{0.3}(\mathrm{Mg}, \mathrm{Fe})_{3}(\mathrm{Si}, \mathrm{Al})_{4} \mathrm{O}_{10}($. & $99-000-3270$ & 0.0 & 0.060 & 1.0000 & $?$ & 0.0 & Absnt & $>1000$ \\
\hline 49 & Glauconite - $(\mathrm{K}, \mathrm{Na})\left(\mathrm{Fe}^{+3}, \mathrm{Al}, \mathrm{Mg}\right)_{2}(\mathrm{Si}, \mathrm{Al})_{4} \mathrm{O}_{1}$ & $.99-000-1363$ & 0.0 & -0.140 & 1.0000 & $?$ & 0.0 & Absnt & $>1000$ \\
\hline 50 & Nontronite $-\mathrm{Na}_{0.3}\left(\mathrm{Fe}^{+3}\right)_{2}(\mathrm{Si}, \mathrm{Al})_{4} \mathrm{O}_{10}(\mathrm{OH})_{2}$. & $99-000-2679$ & 0.0 & 0.020 & 1.0000 & $?$ & 0.0 & Absnt & $>1000$ \\
\hline 51 & Illite - $\left(\mathrm{K}, \mathrm{H}_{3} \mathrm{O}\right) \mathrm{Al}_{2}\left(\mathrm{Si}_{3} \mathrm{Al}\right) \mathrm{O}_{10}\left(\mathrm{H}_{2} \mathrm{O}, \mathrm{OH}\right)_{2}$ & $99-000-1660$ & 0.0 & -0.040 & 1.0000 & $?$ & 0.0 & Absnt & $>1000$ \\
\hline 52 & Aliettite $-\mathrm{Ca}_{0.2} \mathrm{Mg}_{6}(\mathrm{Si}, \mathrm{Al})_{8} \mathrm{O}_{20}(\mathrm{OH})_{4} \cdot 4 \mathrm{H}_{2} \mathrm{O}$ & $99-000-0052$ & 0.0 & 0.200 & 1.0000 & $?$ & 0.0 & Absnt & $>1000$ \\
\hline 53 & Sauconite $-\mathrm{Na}_{0.3} \mathrm{Zn}_{3}(\mathrm{Si}, \mathrm{Al})_{4} \mathrm{O}_{10}(\mathrm{OH})_{2} \cdot 4 \mathrm{H}_{2}$ & $99-000-3284$ & 0.0 & -0.040 & 1.0000 & $?$ & 0.0 & Absnt & $>1000$ \\
\hline 54 & Stevensite - $(\mathrm{Ca}, \mathrm{Na})_{x} \mathrm{Mg}_{3-x} \mathrm{Si}_{4} \mathrm{O}_{10}(\mathrm{OH})_{2}$ & $99-000-3507$ & 0.0 & -0.100 & 1.0000 & $?$ & 0.0 & Absnt & $>1000$ \\
\hline
\end{tabular}

Table 7: XRD/XRF results with \% weight of minerals in Thin Section 


\section{Statistical Analysis of Observed Data}

Spearman's rank coefficient values and corresponding p-values (Table 8) indicate several significant patterns when a p-value of 0.05 or less was considered to be statistically significant. Specifically, level of surface feature in bolted and non-bolted climbs was correlated with star number at a p-value of 0.0169 . Grade of climb was correlated with level of surface feature in bolted and nonbolted climbs at a p-value of 0.0249. Other variables appear loosely correlated, however, not at a significant level. These loose correlations could be indications of real patterns, and in the future, might be candidates for further work. For example, level of surface features correlates with strength from Schmidt hammer readings at bolted and nonbolted climbs at a p-value of 0.0881 . 


\begin{tabular}{|c|c|c|c|c|c|}
\hline VARIABLES & $r s=$ & $\mathbf{p}=$ & VARIABLES & $r s=$ & $p=$ \\
\hline Surface Features with Stars & & & Use with Mechanical Strength & & \\
\hline Anchor Bolts & 0.330 & 0.180 & Anchor Bolts & & $>0.3$ \\
\hline Bolts & & $>0.3$ & Bolts & 0.231 & 0.236 \\
\hline No Bolts & & $>0.3$ & No Bolts & & $>0.3$ \\
\hline All & 0.150 & 0.227 & All & & $>0.3$ \\
\hline Bolts and Anchors & & $>0.3$ & Bolts and Anchors & & $>0.3$ \\
\hline No Bolts and Anchors & & $>0.3$ & No Bolts and Anchors & & $>0.3$ \\
\hline Bolts and No Bolts & 0.340 & 0.0169 & Bolts and No Bolts & & $>0.3$ \\
\hline $\begin{array}{l}\text { Grade with Surface } \\
\text { Features }\end{array}$ & & & $\begin{array}{l}\text { Surface Features with } \\
\text { Mechanical Strength }\end{array}$ & & \\
\hline Anchor Bolts & & $>0.3$ & Anchor Bolts & 0.336 & 0.239 \\
\hline Bolts & & $>0.3$ & Bolts & 0.235 & 0.228 \\
\hline No Bolts & & $>0.3$ & No Bolts & & $>0.3$ \\
\hline All & 0.208 & 0.0918 & All & & $>0.3$ \\
\hline Bolts and Anchors & & $>0.3$ & Bolts and Anchors & & $>0.3$ \\
\hline No Bolts and Anchors & & $>0.3$ & No Bolts and Anchors & & $>0.3$ \\
\hline Bolts and No Bolts & 0.320 & 0.0249 & Bolts and No Bolts & 0.266 & 0.0881 \\
\hline $\begin{array}{l}\text { Surface Features and } \\
\text { Orientation }\end{array}$ & & & $\begin{array}{l}\text { Stars with Mechanical } \\
\text { Strength }\end{array}$ & & \\
\hline Anchor Bolts & & $>0.3$ & Anchor Bolts & & $>0.3$ \\
\hline Bolts & & $>0.3$ & Bolts & & $>0.3$ \\
\hline No Bolts & 0.337 & 0.158 & No Bolts & 0.356 & 0.211 \\
\hline All & & $>0.3$ & All & & $>.3$ \\
\hline Bolts and Anchors & & $>0.3$ & Bolts and Anchors & & $>0.3$ \\
\hline No Bolts and Anchors & & $>0.3$ & No Bolts and Anchors & & $>0.3$ \\
\hline Bolts and No Bolts & & $>0.3$ & Bolts and No Bolts & & $>0.3$ \\
\hline Stars and Orientation & & & $\begin{array}{l}\text { Grade with Mechanical } \\
\text { Strength }\end{array}$ & & \\
\hline Anchor Bolts & & $>0.3$ & Anchor Bolts & & $>0.3$ \\
\hline Bolts & & $>0.3$ & Bolts & & $>0.3$ \\
\hline No Bolts & 0.387 & 0.102 & No Bolts & 0.320 & 0.265 \\
\hline All & & $>0.3$ & All & & $>0.3$ \\
\hline Bolts and Anchors & & $>0.3$ & Bolts and Anchors & & $>0.3$ \\
\hline No Bolts and Anchors & 0.201 & 0.239 & No Bolts and Anchors & & $>0.3$ \\
\hline Bolts and No Bolts & & $>0.3$ & Bolts and No Bolts & & $>0.3$ \\
\hline Grade and Orientation & & & $\begin{array}{l}\text { Mechanical Strength and } \\
\text { Orientation }\end{array}$ & & \\
\hline Anchor Bolts & & $>0.3$ & Anchor Bolts & & $>0.3$ \\
\hline Bolts & & $>0.3$ & Bolts & & $>0.3$ \\
\hline No Bolts & 0.397 & 0.0921 & No Bolts & & $>0.3$ \\
\hline All & & $>0.3$ & All & & $>0.3$ \\
\hline Bolts and Anchors & & $>0.3$ & Bolts and Anchors & 0.212 & 0.183 \\
\hline No Bolts and Anchors & & $>0.3$ & No Bolts and Anchors & & $>0.3$ \\
\hline Bolts and No Bolts & & $>0.3$ & Bolts and No Bolts & & $>0.3$ \\
\hline
\end{tabular}




\begin{tabular}{|l|l|l|}
\hline VARIABLES & $\mathbf{r s}=$ & $\mathbf{p}=$ \\
\hline $\begin{array}{l}\text { Use and } \\
\text { Orientation }\end{array}$ & & \\
\hline Anchor Bolts & & $>0.3$ \\
\hline Bolts & & $>0.3$ \\
\hline No Bolts & & $>0.3$ \\
\hline All & & $>0.3$ \\
\hline Bolts and Anchors & & $>0.3$ \\
\hline $\begin{array}{l}\text { No Bolts and } \\
\text { Anchors }\end{array}$ & 0.20419 & 0.232 \\
\hline Bolts and No Bolts & & $>0.3$ \\
\hline
\end{tabular}

Table 8: Statistical results of variable correlation with p-values $>0.3$ reported as such and $p$ values $<0.03$ reported as actual values. Significant values or $p$ values $<\mathbf{0 . 0 5}$ bolded. 


\section{DISCUSSION}

\section{Interpretation of Outcrop Investigations of Lower Nuttall Sandstone and New River Formation Sandstones and Comparison to Climbing Literature}

The lower Nuttall Sandstone member is mechanically strong with an average of 54.4 which pushes the upper limit of strength that can be measured with a Schmidt Hammer of 55. Its strength does not vary much from climbed route to climbed route, as shown by Schmidt hammer readings (Table 4 and Appendix 2). Variations are controlled by presence or absence of goethite in secondary pores, the basal conglomerate, or the less thickly bedded top section. Areas with goethite in secondary pores tend to be mechanically stronger than "clean" sandstone, most likely because the clean sandstone has secondary porosity, whereas goethite fills secondary pore space along fractures. Olson et al. (2007) determined that quartz cement develops in host rock surrounding fractures, which corresponds to an increase in mechanical strength which is called induration. This is not an exact analogue of the goethite cement in secondary pores along fractures in the lower Nuttall Sandstone, however, it works to explain the increase in material strength in the goethite rich areas as development of relatively more cement in host rock surrounding fractures can lead to an increase in material strength. Since goethite preferentially precipitated along joints, and the blocks of lower Nuttall Sandstone fail along the same joints (Figure 20), faces exposed by block failure are commonly coated with resistant goethite (Figure 7). Locally, weathering of the sandstone behind areas with goethite as a secondary cement along fractures has caused flaking and development of desirable climbing features (Figure 21). Since joints containing goethite are typically at varying angles to each other, areas of goethite in secondary cement along 
fractures tend to be exposed in cross section (Figure 7). These areas of goethite can form positive features that are great holds for climbing (Figure 21). Thus, goethite containing areas are of utmost importance in the competence, resistance, and climbing desirability of the sandstone.

Remo (1999) showed the orientation of the New River follows known joint orientations in the region. This study shows all measured climbing route orientations are aligned to within $10^{\circ}$ of the same known joint orientations that Remo (1999) correlated with the orientation of the New River. Therefore, lower Nuttall Sandstone cliff-face orientations in the New River Gorge follow, and thus are controlled largely by, joint orientation. Joint spacing in the lower Nuttall Sandstone is relatively wide due to its massive bedding and physical properties. This spacing is important because, as joints are exaggerated by physical and chemical weathering, they commonly separate in an orientation parallel to the gorge orientation. Because the lower Nuttall Sandstone is so competent, this failure orientation leads to large blocks of the sandstone moving down the gorge walls, exposing fresh, unweathered faces for climbing.

According to Dr. Amy Hessl of the WVU Geology and Geography Department, who is an experienced climber, the competence of the lower Nuttall Sandstone affects climbing desirability because competent rock is safe rock (personal communication April 2011). Dr. Hessl says other popular climbed rock formations that she has personally climbed in the United States are not as competent as the lower Nuttall Sandstone, which contributes to its popularity among all levels of climbers (personal communication April 2011). She mentioned that climbers feel the lower Nuttall Sandstone does not often have bolts that fail and that gear placed in rock features will hold; also, they do not have to 
worry about pieces of rock failing from above or as climbers grab rock while climbing (personal communication April 2011).

Garlick (2009) states that climbing in NERI is due to bedding partings being eroded that lead to horizontal features, creating hand and foot holds. She does not mention vertical joints as being present in the lower Nuttall Sandstone. Contrary to this, results from this study indicate a lack of significant bedding partings in the lower Nuttall Sandstone and lack of weathering that make the sandstone competent and safe, as well as the presence of vertical joints and interesting surface features created by differential weathering behind goethite cemented areas are the main contributing factors to why the lower Nuttall Sandstone is popular among climbers.

Garlick (2009) mentions the lower Nuttall Sandstone and Corbin Sandstone of the Lee Formation, which is climbed in the Red River Gorge of Kentucky, are age equivalents and are both of fluvial origin. In her description, the Corbin Sandstone contains cavernous and honeycomb weathering, vertical cracks, horizontal bedding and cross-bedded partings, overhangs, and other unique surface features that contribute to its climbing desirability. Literature indicates the Corbin Sandstone has liesgangen (Greb and Mason 2005). Strachan (2007) describes case hardening, as well as the presence of liesegangen, in the Corbin Sandstone. The Corbin Sandstone is also described as being inconsistent due to changes in cement amount, grain size, and extent of weathering (Strachan 2007). In some areas it contains no surface features and cannot be climbed or toped out due to the upper portion lacking surface features, yet in other areas it is not well cemented and actively fails (Strachan 2007). The extent of weathering varies, which changes the amount and type of surface feature present, which may be related to 
aforementioned changes in cement and grain size (Strachan 2007). Thus, the Corbin Sandstone may be less consistent than the lower Nuttall Sandstone in NERI and thus, the Red River Gorge is not as popular of a climbing area as NERI. It would be an interesting direction for future work to compare and contrast the two sandstones.

Separation of blocks is influenced by differential weathering of the less mechanically strong and less resistant, highly porous basal conglomerate. In some areas where conglomeratic lenses occur in the sandstone, differential weathering of these lenses creates surface features desirable for climbing as "huecos" make hand and foot holds. Below the conglomerate is a shale that is even less resistant than the conglomerate and works to undermine blocks of the lower Nuttall Sandstone. When such blocks of the lower Nuttall Sandstone fail, planar vertical faces parallel or perpendicular to the gorge walls result. This pattern of failure has an effect on exposure age and therefore weathering; relatively fresh faces of lower Nuttall Sandstone are exposed, leaving less time for sandstone to be affected by surficial weathering, thereby leaving challenging, nearly vertical climbs with few surface features and bedding partings to cause competence issues.

Variation in bedding thickness in the lower Nuttall Sandstone may make certain localities more desirable for climbing. The top $3 \mathrm{~m}$ of the lower Nuttall Sandstone is generally more thinly bedded than the massive section below and contains obvious bedding partings. At many climbing routes, separation and subsequent failure along bedding partings in this $3 \mathrm{~m}$ upper section leads to blocks of the massively bedded middle portion of the lower Nuttall Sandstone failing, creating overhangs desirable for expert climbers (Figure 22). At other climbing routes, this more thinly bedded section has failed 
before the massive blocks below, creating shorter climbs without overhangs suited for less expert climbers.

Although not extremely different from NERI outcrops of lower Nuttall Sandstone, bedding is much thinner at Kanawha Falls. There is not massively bedded sandstone in the middle of the section, and there are channel scours and shaley intervals that make the rock less competent and allow more diverse differential weathering throughout the unit. There is no shale or basal conglomerate between the coalesced upper and lower members of the Nuttall Sandstone at Kanawha Falls. The sandstone is near river level and does not appear to contain goethite in secondary pores, so there is not the same undercutting block failure mechanism to produce fresh, goethite containing faces.

The upper Raleigh Sandstone is not climbed in NERI and at Grandview, WV because massively bedded, competent rock is localized with less competent rock above and below. Specifically, pronounced bedding with obvious partings, interbedded shale, and conglomeratic lenses make the upper Raleigh Sandstone less competent and less desirable for climbing than the lower Nuttall Sandstone. In GARI and at Grandview, localized areas of massive beds occur but could not be safely climbed because they are not laterally continuous, and non-competent, thinly bedded sandstone beds occur above and below the massive beds. At Grandview, typical bedding thickness is $0.6 \mathrm{~m}$ with erosion along partings, leading to the upper Raleigh Sandstone failing as relatively small blocks. Rapidly weathering conglomeratic layers common in the middle of the upper Raleigh Sandstone lead to boulder sized failures from the outcrop. The conglomerate weathers at a faster rate than the sandstone.

Similar to the upper Raleigh Sandstone, the scarcity of climbing routes in the 
Guyandot sandstone is related to bedding because the outcrops have thinner, less consistent bedding. The Guyandot sandstone outcrop near Bridge Buttress with two bolted climbs has $0.15 \mathrm{~m}$ to $0.3 \mathrm{~m}$ thick bedding with obvious partings up to $0.03 \mathrm{~m}$ thick. The Schmidt hammer value of 60.0 on the Guyandot sandstone is mechanically stronger than the non-goethite containing massive middle portion of the lower Nuttall Sandstone (Table 4) but bedding characteristics are more important to climbing than mechanical strength; according to local climbing guides, thin bedding with pronounced partings makes for such easy climbs that serious climbers are not interested.

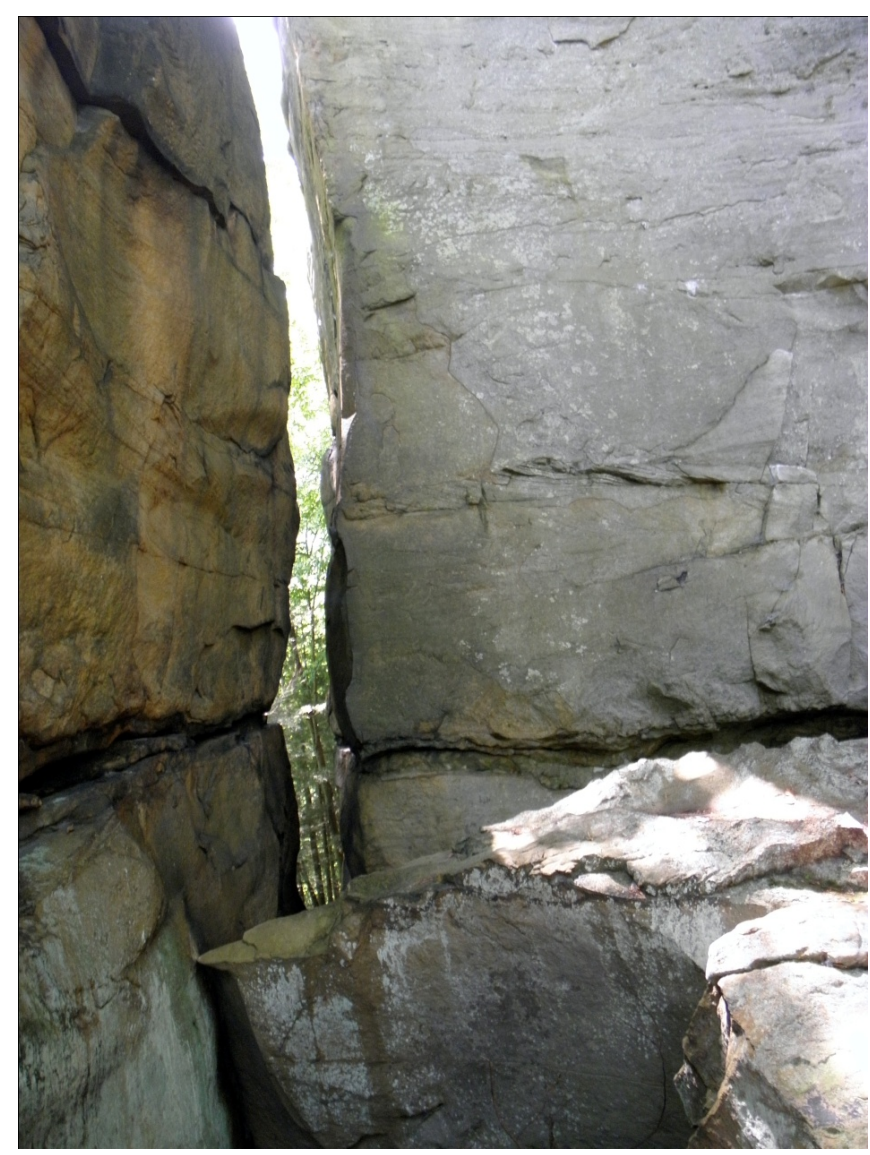

Figure 20: Large block on right is separated from bedrock outcrop by an expanded joint at Kaymoor. 


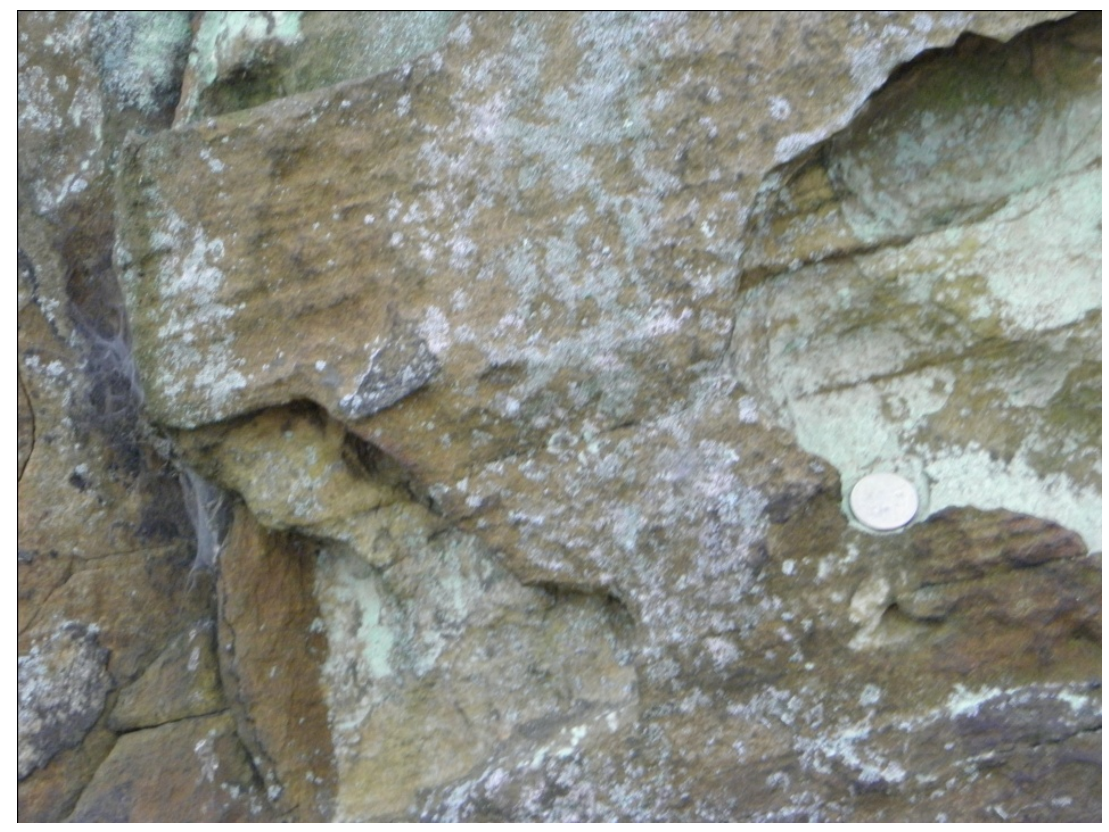

Figure 21: Weathering has caused partial flaking of are with goethite in secondary pores, creating climbing holds. Notice quarter for scale. 


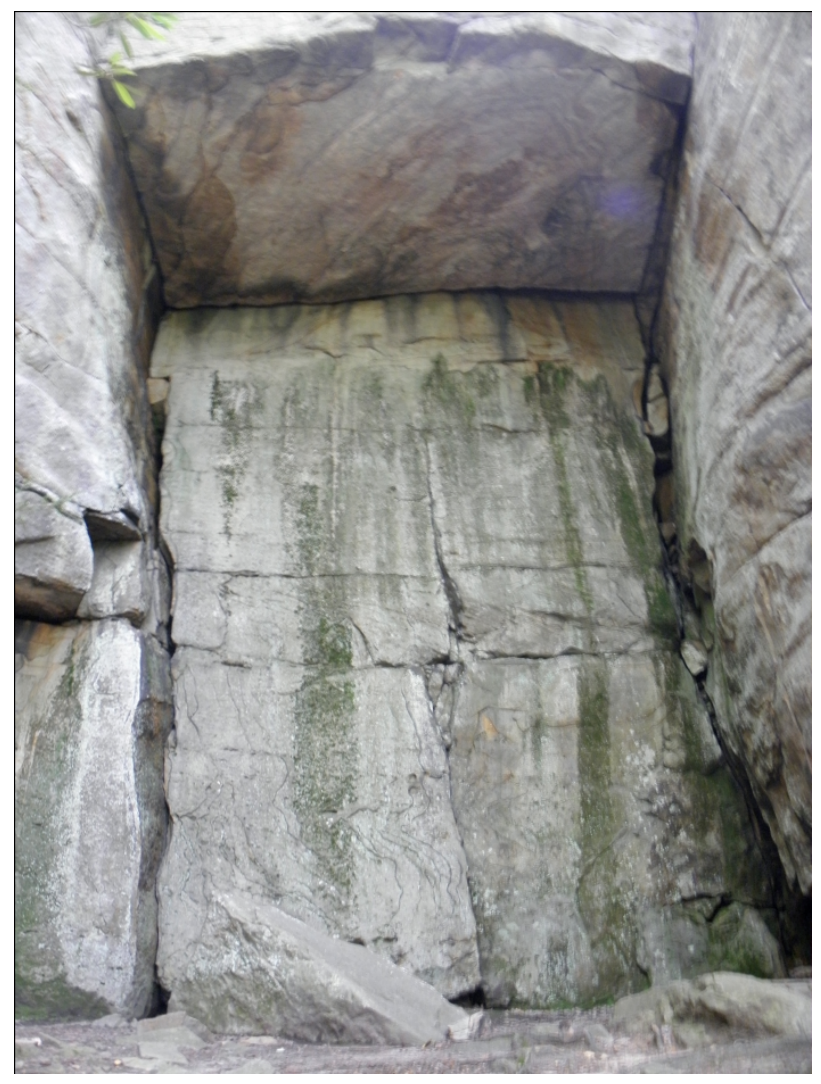

Figure 22: Differential failure of blocks below thinly bedded top section at Bridge Buttress.

\section{Interpretation of Mineralogy}

Origin of Minerals in Lower Nuttall Sandstone

Tourmaline, as indicated by the dravite spike on the XRD/XRF results (Table 7) and by visual inspection of thin sections, is almost certainly reworked from earlier arenaceous rocks (Greensmith 1989, Pettijohn et al. 1987). Ilmenite, other titanium minerals, and ulvöspinel indicate reworked sedimentary rocks (Greensmith 1989, Pettijohn et, al 1987). Typicall, monocrystalline quartz is originally from igneous rocks or coarsely banded gneisses, and polycrystalline is originally from metamorphic rocks 
such as thinly banded gneisses and mica schist (Greensmith 1989, Pettijohn et. al 1987).

The exact source of grains in the lower Nuttall Sandstone is unknown. Visual interpretation showed quartz grains in thin sections were abraded heavily, indicating high-energy conditions and/or long distance transport (Greensmith 1989, Pettijohn et. al 1987). Whether the source terrain for these sediments was more cratonic from the north or orogenic from the Appalachians to the east is still debated.

Although XRD/XRF analysis identified arsenopyrite (Table 7) in the lower Nuttall Sandstone in a sample taken from an area with goethite in secondary pores along a fracture, XRD analysis did not identify arsenopyrite in an area devoid of goethite. Pyrite was seen in thin section in an area devoid of goethite. SEM/EDX element mapping shows arsenic as present in portions of the sandstone devoid of goethite as well as in areas with goethite. The SEM/EDX indicated sulfur in the element mapping of an area with goethite in secondary pores although only for a brief time during the ten minutes it was running, indicating sulfur may be present in trace amounts in the area with goethite, although not necessarily in association with arsenic since arsenic is present in both goethite containing and non-goethite containing areas. Europium and neodymium occurred throughout the sample, but not in the area with goethite cement, perhaps indicating fluid that precipitated the goethite in the secondary pores along fractures removed the two metals.

Analysis of Primary and Secondary Cement in Lower Nuttall Sandstone and Comparison of Goethite to Case Hardening and Concretions

Dust rims are absent in the lower Nuttall Sandstone thin sections analyzed in this study. Therefore, there is no optical difference between cement and framework grains 
(Pettijohn et al. 1987). This makes it difficult to interpret cement in the lower Nuttall Sandstone. Previous studies have used cathodoluminescence to determine cement from framework grains (Evans et. al 1994, Bernet et al. 2007), which could be an area of further work in the lower Nuttall Sandstone. Reed et al. (2005b) proposes clay alteration as a source for quartz cement in the New River Formation because the formation was exposed to temperatures where smectite is altered to illite, which would release silica that could precipitate as cement. He also posits that cement could have precipitated as fluid rich with silica sourced from the hinterland or from low-grade metamorphism in other locations moved through the New River Formation. The presence of stylolites in thin sections analyzed in this study may indicate some cement in the lower Nuttall Sandstone is from pressure dissolution (Heald 1955, Heald 1959, Mitra and Beard 1980, Greensmith 1989).

Iron oxide commonly occurs as cement surrounding framework grains (Heim et al. 2006) that can be locally encased from later quartz growth (Greensmith 1989). Secondary quartz can also become stained by iron oxide, so sometimes there are different periods of iron oxide or quartz growth (Greensmith 1989, Pettijohn et al. 1987). Such phenomena do not occur in the lower Nuttall Sandstone, as there is no banding and goethite is more than just a stain. Iron oxide can be diagenetic and form in the basin of deposition as detrital and authigenic iron bearing clay minerals break down (Greensmith 1989, Wolf \& Chilingarian 1994, Pettijohn et al. 1987). Clays readily absorb iron, and chlorite and smectite can contain iron in their lattices (Greensmith 1989, Pettijohn et al. 1987). XRD results (Table 7) show no smectite or chlorite in the rock, so this method of introduction is unlikely. Arsenopyrite and pyrite in black shales above and below the 
lower Nuttall Sandstone or in lithic fragments of the sandstone itself may be the source of goethite, although XRD results indicate the surrounding shales are devoid of pyrite and arsenopyrite. If the goethite is locally sourced, a possible method for its precipitation is mentioned by Wolf \& Chilingarian (1994) and Pettijohn et al. (1987) and is outlined by Greensmith (1989): in a humid climate, iron may be released by hydrolysis into capillary pore water in rock exposed to the atmosphere. When such a situation occurs in the presence of a positive $\mathrm{eH}$, iron is progressively oxidized and precipitated into pore space as goethite or hematite when it dewaters, which may lead to iron oxide concentrations of 1 to $5 \%$ in the host rock (Greensmith 1989). This 1 to $5 \%$ iron oxide range was observed by XRD in the goethite containing areas; yet, XRD results indicate the lower Nuttall Sandstone and surrounding shale are devoid of pyrite or other major iron bearing minerals. Thus, even though goethite occurs in secondary pores in joints that would have more interaction with the atmosphere than the interior of blocks, this hypothesis of goethite source is not completely supported as a local source was not identified, although coal in the New River Gorge could be the source of goethite via pyrite oxidation. The iron is most likely not supergene in nature, as studies have indicated that supergene ferruginous deposits contain upwards of $10 \%$ iron (Greensmith 1989). The iron might have been far-sourced. If the iron is far-sourced, it could have been carried as dissolved ferrous salts in subsurface acidic to neutral waters, but when at the surface, the water was aerated and the salt hydrolyzed and oxidized, forming iron hydroxide (Greensmith 1989). Rivers can transport iron as ferric oxide hydrosols that are stable because of colloidal substances adsorbed on clay minerals (Greensmith 1989, Wolf \& Chilingarian 1994). The colloids will have a positive charge so the iron will not precipitate, as long as 
electrolytes are low and there are not many negatively charged colloids (Greensmith 1989).

As aerated water or air itself was introduced along the chemically active joints, the goethite in groundwater or from within the lower Nuttall Sandstone could have precipitated in the joints preferentially. This method of precipitation is similar to the way liesegangen and other concretions of goethite form (Fu et al. 1994, Pary 2001). However, liesegangen form in circular rings and concretions are not planar (Pary 2011) as the goethite containing areas are in the lower Nuttall Sandstone. Thus, it would be imprecise to refer to the goethite cemented areas in the lower Nuttall Sandstone as liesgangen or concretions. It is also important to make the distinction between goethite cement in the lower Nuttall Sandstone and goethite in case hardening, although case hardening involving goethite often has similar proposed methods of precipitation (Fu et al. 1994, Price \& Velbel 2000); case hardening refers to induration of rock surfaces and does not imply presence of secondary minerals in host rock (Glossary of Geology 1987). Although induration is occurring in the lower Nutall Sandstone containing goethite, goethite does not occur alone on the surface of joint planes, but rather is restricted to secondary pores within the host rock adjacent to vertical joints. Due to lack of surface expression of areas composed of entirely of goethite as would exist if the process was case hardening, it is imprecise to refer to the goethite containing areas as case hardening.

Goethite in secondary pores was also seen in outcrop in areas where conglomeratic lenses have been preferentially weathered away due to higher permeability, perhaps indicating there is an association with goethite precipitation and areas of high porosity and permeability in addition to joint planes. 


\section{Analysis and Comparison of Minerology and Properties of Sandstones from Thin}

\section{Sections}

Thin sections indicate the basal conglomerate, when compared with the rest of the lower Nuttall Sandstone, contains more polycrystalline quartz, rock fragments, and secondary porosity (Table 6), which work to make it less resistant to weathering, thus contributing to block failure of the overlying sandstone as it weathers out from beneath. The upper, thinner bedded section of the lower Nuttall Sandstone contains the most micaceous rock fragments, and has pronounced bedding. The massively bedded middle section tends to be well sorted and medium grained, with small amounts of rock fragments, which causes any bedding partings to weather uniformly with the rest of the rock and not be pronounced, especially where blocks are encased in a $3 \mathrm{~cm}$ area of goethite in secondary pores.

Thin sections indicate the entire lower Nuttall Sandstone is grain supported, and grains have undergone compaction, causing quartz regrowth at grain boundaries, generating primary cement in the rock. Quartz grain boundaries in lower Nuttall Sandstone thin sections are concavo-convex, which indicates pressure solution (Pettijohn et al. 1987). A stylolite was also observed in Thin Section 5, which indicates pressure dissolution. Micaceous rock fragments in the lower Nuttall Sandstone thin sections commonly appear to be wrapped around quartz grains, which, according to Greensmith (1989), can occur due to deformation during compaction. Mica, clays, and lithic fragments can also aid this process, as they bend around the quartz grains and act as lubricants. 
Secondary porosity indicates grains of a preexisting material have weathered out of the sandstone. Because tectonic joints are more chemically active and susceptible to fluid flow (Price \& Velbel 2000, Olson et al. 2007), the host rock adjacent to joints contains goethite in secondary pore space, whereas the interior of lower Nuttall Sandstone blocks have unfilled secondary pores. The presence of secondary goethite cement in the areas adjacent to joints makes them more resistant to weathering because there is little porosity and therefore low permeability (Fu et al. 1994, Price \& Velbel 2000). The goethite containing areas along fractures also gave higher readings on the Schmidt hammer due and thus are mechanically stronger, which as discussed previously, is due to induration caused by the presence of more cement in host rock surrounding fractures similar to Olson et al. (2007).

Mineralogy and bedding in other New River Sandstones differ from the lower Nuttall Sandstone and affect climbing desirability. The upper Raleigh Sandstone contains more micacous rock fragments, is less resistant, is not as well sorted, and is finer grained than the lower Nuttall Sandstone. Thus, the upper Raleigh is not as prolific of a cliff former, although if bedding were more continuous and competent, it would be more desirable for climbing. The Guyandot sandstone also has more micaceous rock fragments than the lower Nuttall Sandstone although it is mechanically stronger than the lower Nuttall Sandstone due to being well sorted and compacted. Again, if its bedding were thicker and less pronounced, it would be more desirable for expert climbing. The upper Nuttall Sandstone has a high amount of rock fragments and is coarser grained than the lower Nuttall Sandstone, which make it less resistant due to increased pore space and 
permeability. The lower Nuttall Sandstone thin section from $70 \mathrm{~km}$ north of Fayetteville has similar mineralogy to the lower Nuttall Sandstone in NERI.

Due to lack of well-developed outcrops and limited core availability, this study could not determine if there is goethite as secondary cement along joints, if there are similar joints, or if there is a massively bedded middle section similar to the lower Nuttall Sandstone in NERI in the northern lower Nuttall Sandstone. Therefore, it is not possible to determine if the lower Nuttall Sandstone could be climbed to the north. Thus, the lower Nuttall Sandstone in NERI is a unique resource.

\section{Analysis of Statistical Results}

There was a significant positive correlation between level of surface features of bolted and non-bolted climbs and star rating of climbs at $p=0.016$ (Table 8). Star rating is a climber assigned value of quality. This correlation indicates the level of surface features at an outcrop is a good indicator of how many stars a climb will be assigned by the climbing community, since as stars go up, the level of surface features goes up. In other words, climbers like routes that have interesting surface features most, such as bedding partings and flakes, so long as surface features and bedding partings are not at extreme levels, as they are in the upper Raleigh Sandstone and Guyandot sandstone, which as Filer and Kleinschmidt (1987) discussed, is not good for climbing rock. "Trad" style climbing requires features into which climbers can install cams and other gear, and sport style climbing requires surface features for hand and foot holds. This correlation may prove important for prediction of climber preferences at undeveloped climbing areas, although there are very few areas of outcrop in NERI of the lower Nuttall Sandstone that are not already climbed. 
As number of surface features go up, climbing grade or difficulty goes up in nonbolted and bolted climbs ( $\mathrm{p}=.024)$. Although counter-intuitive since an extremely high level of surface features may make for an easier climb as in the Guyandot sandstone, in areas where a significant amount of bedding partings are present in the lower Nuttall Sandstone, block failure leads to the creation of overhangs and a positive slope of the rock face. This makes climbs more difficult and desirable for expert climbing. For this reason, it may be interesting in the future to measure slope and extent of overhangs and correlate with surface features, however in this study, overhangs were only considered as present or absent. Some variables loosely correlate with grade, mechanical strength and orientation (Table 8). There is not an obvious pattern that develops in specific types of climbs, so although these may indicate real patterns, especially considering the variability in Schmidt hammer readings, they need to be examined in more detail and at more sites before any significant patterns can be obtained.

Popularity of top-roped climbs may be different from other types of climbs and this variability in purpose may make them anomalous. Analysis on climbs that contain anchor bolts only at the top between level of surface features and grade or stars shows a negative rank coefficient, indicating that as level of surface features goes up, the number of stars assigned goes down, suggesting anchored climbs are fundamentally different from bolted and non-bolted climbs. Perhaps they were not fully bolted because the climb was not worth finishing bolting or because the rock was too difficult to bolt. If there are too many surface features, the climb may fail, or become "chossy" in climbing lingo, or be difficult to bolt due to lack of stable places to put bolts. If a climb was not bolted because it was chossy, and therefore, had an extremely high number of surface features 
leading to failure, then the level of stars would be low. The anomalous correlation could also be an artifact of access or some other variable. For example, the anchored climbs are not bolted and are not popular because they are difficult to access. It is also possible that anchored climbs have different purposes than bolted and unbolted climbs; for example, some were anchored just to have a rappel point, so the number of surface features is not important to the star rating. Many anchored climbs are used for a different style of climbing, top roping, so top ropers may have different rock preferences than "trad" or sport climbers. Top ropers may be willing to take more risks because it is a safer style of climbing, so the level of surface features is less important. Top ropers could be more novice climbers, or prefer top roping locations that have easy top access, thus interfering with a clear statistical signal. An anchor could have been added because the NPS was concerned with people tying anchors to trees at particular locations which may also interfere with analysis. 


\section{CONCLUSIONS}

\section{Why the Lower Nuttall Sandstone is More Desirable for Climbing than other New River Sandstones}

The lower Nuttall Sandstone is a cliff former in the New River Gorge, and Remo (1999) found a correlation between tectonic joint orientation and river orientation. Based on field observations, this contributes significantly to climbing desirability in NERI by allowing blocks of the Nuttall to fail in a pattern related to both, creating flat cliff sections along the walls that contain many of the climbing routes. The less resistant basal conglomerate and shale below the competent portions of the lower Nuttall also contribute to this mechanism, as they are eroded more quickly, undercutting the heavy blocks of the competent lower Nuttall Sandstone above. This continual failure of the blocks on a geologic timescale keeps a relatively fresh, unweathered surface of cliff available to climb. As the blocks are partially encompassed by a $3 \mathrm{~cm}$ resistant portion where goethite has preferentially filled in secondary pores adjacent to tectonic joints, they are even more resistant to weathering than a typical quartz arenite. This makes the lower Nuttall Sandstone a very safe and competent formation for climbers. Surface features that are great for hand and foot holds and for gear are created by weathering of conglomeratic lenses creating what climbers call "huecos", by differential weathering behind goethite containing areas adjacent to joints which creates flakes, and by differences in bedding in the top portion of the lower Nuttall Sandstone that may lead to overhangs. Joints also add to climbing appeal by creating holds for feet, hands, and gear. The upper Raleigh Sandstone is not climbed because there is a lack of continuous, competent outcrops. The Guyandot sandstone is not climbed because pronounced bedding, although not to the 
point of causing failure as in the upper Raleigh Sandstone, leads to climbs with many hand and footholds that make for easy climbs that are not desirable for the experts that frequent NERI. Finally, the almost unlimited number of climbs along the extensive cliffs allow for thousands of people to climb great climbs at any given time, all with beautiful views of the New River. 


\section{REFERENCES}

ASTM D 5873-05, 2008, Standard Test Method for Determination of Rock Hardness. Copyright ASTM International, Used with permission from ASTM International, available for purchase at www.astm.org, 3 p.

Arkle, T., Jr.1974, "Stratigraphy of the Pennsylvanian and Permian systems of the central Appalachians; Carboniferous of the southeastern United States", Special Paper Geological Society of America, no. 148, Geological Society of America, Boulder, Colorado, United States, p. 5-29.

Arndt, H.H., Englund, K.J. \& Gillespie, W.H. 1979, "Stop descriptions; third day; Proposed Pennsylvanian System stratotype, Virginia and West Virginia", $A G I$ Selected Guidebook Series, no. 1, American Geological Institute, Falls Church, Virginia, United States of America, p. 15-25.

Bennington, J.B. 2002, "Eustacy in cyclothems is masked by loss of marine biofacies with increasing proximity to a detrital source; an example from the central Appalachian Basin, U.S.A; Carboniferous and Permian of the world; XIV ICCP proceedings", Memoir - Canadian Society of Petroleum Geologists, vol. 19, Canadian Society of Petroleum Geologists, Calgary, Alberta, Canada, p. 12-21.

Bernet, M., Kapoutsos, D., Bassett, K. 2007, ’'Diagenesis and provenance of Silurian quartz arenites in south-eastern New York State", Sedimentary Geology, Elsevier, Amsterdam, Netherlands, vol. 201 no. 1-2, p. 43-55.

Beuthin, J.D. 1994, "A sub-Pennsylvanian paleovalley system in the Central Appalachian Basin and its implications for tectonic and eustatic controls on the origin of the regional Mississippian-Pennsylvanian unconformity; Tectonic and eustatic controls on sedimentary cycles", Concepts in Sedimentology and Paleontology, vol. 4, Society for Sedimentary Geology, Tulsa, Oklahoma, United States of America, p. 107-120.

Blair, T.C. \& McPherson, J.G. 1999, "Grain-size and textural classification of coarse sedimentary particles", Journal of Sedimentary Research, vol. 69, no. 1, Society of Economic Paleontologists and Mineralogists, Tulsa, Oklahoma, United States of America, p. 6-19.

Blake, B.M., Jr. 2009. "Carboniferious paleobotany and paleoclimatology of the central Appalachian basin", West Virginia, U.S.A. Unpublished dissertation. Morgantown, West Virginia University, p. 1-240.

Blake, B.M., Jr., Cecil, C.B., Eble, C.F., Fedorko, N. \& Grady, W.C. 1992, Stratigraphy of the Lower and Middle Pennsylvanian series in West Virginia; Paleoclimate controls on Carboniferous sedimentation and cyclic stratigraphy in the Appalachian Basin, United States Geological Survey, Reston, Virginia, United States of America, p. 102-114. 
Blake, B.M., Jr., Martino, R.L., Grady, W.C. \& Eble, C.F. 1998, "Revised megafloral biostratigraphy of the New River and Kanawha formations (Pottsville Group; Lower and Middle Pennsylvanian) in southern West Virginia" in Coal geology, paleobotany, and regional stratigraphy of the middle part of the Kanawha Formation, southern West Virginia, Geological Society of America, Southeast Section, Denver, Colorado, United States of America, p. 41-56.

Blake, B.M., Jr. \& Beuthin, J.D. 2008, "Deciphering the Mid-Carboniferous eustatic event in the central Appalachian foreland basin, southern West Virginia, USA; Resolving the late Paleozoic ice age in time and space", Special Paper-Geological Society of America, vol. 441, Geological Society of America, Boulder, Colorado, United States of America p. 249-260.

Burgin, B. 1986,"Climbing in the New River Gorge," Climbing Magazine, vol. 32, no. 85, Boulder, Colorado, United States of America, p 32-33.

Cecil, C.B., Eble, C. F., Fedorko, N., Blake, B.M., \& Grady, W.C. 1992, Paleoclimate controls on Carboniferous sedimentation and cyclic stratigraphy in the Appalachian Basin, United States Geological Survey, Reston, Virginia, United States of America, p. 43-44.

Chesnut, D. 1997, "Eustatic and tectonic control of deposition of the Lower and Middle Pennsylvanian strata of the Central Appalachian Basin; Proceedings of the XIII international congress on The Carboniferous and Permian", Prace Panstwowego Instytutu Geologicznego (1988), vol. 157, Part 2, Wydawnictwa Geologiczne, Warsaw, Poland, p. 33-41.

Clark, P. 2010, "Assessing the sustainable limits of climbing in the New River Gorge", WV, Unpublished Geography M.A. thesis proposal, Morgantown, West Virginia, West Virginia University, $55 \mathrm{p}$.

Colton, G.W., Perry, W.J., Mackenzie, J.D. 1976, Joint Trends in the Appalachian Basin: United States Geological Survey Open-file Report 81-837, United States Geological Survey, Reston, Virginia, United States of America, 4 sheets.

Davis, J.C. 2002. Statistics and Data Analysis in Geology, 3rd edition, John Wiley and Sons, New York City, New York, United State of America, 638p.

Davis, G.H. \& Reynolds, S.J. 1996, Structural geology of rocks and regions, John Wiley and Sons, New York, New York, United States of America, 776 p.

Donaldson, A.C., Renton, J.J. \& Presley, M.W. 1985, "Pennsylvanian deposystems and paleoclimates of the Appalachians; Paleoclimatic controls on coal resources of the Pennsylvanian System of North America", International Journal of Coal Geology, vol. 5, no. 1-2, Elsevier, Amsterdam, Netherlands, p. 167-193. 
Donaldson, A.C. \& Shumaker, R.C. 1981, "Late Paleozoic molasse of Central Appalachians; Sedimentation and tectonics in alluvial basins", Special Paper Geological Association of Canada, Geological Association of Canada, Toronto, Ontario, Canada, no. 23, p. 99-124.

Englund, K.J. 1979, "Mississippian System and lower series of the Pennsylvanian System in the proposed Pennsylvanian System stratotype area; Proposed Pennsylvanian System stratotype, Virginia and West Virginia", AGI Selected Guidebook Series, no. 1, American Geological Institute, Falls Church, Virginia, United States of America, p. 69-72.

Englund, K.J., Cecil, C.B. \& Stricker, G.D. 1979, "Depositional environments of the Mississippian System and Lower Pennsylvanian Series in proposed Pennsylvanian System stratotype area; Proposed Pennsylvanian System stratotype, Virginia and West Virginia", AGI Selected Guidebook Series, no. 1, American Geological Institute, Falls Church, Virginia, United States of America, p. 113-114.

Englund, K.J., Cecil, C.B., Stricker, G.D. \& Warlow, R.C. 1976, "Carboniferous stratigraphy of southwestern Virginia and southern West Virginia", Guidebook Geological Society of America, Southeastern Section, Field trip guidebook No.3, Geological Society of America, Boulder, Colorado, United States of America, 40 p.

Englund, K.J., Lesure, F.G., Davies, W.E., King, E.R. \& Perry, W.J. 1977, Mineral resource appraisal of the New River gorge, Fayette, Raleigh, and Summers counties, West Virginia, United States Geological Survey Open File Report 77-76, Reston, Virginia, United States of America, 84 p.

Englund, K.J., Pfefferkorn, H.W. \& Henry, T.W. 1979, "Stop descriptions; second day; Proposed Pennsylvanian System stratotype, Virginia and West Virginia", AGI Selected Guidebook Series, no. 1, American Geological Institute, Falls Church, Virginia, United States of America, p. 7-12.

Englund, K.J., Gillespie, W.H., Cecil, C.B., Windolph, John F, Jr \& Crawford, T.J. 1986, Characteristics of the Mississippian-Pennsylvanian boundary and associated coalbearing rocks in the Southern Appalachians, United States Geological Survey, Reston, Virginia, United States of America, p. 1-8.

Englund, K.J., Wnuk, C., Gillespie, W.H. \& Pfefferkorn, H.W. 2002, "A Pennsylvanian system stratotype; Carboniferous and Permian of the world; XIV ICCP proceedings", Memoir - Canadian Society of Petroleum Geologists, vol. 19, Canadian Society of Petroleum Geologists, Calgary, Alberta, Canada, p. 684-695.

Evans, F. B. 2008, "Magnetic characteristics of Carboniferous continental depositional systems: Implication for recognition of deposition hiatuses." Unpublished thesis. Virginia Polytechnic Institute and State University. Blacksburg, Virginia, United States of America, $61 \mathrm{p}$. 
Evans, J., Hogg, A. J., Hopkins, M. S., \& Howarth, R.J. 1994, "Quantification of quartz cements using combined SEM, CL, and image analysis", Journal of Sedimentary Research, Tulsa, Oklahoma, United States of America, vol. 64, no 2, p. 334-338.

Filer, J.K. \& Kleinschmidt, R.F. 1987, "The geology of rock climbing", Mountain State Geology, vol. 1987, West Virginia Geological and Economic Survey, Morgantown, West Virginia, United States of America, p. 10-17.

Forney Inc. Concrete Test Hammer Type N. Forney Inc., Wampum, Pennsylvania, United States of America, 3 p.

Fu, L., Milliken, K.L., \& Sharp, J.M. Jr. 1994. "Porosity and permeability variations in fractured and Liesegang-banded Breathitt sandstones (Middle Pennyslvanian), eastern Kentucky: diagenetic controls and implications for modeling dual-porosity systems", Journal of Hydrology, Elsevier, Amsterdam, Netherlands, vol. 154, p. $351-381$.

Galloway, M. C. B., Padgett, G., Carpenter, W.D. \& Ferm, J.C. 1979, "Some general characteristics of the Pocahontas and New River formations" in Carboniferous depositional environments in the Appalachian region, J.C. Ferm, J.C. Horne, G.A. Weisenfluh \& J.R. Staub, eds. University of South Carolina, Department of Geology; Carolina Coal Group, Columbia, South Carolina, United States of America, p. 221-228.

Garlick, S. 2009, Flakes, Jugs \& Splitter, Morris Book Publishing, Guilford, Connecticut, United State of America, 210 p.

Bates, R.L., and Jackson, J.A. 1987, eds., Glossary of Geology, third edition, American Geological Institute, Alexandria, Virginia, United States of America, 788 p.

Greb, S.F. \& Chesnut, D.R. 1996, "Lower and lower Middle Pennsylvanian fluvial to estuarine deposition, central Appalachian basin: Effects of eustasy, tectonics, and climate", Bulletin of the Geological Society of America, vol. 108, no. 3, Geological Society of America, Boulder, Colorado, United States, p. 303-317.

Greb, S.F. \& Mason, C.E. 2005, "Geology of the Red River Gorge Geological Area and Natural Bridge State Resort Park", 42nd Annual Meeting of the American Institute of Professional Geologists Field Trip Guidebook, American Institute of Professional Geologists, Thornton, Colorado, United State of America, 43 p.

Greensmith, J.T. 1989, Petrology of the sedimentary rocks, Unwin Hyman, London, Great Britain, 262 p.

Heald, M.T. 1955, "Stylolites in Sandstone", Journal of Geology, University of Chicago Press, Chicago, Illinois, United States of America, vol. 63, no. 2, p. 101-114. 
Heald, M.T. 1959, "Significance of stylolites in permeable sandstones", Journal of Sedimentary Petrology, Society of Economic Paleontologists and Mineralogists, Tulsa, Oklahoma, United State of America, vol. 29, no. 2, p. 251-253.

Heim, J.A., Vasconcelos, P.M., Shuster, D.L., Farley, K.A., and Broadbent, G.C. 2006, "Dating palaeochannel iron ore by (U-Th)/He analysis of supergene goethite, Hamersley Province, Australia", Geology, University of Chicago Press, Chicago, Illinois, United States of America, vol. 34, no. 3, p. 173-176.

Hennen, R.V. 1919, “Fayette County”, West Virginia Geologic and Economic Survey, Morgantown, West Virginia, United States of America, 1002 p.

Henry, T.W., Englund, K.J., Johnson, P.L., Mory, P.C. \& Windolph, J.F.,Jr. 1981, Description and correlation of core from five deep drill holes in Carboniferous rocks along the New River gorge, West Virginia, United States Geological Survey, Reston, Virginia, United States of America, $89 \mathrm{p}$.

Horne, J.C. \& Ferm, J.C. 1978, Carboniferous depositional environments; eastern Kentucky and southern West Virginia, University of South Carolina, Department of Geology, Columbia, South Carolina, United States of America, 129 p.

Lessing, P. 1986, "Geology of the New River Gorge", Mountain State Geology, vol. 1986, West Virginia Geological and Economic Survey, Morgantown, WV, United States of America, p. 48-55.

Korus, J.T. 2002, “The Lower Pennsylvanian New River Formation, a non-marine record of glacioeustasy in a foreland basin", Unpublished thesis. Virginia Polytechnic Institute and State University, Blacksburg, Virginia, United States of America, 54 p.

Korus, J.T., Kvale, E.P., Eriksson, K.A. \& Joeckel, R.M. 2008, "Compound paleovalley fills in the Lower Pennsylvanian New River Formation, West Virginia, USA", Sedimentary Geology, vol. 208, no. 1-2, Elsevier, Amsterdam, Netherlands, p. 1526.

Kottlowski, F. E. 1965, Measuring stratigraphic sections: Holt, Rinehart, and Winston, New York, New York, United States of America, 253 p.

Kulander, B.R., and Dean, D.L.1993, Coal-cleat domains and domain boundaries in the Allegheny Plateau of West Virginia: American Association of Petroleum Geologists Bulletin, v. 77, no. 8, American Association of Petroleum Geologists, Tulsa, Oklahoma, United States of America, p. 1374-1388.

Mills, H.H. 1990, "Geologic and topographic controls on the rapids of the New River gorge, West Virginia", Southeastern Geology, vol. 31, no. 1, Duke University, Department of Geology, Durham, North Carolina, United States of America, p. 4562. 
Mitra, S., \& Beard, W. C. 1980, "Theoretical models of porosity reduction by pressure solution for well-sorted sandstones", Journal of Sedimentary Petrology, Society of Economic Paleontologists and Mineralogists, Tulsa, Oklahoma, United State of America, vol. 50, no. 4, p. 1347-1360.

National Park Service. 2006, Nature and Science (updated on July 25, 2006), available at http://www.nps.gov/neri/naturescience/, viewed on 9/20/2010.

Olson, J. E., Laubach, S. E., \& Lander, R. L. 2007, “Combining diagenesis and mechanics to quantify fracture aperture distributions and fracture pattern permeability": In Lonergan, L., Jolley, R.J., Sanderson, D.J. , Rawnsley, K., eds., Fractured Reservoirs, Geological Society of London Special Publication 270, London, Great Britain, p. 97-112.

Parry, W.T. 2011, "Composition, nucleation, and growth of iron oxide concretions", Sedimentary Geology, Elsevier, Amsterdam, Netherlands vol. 233, p. 53-68.

Perkins, D. 2002, Mineralogy, 2nd edition, Prentice Hall, New Jersey, United States of America, $483 \mathrm{p}$.

Pettijohn, F.J., Potter, P.E. \& Siever, R. 1987, Sand and Sandstone, Springer-Verlag, New York, New York, United States of America, 370 p.

Price, J.R., \& Velbel, M.A. 2000, "Weathering of the Eaton Sandstone (Pennsylvanian), Grand Ledge, Michigan: Geochemical mass-balance and implications for reservoir properties beneath unconformities", Journal of Sedimentary Research, Tulsa, Oklahoma, United States of America, vol. 70, no. 5, p. 1118-1128.

Reed, J.S. 2003, "Thermal and diagenetic evolution of Carboniferous sandstones, central Appalachian basin". Unpublished dissertation. Virginia Polytechnic Institute and State University. Blacksburg, Virginia, United States of America, 115 p.

Reed, J.S., Spotila, J.A., Eriksson, K.A. \& Bodnar, R.J. 2005a, "Burial and exhumation history of Pennsylvanian strata, central Appalachian basin; an integrated study", Basin Research, vol. 17, no. 2, Blackwell Science, Oxford, Great Britain, p. 259268.

Reed, J.S., Eriksson, K.A. \& Kowalewski, M. 2005b, "Climatic, depositional and burial controls on diagenesis of Appalachian Carboniferous sandstones; qualitative and quantitative methods", Sedimentary Geology, vol. 176, no. 3-4, Elsevier, Amsterdam, Netherlands, p. 225-246.

Remo, J.W.F. 1999, Geologic Controls on Mass Movement in the New River Gorge, West Virginia, unpublished M.S. Thesis: Morgantown, West Virginia, United State of America, West Virginia University, 107 p. 
Rice, C.L. 1985, "Terrestrial vs. marine depositional model; a new assessment of subsurface Lower Pennsylvanian rocks of southwestern Virginia", Geology (Boulder), vol. 13, no. 11, Geological Society of America, Boulder, Colorado, United States of America, p. 786-789.

Rice, C.L., Schwietering, J.F. \& United States Geological Survey. 1988, Fluvial deposition in the Central Appalachians during the Early Pennsylvanian; Evolution of sedimentary basins; Appalachian Basin, United States Geological Survey, Reston, Virginia, United States of America, p. B1-B10.

Samuels, M.L. \&. Witmer, J.A. 2003, Statistics for the life sciences, Prentice Hall, Upper Saddle River, New Jersey, United States of America, 682 p.

Schwietering, J.F. 1984, "Beneath the New River gorge", Mountain State Geology, vol. 1984, West Virginia Geological and Economic Survey, Morgantown, West Virginia, United States of America, p. 23-24.

Shepherd, R.G., Pashin, J.C., Greb, S.F. \& Rice, C.L. 1986, "Terrestrial vs. marine depositional model; a new assessment of subsurface Lower Pennsylvanian rocks of southwestern Virginia; discussion and reply modified", Geology (Boulder), vol. 14, no. 9, Geological Society of America, Boulder, Colorado, United States of America, p. 800-802.

Smaldone, D.A., Kite, J.S. \& Hessl, A. 2007, Inventory and Assess Cliff Resources and Visitor Use, Develop and Implement Cliff Management Planning. Unpublished Detailed Implementation Plan, Morgantown, West Virginia, United States of America, $39 \mathrm{p}$.

Spearman, C. 1904, "The proof and measurement of association between two things" American Journal Psychology, vol. 15, no. 1, pp. 72-101

Strachan, B. 2007, Red River Gorge Geology, available at: www.rrgcc.org, accessed on April 6, 2011.

Williams, M. 2010, New River Gorge Rock Climbs, Wolverine Publishing. Silt, Colorado, United States of America, $548 \mathrm{p}$.

Wizevich, M.C. 1992, "Sedimentology of Pennsylvanian quartzose sandstones of the Lee Formation, central Appalachian Basin; fluvial interpretation based on lateral profile analysis", Sedimentary Geology, vol. 78, no. 1-2, Elsevier, Amsterdam, Netherlands, p. 1-45.

Wolf, K. H. and Chilingarian, G V. 1994, eds., Diagenesis, IV. Developments in Sedimentology 51, Elsevier, Amsterdam, Netherlands, 529 p. 
Young, R.W., Wray, Robert A L \& Young, A.R.M. 2009, Sandstone landforms, Cambridge University Press, New York, New York, United States of America, $314 \mathrm{p}$.

Zhu, W., Young, L.Y., Yee, N., Serfes, M., Rhine, E.D. \& Reinfelder, J.R. 2008, "Sulfide-driven arsenic mobilization from arsenopyrite and black shale pyrite", Geochimica et Cosmochimica Acta, vol. 72, no. 21, Elsevier, New York, New York, United States of America, p. 5243-5250. 


\section{Appendix 1: Project Collaborator Clark's (2010) Methodology for Site Selection}

To determine the amount of use each cliff wall (hereby referred to as sector) listed in Williams (2010) climbing guidebook, New River Gorge Rock Climbs, will be assigned a Sector Use Index value (SUI) representing the intensity of use, derived from several variables including the quality of routes present, the quality of neighboring sectors, and the approach time. Within each sector, established climbing routes will be randomly selected based on use where the number of stars assigned to a route will be used as a reference for intensity of use. The number of stars a route is given, which ranges from 0 -4 , indicates both quality and popularity. I will use star values for each climbing route in NERI as determined by Williams (2010), who defines each value as:

4 stars: A world-class route. Unmissable if you climb the grade.

3 stars: A crag classic. A great climb, highly recommended.

2 stars: A good route, worth seeking out if you are in the area.

1 star: An OK route. Worth doing if you are in the area

0 stars: Chossy, mossy, dirty, loose, mis-bolted ... or maybe just a total mystery. Not necessarily a bad route - but probably not the first thing you should jump on when visiting an area.

SUI ranges from 2 to 20 , and is calculated as the following: 
SUI $=\left(\operatorname{LOG}\left(\mathrm{DI} * \mathrm{NI} *\left(\frac{1}{\mathrm{AT}}\right)\right)\right)^{2}$

$D I=$ Desirability Index: a weighted index based on number of starred routes present at a sector, where:

$\mathrm{DI}=(\# 4$ star routes $* 4)+(\# 3$ star routes $* 3)+(\# 2$ star routes $* 2)+(\# 1$ star routes $* 1)+(\# 0$ star routes $* 0.1)$

$N I=$ Neighbor Influence: an index that considers the influence of the two adjacent neighboring sectors. If sectors are located at the end of cliff bands, the adjacent and subsequent neighboring sectors will be used. If sectors do not have any neighboring sectors, they are assigned a value of " 1. ." NI is calculated as:

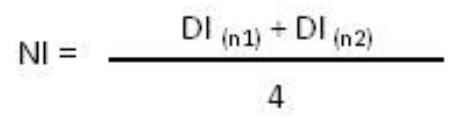

$A T=$ Approach Time: Time in minutes to hike to the sector. Nearby cliffs generally receive more use than those farther away, so AT is inversed so that shorter approach times are more influential on the SUI than longer ones.

To determine a gradient of use, each climbing route will be assigned a Climb Use Index (CUI) index value, which is calculated as: 
$\mathrm{CUI}=(\#$ of stars +1$) *$ sUI

After plots are assigned, the intensity of use will be verified by five local climbers using interviews, questionnaires and focus groups. If they are not representative, another climb will be randomly selected (Appendix: Table 2).

\section{Stratifying Variable Two: Aspect}

Sample plots will also be stratified by aspect to capture varied environmental conditions. In NERI, cliff faces are present on both sides of the canyon rim (north-east, south-west), however only $14 \%$ of established climbing routes are found on the south-western slope of the gorge (north-east facing). To adequately capture environmental conditions, I will weight sites found on the south-western slope by two, so that those comprise roughly $35 \%$ of all samples.

\section{Stratifying Variable Three: Climb Difficulty}

For all climbed plots, level of difficulty will be obtained from the current NERI climbing guidebook, using the YDS scale (Williams 2010). At unclimbed cliffs, angle will be used as an initial reference for difficulty. Less than vertical walls $\left(<75^{\circ}\right)$ frequently include routes of a beginner range (YDS 5.1 - 5.8), vertical walls $\left(75^{\circ}-90^{\circ}\right)$ may include climbs of intermediate ranges (YDS 5.9 -5.11), while overhanging walls $\left(>90^{\circ}\right)$ often contain advanced routes (YDS 5.12-5.14). Relying on my own experience as a climber (10 years experience, advanced 5.13+ climber), my research assistant (11 years experience, advanced $5.13+$ climber) and the local rock climbing guidebook author (13 years 
experience, elite 5.14 climber), we will assign an approximate grade of difficulty to each unclimbed transect based on the YDS. To account for the fractured geometry of the cliffs (e.g., large overhanging roofs), if a roof feature ( $>1.5 \mathrm{~m}$ in depth) is located at the midpoint ( $>51 \%$ of height) or higher on the climb the route will be considered overhanging $\left(>90^{\circ}\right)$, whereas if the roof feature is located lower than the mid-point $(<49 \%)$ the angle of the route will be that of the headwall (most prominent section of wall above roof feature; Appendix: Figures 4 and 5). For overhanging climbing routes, the angle will be calculated as the rise over run between the two measurements. Vertical and less than vertical slab routes will be measured using an angle finder.

\section{$\underline{\text { Additional Variables Considered }}$}

Two climbing styles can predominantly be found in NERI: sport climbing and traditional climbing. Sport climbing uses fixed bolt protection, while traditional climbing uses removable protection to keep the climber safe. Of all NERI routes, $40 \%$ are sport climbs and $60 \%$ are traditional and are relatively evenly distributed between aspects and difficulties. I will not stratify using style, however I will record it for later statistical analysis. Myself, my research assistant, and the local guidebook author will also determine what style of climb each unclimbed transect would be if developed.

\section{Transect Criteria}

All transects must meet predetermined criteria (Larson et al. 2000a, Kuntz \& Larson 2006b), such that they must be a) greater than 15 meters in height, b) without excessive 
amounts of loose rock (for safety; not representative of a climbing route), c) absent of any annual water seeps (not representative of climbing routes), and d) the overall cliff angle must be greater than $60^{\circ}$. Additionally, unclimbed cliffs must a) have no visible presence of use (e.g., climbing chalk, bolts, webbing, associated gear, trails), b) not be listed in any climbing guide books and verified by local climber consensus (Cater 1995, Williams 2010), c) be greater than $7 \mathrm{~m}$ wide, and d) have one climber and the author agree that transects would be suitable for climbing. Variables such as cliff length or distance from human facilities will not be considered when selecting unclimbed sites (Camp \& Knight 1998). 
Appendix 2: Summary of Data Collected in Field with Outcrop Checklist and Schmidt Hammer

\begin{tabular}{|c|c|c|c|c|c|c|c|c|c|c|c|c|c|}
\hline Climb & Cliff & Bolts & Joints & Crossbed & Liesegangen & Corner & Orientation & Height & Hammer & Use & Stars & Surface & Grade \\
\hline The Sword and the Stone & South Nuttall & Anchor & no & no & no & & 80 & 80 & 0 & 3 & 2 & 1 & 12 \\
\hline Wasted Daze & South Nuttall & no & yes & no & no & & 78 & 80 & 0 & 2 & 1 & 1 & 8 \\
\hline Hyperactive & South Nuttall & no & yes & no & no & 180 & 80 & 90 & 0 & 3 & 4 & 1 & 10 \\
\hline Five Ten & South Nuttall & no & yes & no & no & 180 & 84 & 80 & 0 & 1 & 0 & 1 & 8 \\
\hline The Reckoning & South Nuttall & no & yes & no & no & 170 & 85 & 80 & 0 & 2 & 1 & 1 & 11 \\
\hline Guillotine & South_Nuttall & no & yes & no & no & 150 & 78 & 90 & 0 & 2 & 1 & 1 & 10 \\
\hline The Beckoning & South Nuttall & Anchor & yes & no & no & & 180 & 80 & 0 & 3 & 4 & 1 & 12 \\
\hline Unnamed & South_Nuttall & Anchor & yes & no & no & 178 & 58 & 80 & 0 & 3 & 2 & 1 & 7 \\
\hline Pit_Bull Terror & Junkyard Area & no & no & no & yes & & 160 & 80 & 59 & 2 & 1 & 2 & 10 \\
\hline Quaking Flakes & Beauty_Mountain & no & yes & no & no & 80 & 172 & 70 & 56 & 1 & 0 & 1 & 8 \\
\hline Bat_Cave & Endless_Wall & no & yes & no & no & 104 & 16 & 80 & 58 & 2 & 1 & 1 & 8 \\
\hline Just_Another_Glitch & Kaymoor & no & yes & no & yes & 152 & 68 & 70 & 53 & 3 & 1 & 1 & 6 \\
\hline Zag & Bridge_Area & anchor & yes & no & yes & 66 & 164 & 80 & 50 & 4 & 3 & 2 & 8 \\
\hline Route 66 & Endless Wall & no & no & yes & yes & & 142 & 70 & 54 & 1 & 0 & 2 & 11 \\
\hline Square Pegs & Bridge Area & no & yes & no & no & & 182 & 40 & 56 & 2 & 0 & 2 & 11 \\
\hline Gunky Heaven & Bridge_Area & no & yes & yes & yes & 168 & 66 & 60 & 57 & 2 & 1 & 3 & 6 \\
\hline Emergency_Room_Exit & Bubba_City & no & yes & yes & no & 94 & 164 & 60 & 55 & 1 & 0 & 2 & 10 \\
\hline Puppy_Love & Junkyard_Area & no & yes & yes & no & 60 & 160 & 80 & 58 & 1 & 0 & 1 & 10 \\
\hline Stoat_Goes_to_Joshua_Tre & Fern_Buttress & no & yes & no & no & 158 & 60 & 60 & 53 & 1 & 0 & 1 & 7 \\
\hline Crescent_Moon & Endless_Wall & anchor & yes & no & no & 147 & 68 & 70 & 51 & 4 & 3 & 1 & 7 \\
\hline Pleasure and Pain & Fern_Buttress & anchor & no & yes & yes & & 60 & 75 & 53 & 4 & 3 & 2 & 11 \\
\hline Fortitude & Bubba_City & no & no & no & no & & 70 & 40 & 56 & 1 & 0 & 1 & 12 \\
\hline Spams_Across_America & Bridge Area & no & yes & yes & no & 178 & 84 & 50 & 53 & 1 & 0 & 1 & 6 \\
\hline Stigma & Beauty_Mountain & anchor & yes & no & no & & 50 & 50 & 56 & 3 & 1 & 2 & 12 \\
\hline Wham_Bam_Thanks... & Beauty_Mountain & Anchor & yes & yes & no & 60 & 4 & 70 & 56 & 4 & 4 & 1 & 10 \\
\hline Promised & Bridge_Area & anchor & yes & no & no & & 20 & 60 & 61 & 4 & 3 & 2 & 10 \\
\hline State of the Artz & Endless Wall & no & no & no & yes & 16 & 100 & 70 & 58 & 1 & 0 & 1 & 11 \\
\hline Lollipop & Bridge Area & anchor & yes & yes & no & 180 & 80 & 40 & 57 & 3 & 1 & 2 & 7 \\
\hline ***The Good_Old Days & Kaymoor & anchor & yes & no & yes & & 120 & 60 & 55 & 3 & 2 & 1 & 9 \\
\hline Lone_Rhinoceros & Beauty_Mountain & no & yes & yes & no & 70 & 160 & 100 & 57 & 3 & 1 & 1 & 10 \\
\hline Bubba_Down_Under & Bubba_City & anchor & no & yes & no & & 90 & 60 & 54 & 2 & 1 & 2 & 12 \\
\hline New_River_Gunks & Junkyard_Area & anchor & no & yes & yes & & 170 & 60 & 58 & 4 & 3 & 2 & 7 \\
\hline Scream_Seam & Endless_Wall & anchor & yes & yes & yes & 152 & 50 & 40 & 53 & 3 & 2 & 1 & 11 \\
\hline Portly_Gentleman's_Route & Fern_Buttress & anchor & yes & yes & no & 54 & 160 & 65 & 53 & 4 & 3 & 1 & 12 \\
\hline Broken_Foot & Kaymoor & anchor & yes & no & no & & 68 & 60 & 57 & 1 & 0 & 3 & 8 \\
\hline Werewolf & Bubba_City & anchor & yes & yes & no & 160 & 110 & 60 & 51 & 2 & 1 & 2 & 10 \\
\hline The_Tantrum & Kaymoor & yes & no & yes & yes & & 20 & 60 & 57 & 4 & 3 & 1 & 12 \\
\hline The_Green_Piece & Kaymoor & yes & yes & no & yes & 152 & 68 & 70 & 53 & 4 & 3 & 2 & 10 \\
\hline Totally-Clipse & Endless_Wall & yes & no & no & no & & 114 & 70 & 48 & 3 & 2 & 2 & 8 \\
\hline
\end{tabular}




\begin{tabular}{|c|c|c|c|c|c|c|c|c|c|c|c|c|c|}
\hline Climb & Cliff & Bolts & Joints & Crossbed & Liesegangen & Corner & Orientation & Height & Hammer & Use & Stars & Surface & Grade \\
\hline The Chameleon & Fern_Buttress & yes & no & no & no & & 143 & 50 & 52 & 3 & 2 & 2 & 10 \\
\hline Broken Dreams & Beauty Mountain & yes & no & yes & no & 60 & 60 & 70 & 57 & 1 & 0 & 1 & 13 \\
\hline$* * *$ Flight of the Gumbie & Kaymoor & yes & no & no & yes & & 134 & 80 & 53 & 4 & 4 & 2 & 9 \\
\hline Eurobics & Endless_Wall & yes & yes & no & no & & 168 & 80 & 51 & 3 & 1 & 2 & 13 \\
\hline Freaky_Stylee & Endless_Wall & yes & yes & no & no & & 55 & 70 & 0 & 4 & 4 & 2 & 12 \\
\hline The Rubber_Glove Test & Kaymoor & yes & no & no & no & & 128 & 60 & 58 & 2 & 1 & 2 & 12 \\
\hline The Upheaval & Endless Wall & yes & no & no & no & & 120 & 90 & 53 & 4 & 3 & 1 & 9 \\
\hline Canadian Route & Endless Wall & yes & no & yes & no & & 62 & 50 & 50 & 2 & 1 & 3 & 13 \\
\hline Ba_Boschka & Bubba_City & yes & no & no & no & 170 & 60 & 40 & 50 & 2 & 1 & 2 & 11 \\
\hline Wall_Drug & Fern_Buttress & yes & no & no & yes & & 60 & 70 & 53 & 3 & 2 & 2 & 12 \\
\hline Flaming_Asshole_Resistant & Sunshine Buttress & yes & no & no & no & 140 & 60 & 60 & 54 & 2 & 1 & 3 & 9 \\
\hline Sequential Butt Pirates & Endless Wall & yes & yes & no & no & 140 & 64 & 60 & 55 & 3 & 1 & 1 & 12 \\
\hline Dueling_Banjos & Beauty_Mountain & yes & no & yes & no & & 65 & 30 & 50 & 1 & 0 & 1 & 12 \\
\hline Beer Wench & Bubba_City & yes & yes & no & yes & 170 & 110 & 50 & 51 & 2 & 1 & 1 & 8 \\
\hline Discombobulated & Endless Wall & yes & no & yes & yes & & 40 & 90 & 55 & 4 & 3 & 3 & 11 \\
\hline Mango_Boingo & Sunshine_Buttress & yes & no & no & yes & & 20 & 50 & 51 & 2 & 2 & 3 & 12 \\
\hline Skull_Fuck_Direct_Finish & Kaymoor & yes & no & yes & no & & 80 & 70 & 57 & 3 & 2 & 2 & 13 \\
\hline Quinsana_Plus & Endless Wall & yes & yes & no & no & & 152 & 80 & 51 & 4 & 4 & 2 & 13 \\
\hline Freedom Tree & Endless Wall & yes & no & yes & no & & 112 & 110 & 53 & 4 & 3 & 2 & 13 \\
\hline Springer & Kaymoor & yes & yes & no & no & 50 & 160 & 60 & 60 & 3 & 2 & 2 & 10 \\
\hline Slash_and_Burn & Kaymoor & yes & no & yes & no & & 68 & 80 & 55 & 4 & 4 & 3 & 12 \\
\hline Brian'sHouse of Cards & Endless Wall & yes & no & yes & no & & 120 & 90 & 47 & 1 & 0 & 3 & 13 \\
\hline On_a_Wing and a Prayer & Bubba_City & yes & no & yes & no & & 4 & 60 & 57 & 2 & 1 & 2 & 11 \\
\hline Stink Bug & Endless Wall & yes & yes & yes & no & & 60 & 70 & 0 & 2 & 0 & 1 & 12 \\
\hline Out_of the Bag & Kaymoor & yes & no & no & no & & & 80 & 51 & 4 & 4 & 2 & 11 \\
\hline Buzz_Kill & Kaymoor & yes & no & yes & & & 80 & 90 & 56 & 3 & 2 & 2 & 12 \\
\hline First_Steps & Kaymoor & yes & no & no & no & & 80 & 70 & 58 & 4 & 3 & 1 & 10 \\
\hline Unnamed & Sunshine_Buttress & anchor & & & & & & & 0 & 1 & 0 & 1 & 10 \\
\hline
\end{tabular}




\title{
Appendix 3: Method for Schmidt Hammer, used with permission from
}

\section{ASTM}

\author{
Standard Test Method for Determination of Rock Hardness by Rebound Hammer \\ Method1
}

This standard is issued under the fixed designation D 5873; the number immediately following the designation indicates the year of original adoption or, in the case of revision, the year of last revision. A number in parentheses indicates the year of last reapproval. A superscript epsilon (e) indicates an editorial change since the last revision or reapproval.

1. Scope*

1.1 This test method covers the testing apparatus, sampling, test specimen preparation, and testing procedures for determining the rebound hardness number of rock material using as pring-driven steel hammer, referred to variously as a rebound hammer, impact test hammer, or concrete test hammer. 1.2 This test method is best suited for rock material with uniaxial compressive strengths (see Test Method D 7012) ranging between approximately 1 and $100 \mathrm{MPa}$.

1.3 The portable testing apparatus may be used in the laboratory or field to provide a means of rapid assessment of rock hardness or to serve as an indicator of rock hardness.

1.4 The values stated in SI units are to be regarded as the standard.

1.5 This standard does not purport to address all of the safety concerns, if any, associated with its use. It is the responsibility of the user of this standard to establish appropriate safety and health practices and determine the applicability of regulatory limitations prior to use.

2. Referenced Documents

2.1 ASTM Standards: 2

C 805 Test Method for Rebound Number of Hardened Concrete

D 420 Guide to Site Characterization for Engineering, Design, and Construction Purposes

D 653 Terminology Relating to Rock, Soil, and Contained Fluids

D 3740 Practice for Minimum Requirements for Agencies Engaged in the Testing and/or Inspection of Soil and Rock as Used in Engineering Design and Construction

D 4543 Practice for Preparing Rock Core Specimens and Determining Dimensional and Shape Tolerances

D 4879 Guide for Geotechnical Mapping of Large Underground Openings in Rock

D 7012 Test Test Method for Compressive Strength and Elastic Moduli of Intact Rock Core Specimens under Varying States of Stress and Temperatures

2.2 ISRM Standards:

Suggested Method for Determination of Schmidt Rebound Hardness3

Suggested Method for Quantitative Description of Discontinuities in Rock Masses3

3. Terminology

3.1 For common definitions of terms in this standard, refer to Terminology D 653.

3.2 Definitions of Terms Specific to This Standard:

3.2.1 rebound hammer - a portable, spring loaded, pistontype, steel hammer used to classify the hardness of rock in the field or laboratory.

3.2.2 rebound hardness number-HR, a dimensionless number representing empirically determined, relative hardness of rock material or other hard substance by use of a rebound hammer.

4. Significance and Use

4.1 The rebound hardness method provides a means for rapid classification of the hardness of rock during site characterization for engineering, design, and construction purposes (see Guide D 420), geotechnical mapping of large underground openings in rock (see Guide D 4879), or reporting the physical description of rock core (see Practice D 4543). The rebound hardness number, $H r$, can serve in a variety of engineering applications that require characterization of rock material. These applications include, for 
examples, the prediction of penetration rates for tunnel boring machines, determination of rock quality for construction purposes, and prediction of hydraulic erodibility of rock.

4.2 This test method is of limited use on very soft rock or very hard rock (unconfined compressive strengths less than approximately $1 \mathrm{MPa}$ or greater than $100 \mathrm{MPa}$ ).

4.3 The results of this test method are not intended for conversion to strength data suitable for design.

1 This test method is under the jurisdiction of ASTM Committee D18 on Soil and Rock and is the direct responsibility of Subcommittee D18.12 on Rock Mechanics. Current edition approved Nov. 1, 2005.

Published November 2005. Originally approved in 1995. Last previous edition approved in 2005 as D 5873

$-00(2005) \mathrm{e} 1$.

2 For referenced ASTM standards, visit the ASTM website, www.astm.org, or contact ASTM Customer

Service at service@astm.org. For Annual Book of ASTM Standards volume information, refer to the standard's Document Summary page on the ASTM website.

3 Brown, E. T., ed., Suggested Methods: Rock Characterization, Testing, and Monitoring, International

Society of Rock Mechanics: Pergamon Press, London, 1981.

*A Summary of Changes section appears at the end of this standard.

NOTE 1 - Several types of rebound hammers are commercially available to accommodate testing of various sizes and types of concrete construction (See Test Method C 805) and rock material.

NOTE 2-The quality of the result produced by this standard is dependent on the competence of the personnel performing it, and the suitability of the equipment and facilities used. Agencies that meet the criteria of Practice D 3740 are generally considered capable of competent and objective testing and sampling. Users of this standard are cautioned that compliance with Practice D 3740 does not in itself assure reliable results. Reliable results depend on many factors; Practice D 3740 provides a means of evaluating some of those factors.

5. Apparatus

5.1 Rebound Hammer, consisting of a spring-loaded piston, or hammer, which is projected against a metal anvil in contact with the rock surface. The hammer must travel with a fixed and reproducible velocity. The rebound distance of the piston from the steel plunger is measured in a linear scale attached to the frame of the instrument and is taken as an empirical measure of rock hardness.

5.2 Steel Base-A steel base of minimum mass of $20 \mathrm{~kg}$ to which specimens are securely fastened. Rock core specimens may be tested in a steel cradle with a semicylindrical machined slot of the same radius as the core, or firmly seated in a steel V-block, see Suggested Method for Determination of Schmidt Rebound Hardness.

5.3 Calibration Anvil-The standard calibration block used to calibrate the rebound hammer.

5.4 Abrasive Stone - A medium-grained texture silicon carbide or equivalent material.

6. Sampling

6.1 Drill core specimens shall be NX or larger core of at least $15 \mathrm{~cm}$ in length. Block specimens shall have edge lengths of at least $15 \mathrm{~cm}$. Rock surfaces tested in place, including natural outcrops or prepared surfaces such as tunnel walls or floors, shall have a smooth, flat test area at least $15 \mathrm{~cm}$ in diameter. 6.2 Samples shall be representative of the rock to be studied. Obtain samples by direct sampling of subsurface rock units with core borings or by sampling blocks of rock material from

outcrops that correlate with the subsurface rock unit of interest. At surface outcrops, avoid sampling and testing rock material weakened by weathering or alteration or is otherwise unrepresentative of the rock material of interest, see Suggested Method for Quantitative Description of Discontinuities in Rock Masses. 6.3 The rebound hammer is generally unsuitable for very soft or very hard rock. Conduct simple field tests to quickly assess a rock material's suitability for the rebound hammer test

method. Scratch very soft rock with a fingernail and peel with a pocket knife. An intact specimen of very hard rock breaks only by repeated, heavy blows with a geological hammer and cannot be scratched with a common 20d steel nail.

7. Specimen Preparation

7.1 For a block or core specimen, determine its length by taking the average of four lengths measured at four equally spaced points on the circumference and record to the nearest $5 \mathrm{~mm}$.

7.2 For a block or core specimen, determine its diameter by taking the average of two diameters measured at right angles to each other approximately midway along the length of the specimen and record to the nearest $5 \mathrm{~mm}$.

7.3 Report the moisture condition of the block or specimen. 
7.4 The test surface of all specimens, either in the laboratory or in the field, shall be smooth to the touch and free of joints, fractures, or other obvious localized discontinuities to a depth

of at least $6 \mathrm{~cm}$. In situ rock shall be flat and free of surface grit over the area covered by the plunger. If the surface of the test area is heavily textured, grind it smooth with the abrasive stone described in 5.4.

8. Calibration

8.1 Prior to each testing sequence, calibrate the hammer using a calibration test anvil supplied by the manufacturer for that purpose.

8.1.1 Place the calibration anvil in the core holder and conduct ten readings on the anvil.

8.1.2 Calculate the correction factor by dividing the manufacturer's standard hardness value for the anvil by the average of the ten readings taken on the anvil.

NOTE 3-If the instrument reads lower than the manufacturer's standard hardness value, the correction factor will be greater than unity. If the readings are higher, the correction factor will be less than unity.

NOTE 4-Operation of the rebound hammer is satisfactory if the calibration readings fall within the range provided by the manufacturer. If the calibration readings fall outside this range, the instrument must be cleaned, adjusted, or returned to the manufacturer for correction.

NOTE 5-Rebound hammers require periodic servicing and verification to provide reliable results.

9. Procedure

9.1 Place the steel base on a flat, level surface that provides firm, rigid support, such as a concrete floor.

9.2 Securely clamp rock core specimens in a steel cradle with a semicylindrical machined slot of the same radius as the core, or firmly seat into a steel V-shaped block. Securely clamp block specimens to the rigid steel base in such a manner as to prevent vibration and movement of the specimen during the test.

9.3 For tests conducted on specimens in the laboratory, orient the instrument within $5^{\circ}$ of vertical with the bottom of the piston at right angles to and in firm contact with the surface of the test specimen. A guide may be used to ensure the rebound hammer is positioned for optimum performance. Position the hammer not less than one diameter from the edge of the specimen.

9.4 For tests conducted in situ on a rock mass, the rebound hammer can be used at any desired orientation provided the plunger strikes perpendicular to the surface tested. The results are corrected to a horizontal or vertical position using the correction curves provided by the manufacturer.

9.5 Before conducting the tests, ensure the hammer is at the same temperature as the test specimens by exposing it to the ambient environmental conditions of the test area (indoors or outdoors) for at least $2 \mathrm{~h}$. 9.6 Compress the hammer spring by gradually depressing the plunger until the hammer is triggered and impact occurs.

9.7 Read and record the height of the plunger rebound to the nearest whole number, as measured on an arbitrary scale of 10 to 100 divisions located on the side of the hammer, before restoring the piston to its original extension. Repeat this procedure at ten representative locations on the specimen. Test locations shall be separated by at least the diameter of the piston and only one test may be taken at any one point. 9.8 If a specimen breaks during rebound testing, energy is absorbed during breakage and, consequently, the rebound reading will be lower than had it not broken. Any individual impact test that causes cracking or any other visible failure shall cause that test and the specimen to be rejected.

9.9 Some factors that may affect the results of the test include:

9.9.1 Rock at $0^{\circ} \mathrm{C}$ or less may exhibit very high rebound values.

9.9.2 Temperature of the rebound hammer itself may affect the rebound number. The hammer and materials to be tested should be at the same temperature.

9.9.3 For readings to be compared, the direction of impact, horizontal, upward, downward, and so forth, must be the same.

9.9.4 Different hammers of the same nominal design may give rebound numbers differing from one to three units and therefore, tests should be made with the same hammer in order

to compare results. If more than one hammer is to be used, a sufficient number of tests must be made on typical rock surfaces to determine the magnitude of the differences to be expected.

10. Calculation

10.1 Using the data from the ten readings obtained in 9.7, discard readings differing from the average of ten readings by more than seven units and determine the average of the remaining readings. To calculate the rebound hardness number $(H R)$ of the tested rock material, multiply this average by the correction factor determined in 8.1.2 and record the results to the nearest whole number.

11. Report

11.1 Report the following minimum information for each specimen or test area: 
11.1.1 Source of samples, including geographic location; boring number, depth, orientation, and stationing; and rock type,

11.1.2 Weathering and alteration condition of samples, particularly when sampling a surface outcrop, 11.1.3 Type of specimen (core, block, or in situ); size and shape of specimen; and, if block type, whether cut or blasted,

11.1.4 Date of sampling and date of testing,

11.1.5 Storage conditions of samples (for example, exposure to temperature extremes, air drying, and moisture changes),

11.1.6 Type and model number of hammer,

11.1.7 Orientation of the plunger axis during the test,

11.1.8 Method of securing the sample (for example, V-block, or clamps),

11.1.9 Number of tests conducted,

11.1.10 Temperature of site at time of test, and

11.1.11 The individual and average values of hammer rebound, the value of the correction factor, and the rebound hardness number, $H R$ (obtained in 10.1).

12. Precision and Bias

12.1 Precision - No data exist to determine the precision of this test method in determining rock hardness.

12.2 Bias - There is no accepted standard value for $H R$ for any material, therefore bias cannot be

determined.

13. Keywords

13.1 core; hardness; rock mass; rock; unconfined compressive strength

SUMMARY OF CHANGES

In accordance with Committee D18 policy, this section identifies the location of changes to this standard since the last edition $(00(2005))$ that may impact the use of the standard.

(1) Deleted Test Method D 2938 in Sections 1.2 and 2.1, and replaced with Test Method D 7012.

ASTM International takes no position respecting the validity of any patent rights asserted in connection

with any item mentioned in this standard. Users of this standard are expressly advised that determination

of the validity of any such patent rights, and the risk of infringement of such rights, are entirely their own

responsibility. This standard is subject to revision at any time by the responsible technical committee and must be reviewed every five years and if not revised, either reapproved or withdrawn. Your comments are invited either for revision of this standard or for additional standards and should be addressed to ASTM International Headquarters. Your comments will receive careful consideration at a meeting of the responsible technical committee, which you may attend. If you feel that your comments have not received a fair hearing you should make your views known to the ASTM Committee on Standards, at the address shown below. This standard is copyrighted by ASTM International, 100 Barr Harbor Drive, PO Box C700, West Conshohocken, PA 19428-2959, United States. Individual reprints (single or multiple copies) of this standard may be obtained by contacting ASTM at the above address or at 610-832-9585 (phone), 610-8329555 (fax), or service@astm.org (e-mail); or through the ASTM website (www.astm.org).

Copyright by ASTM Int'1 (all rights reserved); Wed Jan 13 13:34:01 EST 2010

Downloaded/printed by Terracon pursuant to License Agreement. No further reproductions authorized. 


\section{KATELYN A. HUFFMAN OLCOTT \\ 108 DRIFTWOOD DRIVE \\ STATE COLLEGE, PA \\ 1-304-610-3334 \\ OLCOTTKAH@GMAIL.COM}

\section{EDUCATION}

POCA HIGH SCHOOL, CLASS OF 2004

- GPA: 4.048 - Class VALEDICTORIAN

WASHINGTON AND LEE UNIVERSITY- CLASS OF 2008

- B.A. ENVIRONMENTAL STUDIES - GPA 3.767

- B.A. GEOLOGY - GPA 3.56

WEST VIRGINIA UNIVERSITY

- M.S. GEOLOGY - GPA 4.0, PENDING GRADUATION IN SPRING 2011

PenNSylvania STATE University

- Ph.D. GEOLOGY - BeginNing MAY 2011

\section{EMPLOYMENT}

Gis AND SCIENTIFIC CONSUlting, SOlE PROPRIETOR, 06/2009-PRESENT

- I CURRENTLY CONSULT SMALL BUSINESSES WHO HAVE MAPPING AND GEOLOGIC CONSULTING NEEDS. MY MOST RECENT CONTRACT WAS WITH PRECISION OIL AND GAS IN BRIDGEPORT, WV.

GRADUATE RESEARCH ASSISTANTSHIP, 05/2010-PRESENT

- I am currently funded by the National Park Service to research the Nuttall SANDSTONE.

GRADUATE TEACHING ASSISTANTSHIP, 3 SEMESTERS

- I WAS IN CHARGE OF TEACHING INTRODUCTORY GEOLOGY LABS AT WVU.

Triana Management Services, Charleston, WV, 06/2008-06/2009, GEOLOGIST/ENVIRONMENTAL SCIENTIST

- I WAs an EXPLORATION geologist and I WORKED With a team to find Places to DRILL FOR NATURAL GAS IN THE APPALACHIAN BASIN. I ALSO DREW FROM MY ENVIRONMENTAL SCIENCE DEGREE TO ADVISE ON INVESTMENT OPPORTUNITIES.

BUREAU OF LAND MANAGEMENT - USDOI, WASHINGTON, DC, 06/2007-06/2008, NATURAL RESOURCE/GIS SPECIALIST

- I WAS RESPONSIBLE For USING gIS to ANALyze NATURAL RESOURCES ON PUBLIC LAND. I ALSO MADE MAPS AND MANAGED THE NATIONAL LANDSCAPE CONSERVATION SYSTEM'S GEOSPATIAL INFORMATION. I HAD TO WORK WITH OTHER SCIENTISTS TO MAKE COHESIVE SCIENTIFIC INVESTIGATIONS, ONE OF WHICH WAS PUBLISHED.

WASHINGTON AND LEE'S OUTING CLUB, LEXINGTON, VA, 06/2007-09/2007, CO-DIRECTOR OF PRE-ORIENTATION PROGRAM

- I WAS RESPONSIBLE FOR ORGANIZING THE PRE-ORIENTATION BACK-PACKING PROGRAM FOR INCOMING FRESHMAN.

WASHINGTON AND LEE UNIVERSITY, LEXINGTON, VA, 08/2006-01/2008, TUTOR

- I TUTORED OTHER GEOLOGy STUDENTS WHO WERE STRUGgLiNG WiTH THEIR COURSES.

WOOd'S CREEL MONTESSORI, LeXington, VA, 06/2006-08/2006, SUMMER CAMP CURRICULUM DIRECTOR

- I WAS RESPONSIBLE FOR CREATING SUMMER CAMP CURRICULUM FOR 3-6 YEAR OLD CHILDREN. I DREW HEAVILY ON MY BACKGROUND IN GEOLOGY AND ENVIRONMENTAL STUDIES. I WAS ALSO IN CHARGE OF A CLASSROOM OF 20 3-6 YEAR OLD CHILDREN

WASHINGTON AND LEE UNIVERSITY, LEXINGTON, VA, 06/2005-08/2005, RE LEE

FELLOW/STUDENT RESEARCHER 
- I PERFORMED RESEARCH WITH A PROFESSOR THAT WE LATER PRESENTED AT A NATIONAL CONFERENCE.

Applebee's Restaurant, Lexington, VA, 1 2/2004 - 02/2005, SERVER

- I WAS RESPONSIBLE FOR WAITING ON TABLES AND GREETING CUSTOMERS.

CRAcker BARREL Restaurant, Cross lanes, WV, 1 2/2003-12/2004, SERVER

- I WAS RESPONSIBLE FOR WAITING ON TABLES AND GREETING CUSTOMERS.

TEEN INSTitute, ChARLEston, WV, 07/2003 - 07/2004, INTERN

- I WAS RESPONSIBLE FOR HELPING RUN A CAMP FOR AT RISK TEENAGERS. I WAS INVOLVED AS A VOLUNTEER FOR THE SAME GROUP FOR FOUR YEARS.

LAW OfFice of Rosalee JuBA-PLuMLey, ELEANOR, WV, 08/2003-07/2004, INTERN

- I WAS RESPONSIBLE FOR FILING, RESEARCHING, AND ANSWERING THE PHONE.

SKILLS

- PETREL

- GIS - ARCGIS

- Remote Sensing - er Mapper

- Experience With Geophysical SURVEy EQuiPMENT

- PROGRAMMING - PYTHON

- Website DeVElopment - HTML

- GEOGRAPHIX

- GENEsis

- R statistical package

- MOdFLOW

- AQTESOLV

- MicRosoft OfFICE

- PROFICIENT IN GERMAN

Publications AND PREsentations

- FOR ROCK CLIMBING, NOT ALL SANDSTONES ARE CREATED EQUAL; AN ANALYSIS OF THE NUTTALL SANDSTONE, NEW RIVER GORGE, WV, ABSTRACT ACCEPTED FOR TALK AT GSA 2010 , PRIMARY AUtHOR, DENVER, CO

- Conservation significance of america's Newest system of protected areas: National Landscape Conservation System, Publishied in Natural areas JOURNAL, SECOND AUTHOR, JANUARY 2009

- GEOPHYSICAL INVESTIGATION OF THE SOUTH RIVER FLOODPLAIN, BUENA VISTA, VIRGINIA, Primary Author, POSTER giVen AT SEgSA 2006, KNOXVILLE, TN

- BATHERS CAVE REVISITED: CLIMATIC INTERPRETATION USING GEOCHEMISTRY, SEDIMENTOLOGY AND LUMINESCENCE DATING, SECOND Author, ABstract, GSA 2006, Philadelphia, PA

- BATHERS CAVE REVISITED: CLIMATIC INTERPRETATION USING GEOCHEMISTRY, SEDIMENTOLOGY AND LUMINESCENCE DATING, PRIMARY Author, POSTER GIVEN AT SCIENCE, SOCIETY AND THE ARTS, W\&L UNIVERSITY, 2007

- MONTESSORi METHOd AND THE Foundations of AN ENVIRONMENTAL ETHIC IN EARLY EDUCATION AT WOOdS CREEK MONTESSORI, TALK GIVEN AT SCIENCE, SOCIETY AND the ARts, Primary Author, W\&L UNIVERsity, 2007 
- graduate student Research committee grant, WVu department of geology

- Roy sites Memorial Scholarship, WVu department of Geology

- graduate Research assistantship, National park Service, Summer and fall 2010

- graduate teaching assistantship, fall 2009 and Spring 2010

- Celebrating Student Success Award, 2008 - one of 10 students Who Received THIS HONOR FOR CONTRIBUTING TO THE UNIVERSITY IN A POSITIVE WAY THROUGH EXTRACURRICULAR CLUBS AND ACTIVITIES

- J.edgar lewis honor Scholarship to Washington and Lee UNiversity, Worth APPROXIMATELY $\$ 160,000$

- gates EnVironmental Award - given to one senior eVery year who CONTRIBUTES THE MOST TO CAMPUS SUSTAINABILITY

- Outing Club environmental AWARd - given to one member Who contributes THE MOST TO ENVIRONMENTAL CAUSES ON CAMPUS

- Geology Department Scholarship, 2005

- HONOR ROLL AND DEAN'S LIST, 2006-2008

- Nominated as peer tutor

- R.E. LEe Research GRANT Recipient

\section{Clubs ANd Extracurricular Activities}

- Sigma gamma Epsilon geology honor Society, Vice President

- geologic society of america

- Youth For Understanding, Volunteer and host parent

- Student EnVironmental action league, fundraising Chair

- outing Club, Key Staff for Spelunking, head Sherpa

- geological society of america

- Boxerwood gardens Volunteer

- Pi Beta Phi fraternity for Women, Leadership and Nominating CommitTee

- Hugh O'Brian Youth Leadership, COMMUNITy SERVICE DiRector

- West Virginia Democratic party Volunteer 